\title{
ART REQUIEM: UM ANTI-POEMA DADA DIGITAL PARA O OCASO DA ARTE CASUAL**
}

Autor: Acaso através de Antonio Miguel

Palavras-chaves: manifestos dada; acaso; anti-poema digital

\section{Anti-Resumo}

Este anti-resumo diz do anti-poema que aqui se apresenta que ele não tem como propósito convencer ou induzir os leitores a quaisquer teses acerca de possíveis conexões entre literatura, matemática e educação. Este anti-poema sem conteúdo, lógica, enredo ou propósito também não problematiza nada e nem reivindica autoria, originalidade ou cientificidade. Se autor houver que, com certeza, possa reivindicar tais atributos, ele não é outro senão o acaso, o imprevisivel. Este anti-poema que não contém partes é constituído de duas partes. Na primeira - que antecede mas também se inclui na segunda -, apresenta-se ao leitor este anti-resumo da segunda. Na segunda parte, inspirando-se talvez-pois nunca se pode dizer com certeza - na leitura dos Sete Manifestos Dada de Tristan Tzara, bem como no processo de confecção de uma colcha de retalhos vistos como enxertos remissivos citacionais à semelhança das colagens de Kurt Schwitters (1887-1948) e Hans Arp (1886-1966) -, o acaso inventa e apresenta um anti-poema pastiche que, por acaso, acabou assumindo a forma de um antipoema manifestamente dada. Este anti-poema se apresenta terapeuticamente sob a forma de caixas de textos ou imagens espalhadas aleatoriamente ao longo das próximas 14 páginas desta revista digital que, talvez, não por acaso-pois nunca se pode dizer com certeza-, decidiu publicá-lo. Ah, desculpem -me! Eu estava quase me esquecendo de dizer. O anti-poema de duas partes que este anti-resumo não resume tem também uma terceira parte: um anti-posfácio que sucede mas também se inclui nas outras duas partes que o antecedem. Na terceira parte - agora eu, e não mais o acaso - faço referências e, às vezes, esclarecimentos às citações textuais ou imagéticas contidas nas caixas de textos on imagens aleatoriamente numeradas para indicar fontes e autorias, satisfazendo, assim, o ego dos que ainda insistem em reivindicá-las ou de obrigar-nos a citá-las, ainda que poetas não citem as suas fontes ou as atribuam, todas, às musas. $\mathrm{O}$ acaso então proporciona a vocês, leitores e leitoras, a chance de se envolverem com uma experiência de leitura terapêutica de um texto produzido de um modo bem diferente dos usuais e, sobretudo, muito diferente de um texto regrado e argumentativo característico do mundo acadêmico. Proponho que vocês o leiam aleatoriamente - e, portanto, na ordem segundo a qual vocês decidam percorrer as suas páginas e, cada página, na ordem segundo a qual vocês decidam percorrer as caixas de textos ou imagens - como se cada uma de suas páginas fosse uma página de um site qualquer da internet. Proponho, então, que vocês o leiam como se ele fosse um hipertexto em que as notas funcionam como placas de sinalização - mas nunca de interpretação ou análise - da leitura terapêutico-casual que fiz dos Sete Manifestos Dada de Tristan Tzara. Ao assim procederem, consentindo que as mãos do acaso lhes afetem conduzindo-lhes em suas leituras personalizadas do texto, vocês estarão também realizando, com certęa, outras leituras

\footnotetext{
* DOI - 10.29388/978-65-86678-51-2-0-f.337-388
} 
autoterapêuticas dos Manifestos. Quero finalmente lhes dizer que o acaso me levou a oferecer este anti-poema réquiem a todos os mortos da Primeira Guerra Mundial, bem como, talvezpois nunca se pode dizer com certeza -, a todos os mortos por vir de outras guerras à vista ou que estão sendo ou serão travadas em planos de invisibilidade, de silêncio, de imperceptibilidade. Ofereço também este anti-poema elegíaco casual a Tristan Tzara e a todos os artistas e escritores que ecoando, de uma outra maneira, os gritos inaudíveis de outros incontáveis artistas-vítimas ou desertores da Primeira Guerra Mundial, decidiram inaugurar em 1916, em Zurique, o Cabaret Voltaire.

\begin{abstract}
Irene viaja à distante Epidauro, consulta Esculápio em seu templo e o indaga a respeito dos males que a acometem. Começa por queixar-se de cansaço e fadiga; o deus dedara que isso se deve ao longo caminho que percorrera. Ela diz não sentir mais fome à noite; o oráculo ordena-lhe que coma menos no almoço. Ela acrescenta que tem insônias; ele prescreve que só se deite à noite. Ela pergunta por que se sente pesada, e qual o remédio para isso; o oráculo responde que ela deve se levantar antes do meio-dia, e caminhar para exercitar as pernas. Ela declara que o vinho lhe faz mal, o oráculo diz-lhe que beba água; que tem indigestōes, e ele recomenda que faça dieta. Minha vista é fraca, diz Irene; use óculos, diz Esculápio. Estou enfraquecida, não sou forte como outrora, nem saudável como costumava ser; isso porque, diz o deus, você está envelhecendo. E qual o meio para sanar esta apatia? o mais curto, Irene, é morrer, como fizeram sua mảe e sua avó. LBa9
\end{abstract}

1. Pegue um jornal

2. Pegue a tesoura

3. Escolha no jornal um artigo do tamanho que vocế deseja dar a seu poema

4. Recorte 0 artigo

5. Recorte em seguida com atenção algumas palavras que formam esse artigo e meta-as num saco

6. Agite com cuidado

7. Seguidamente, retire os

8. recortes um por um

conscienciosamente segundo a ordem pela qual eles foram saindo do saco

9. O poema se parecerá com você

10. E você tornou-se um escritor infinitamente original e de uma sensibilidade encantadora, ainda que incompreendida pelo vulgo TTZ42

- verdadeiro pensador religioso é como um EQUILIBRISTA que dança sobre a corda. Ele caminha, aparentemente, quase que apenas sobre $o$ ar. Sua base é a mais estreita que se pode pensar. E, contudo, ele caminha realmente sobre ela. LW4108

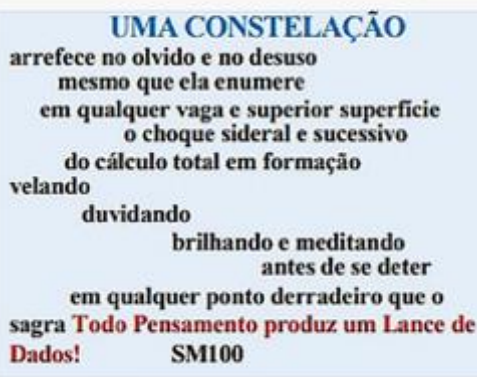

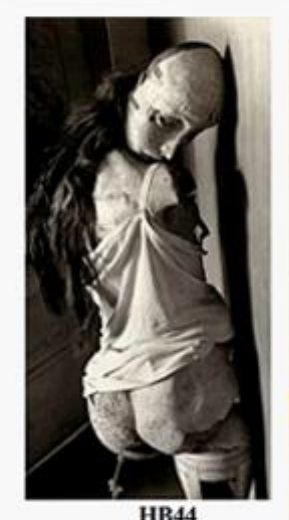

HB44
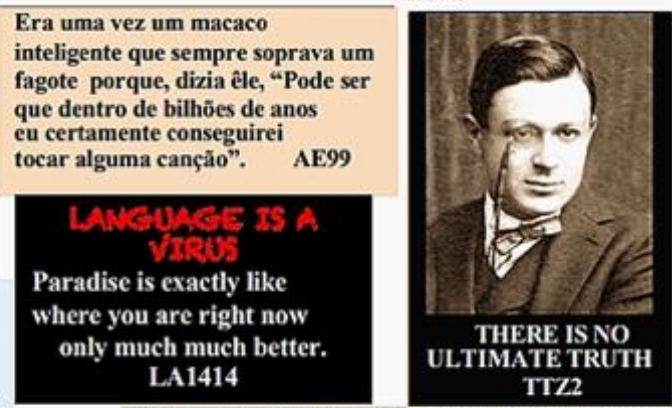

Da vontade de um homem depende a preparação de grandes ousadias e tentativas complexas para a elevação e melhoria para colocar um termo ao horrivel DOMínIO DO ABSURO E DO ACASO que até agora tem sido chamado de história. FN500
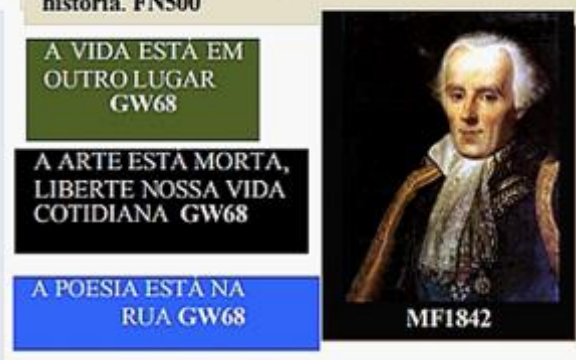
Merriam-Webster @ M-W.com: Middle English, from Anglo-French HASARD, from Old Spanish AZAR, from Arabic AL-ZAHR the die. First Known Use in English: 14th century.

Concise OED@ OxfordDictionaries.com: Middle English: from Old French HASARD, from Spanish AZAR, from Arabic AZ-ZAHR 'CHANCE, LUCK', from Persian zăr or Turkish ZAR 'DICE'. Collins English @ Dictionary.com: Century13 English: from Old French HASARD, from Arabic AZ-ZAHR THE DIE. Random House @ Dictionary.com: 1250-1300; ME HASARD < OF, perh. < AR AL-ZAHR THE DIE. Webster's New World @ YourDictionary.com: ME < OFr HASARD, GAME OF DICE, adventure < ? AR AZ-ZAHR, for Egypt colloq. AR ALZAHR, DICE. American Heritage @ YourDictionary.com: HASARD, DICE GAME, from Old French, possibly from Old Spanish AZAR, possibly from Arabic AZ-ZAHR, the GAMING DIE: al-, the + zahr, GAMING DIE. Chambers Dict@Chambers.co.uk: 13c: from French HASARD.

EHL70

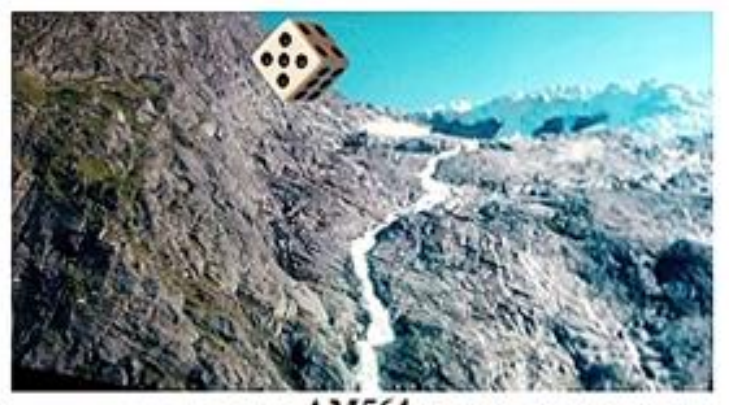

AM564

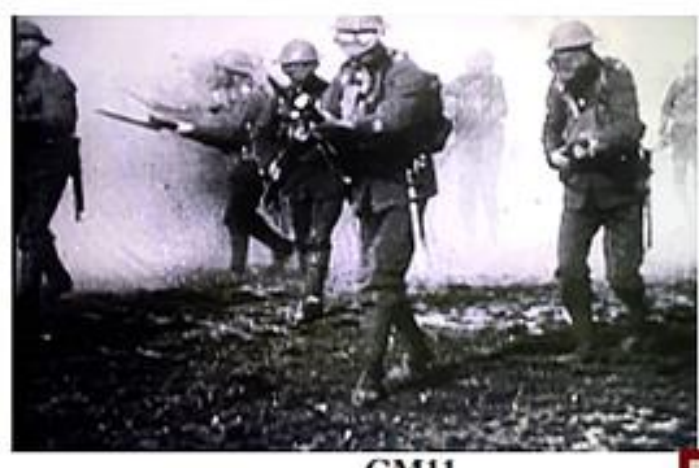

GM11

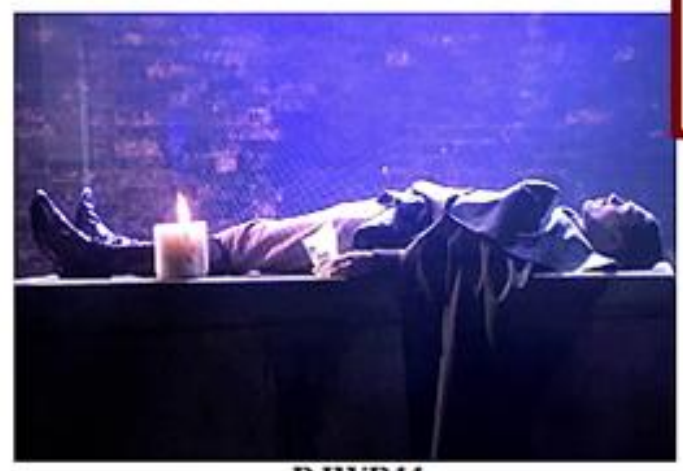

DJWR11

TODA
REVOLUCĀO
É UM LANCE
DE DADOS
JM09

De tudo há saciedade: de sono, de amor, de doce música e de dança impecável: espera-se apaziguar o desejo muito mais dessas coisas QUE DA GUERRA. HCW13

O que quero ensinar é: passar de um SEM SENTIDO NÃO ÓBVIO para um SEM SENTIDO ÓBVIO. LW464

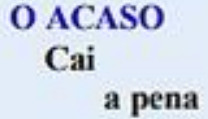

para afundar-se na

espuma original recente de onde

seu delírio e X L o D e até ao cimo desvanecido pela neutralidade idêntica do abismo SM7050

cabaret voltaire wit wat.

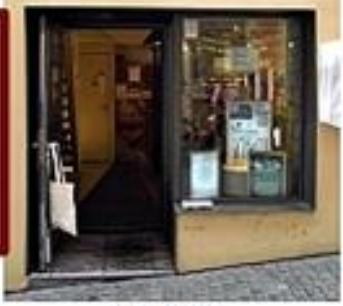

CV1916

Ele falava nisso todo dia Se morresse ainda forte, um bom seguro era uma sorte pra familia: A LOTERIA! GG666

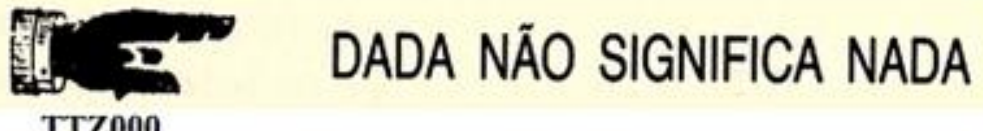




\section{ESSAI PHILOSOPHIQUE}

sta

\section{LES PROBABILITÉ;}

\author{
PAs M. LE COMTE'LAPLACE,
}

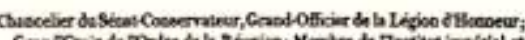

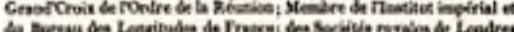

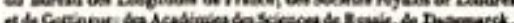

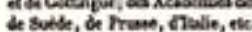

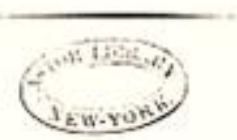

PARIS,

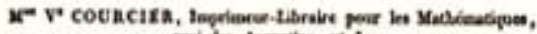

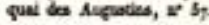
18,6. *

\section{PL12}

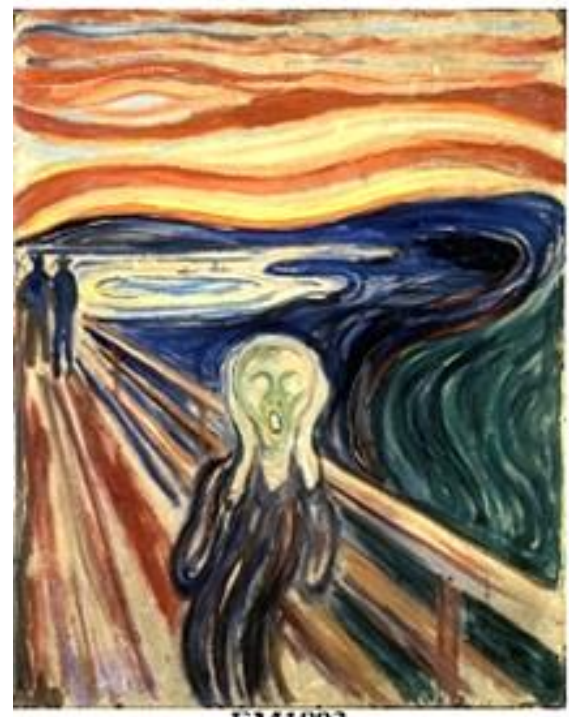

EM1893

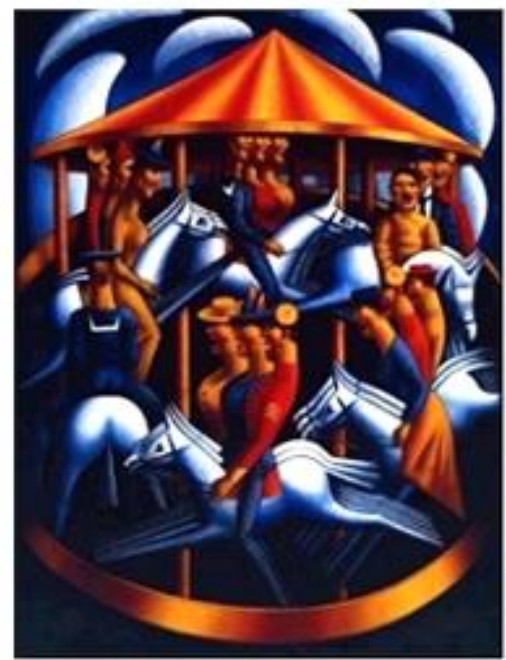

MG1916
Este Ensaio filosófico é o desenvolvimento de uma aula sobre as probabilidades, que eu dei em 1795 , na Ecole Normale, onde eu era professor, e que foi publicada no Jornal de Ciências daquela escola. Depois, eu também discuti esse mesmo tema em uma obra denominada Teoria analítica sobre as probabilidades. Na presente obra, eu exponho, sem recorrer à Análise, os principios e resultados gerais dessa teoria; e os aplico a importantes questões da vida, que não são, com efeito, para a maior parte das pessoas, senão problemas de probabilidade. Mesmo considerando os princípios eternos da razão, da justiça e da humanidade, veremos que há uma grande vantagem em seguir as probabilidades associadas a tais problemas, e graves inconvenientes em se descartá-las: estas probabilidades, como aqueles que se beneficiam das loterias, acabam sempre por prevalecer em meio às oscilações do acaso. PL76

Hino para a juventude morta

Que sinos soam por esses que como gado morrem? Apenas a ruidosa raiva monstruosa das armas. Apenas os estampidos velozes e pulsantes de rifles gaguejantes podem recitar as suas fúnebres preces apressadas. Que velas velozes poderão manter- se acesas para transportar seus corpos? Não nas mãos dos meninos, mas em seus olhos, resplandecerão os piedosos reflexos de despedidas. Seus brancos mantos mortuários serão semblantes pálidos de meninas. Suas flores, a ternura de lembranças silenciosas. E cada crepúsculo lento, uma familia em luto WO4433.

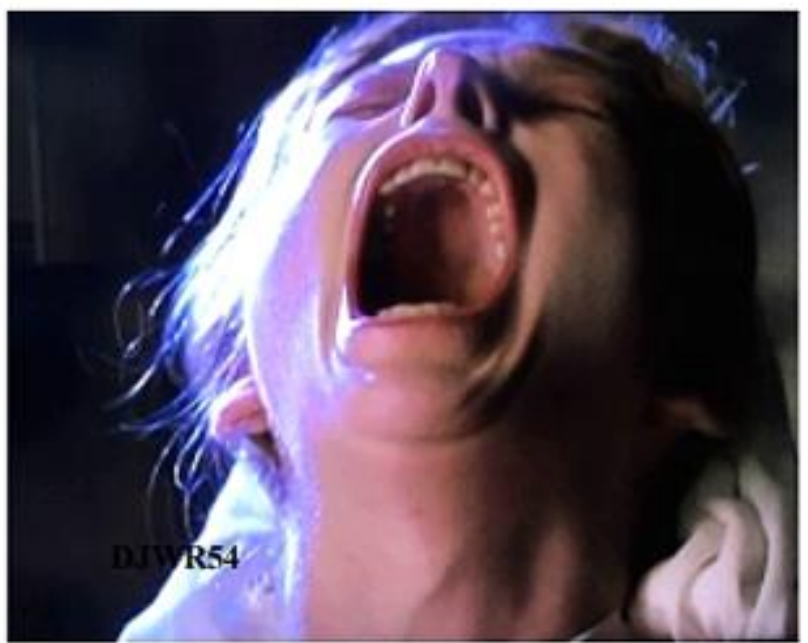

ESCREVO UM MANIFESTO E SOU POR

PRINCIPIO CONTRA OS MANIFESTOS, TAL COMO SOU CONTRA OS PRINCIPIOS. TTZ 2233

\section{DADA NÃO} SIGNIFICA NADA!

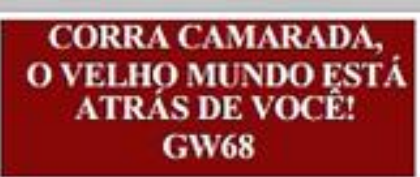


Uma inteligência que, em um instante dado, conhecesse todas as forças que animam a natureza e todas as posições de todos os seres que a compõem, compreenderia numa única fórmula os movimentos dos maiores corpos e dos menores átomos do universo; para tal inteligência NADA SERIA INCERTO, e o futuro, assim como o passado, estaria presente perante os seus olhos. PL60

Denominam-se Instituições de previdência as que fazem contratos de seguros de vida ou de bens, e mesmo de auxilios mútuos no caso de enfermidade ou de invalidez, tais como as companhias de seguros de vida, as companhias de seguros terrestres e marítimos, os montepios, as associações de auxilios mútuos, as beneficências etc. As pessoas que realizam contrato com as companhias de seguros cedem às mesmas uma certa quantia, denominada prêmio. As instituições de prêmio fixo estabelecem suas tabelas de acordo com - cálculo de probabilidades, de modo a ficarem habilitadas a indenizar os segurados e aobter lucros para seus acionistas. CFP33

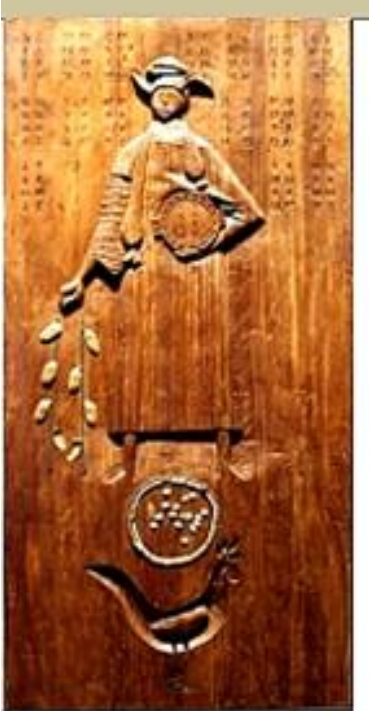

$$
\text { OI31 }
$$

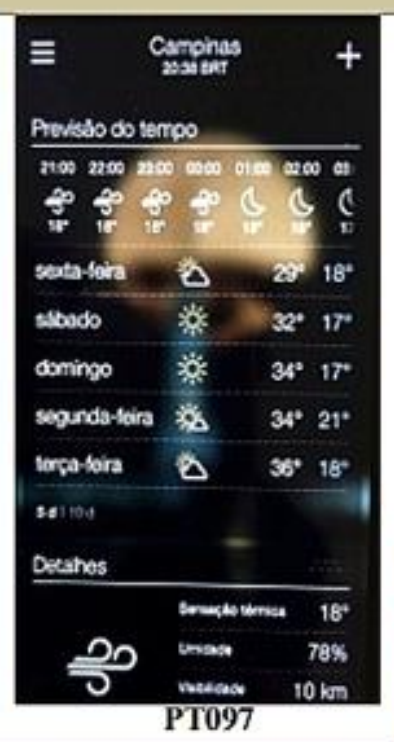

A TEORIA DO ACASO consiste em reduzir todos os acontecimentos do mesmo gênero a um certo número igualmente possível de casos, de modo que nós fiquemos igualmente indecisos sobre a existência de tais casos; e em determinar - número de casos favoráveis ao acontecimento cuja probabilidade desejamos determinar. A relaçäo entre este último número e aquele de todos os casos possiveis é a MEDIDA DESTA PROBABILIDADE, a qual não é senão uma fração cujo numerador é o número de casos favoráveis e cujo denominador é o número de todos os casos possíveis. PL55

Ele falava nisso todo dia. Quem sabe lá o que aconteceria? A incerteza, a pobreza, a má sorte o seguro de vida, o pecúlio. Era preciso toda a garantia. Se a mulher chora o corpo do marido, o seguro de vida, o pecúlio darāo a certeza do dever cumprido. GG666

A magia e a vida. Tínhamos a relação e a distribuição dos bens físicos, morais e honoríficos. E sabiamos transpor o mistério e a morte com o auxilio de algumas formas gramaticais. Só não há determinismo onde há mistério. Mas que temos nós com isso? A alegria é a PROVA DOS NOVE!

OA77

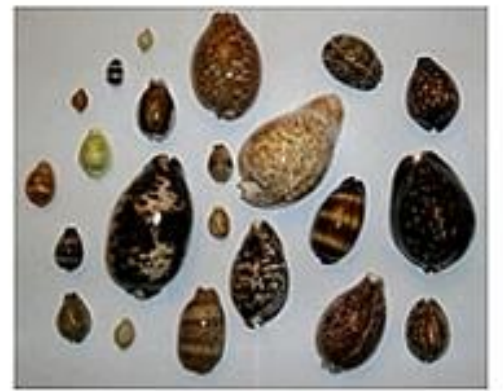

BZ256

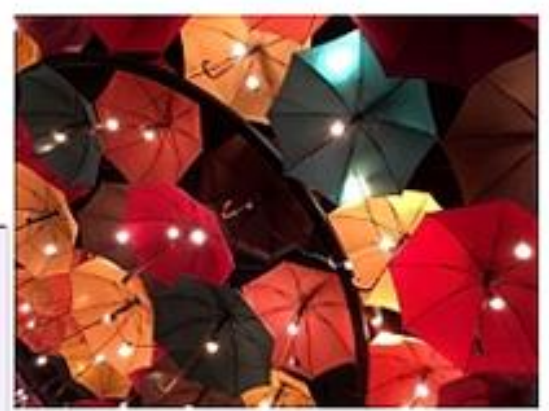

GC660

A magia de uma palavra - DADA que pôs os jornalistas diante da porta dum MUNDO IMPREVISTO, não tem para nós importância nenhuma. MD1918

O diretor de uma compania de seguros de vida ignora quando morrerá cada um de seus assegurados, mas se baseia no cálculo de probabilidades e na lei dos grandes números, e não se equivoca, posto que distribui dividendos a seus acionistas. Estes dividendos não se evaporariam se, uma vez subscritas as apólices, um médico extremamente perspicaz e indiscreto investigasse $\mathrm{e}$ informasse $\mathrm{o}$ diretor sobre as mortes de seus assegurados. Este médico dissiparia a ignorância do diretor, mas näo influiria sobre os dividendos, que, evidentemente, não são um produto desta ignorância. HP40 
Tabela de mortalidade - Denomina-se tabela de mortalidade um quadro que indica qual é, em cada idade, o número provível de óbitos durante o ano que começa. As tabelas usadas são propriamente de sobrevivência ou de vitalidade, que consistem num quadro que indica o número de sobreviventes, em cada idade, para um certo número de crianças nascidas no mesmo ano. CFP89

LEIS DA NATUREZA são axiomas ou regras gerais de movimento e repouso observadas pelos corpos naturais, na ação que exercem uns sobre os outros e nas modificações que incidem em seu estado natural. [... Há autores que dão o nome de leis do movimento às leis particulares do movimento e chamam de LEIS DA NATUREZA as leis mais gerais e mais extensas que sĩo como axiomas das quais as outras são deduzidas. JLRD77

Tendo agora (NÃO SEI POR QUE ACASO) engajado meus pensamentos nas CONTAS DE MORTALIDADE, consegui, até agora, reduzir vários VOLUMES grandes e confusos $\mathrm{em}$ algumas TABELAS PERSPICUAS, e também, ABREVIAR tais OBSERVAÇÕES, do modo como naturalmente fluiam das tabelas, para alguns PARAGRAFOS SUCINTOS, sem longas séries de deduçōes retóricas... JG1662

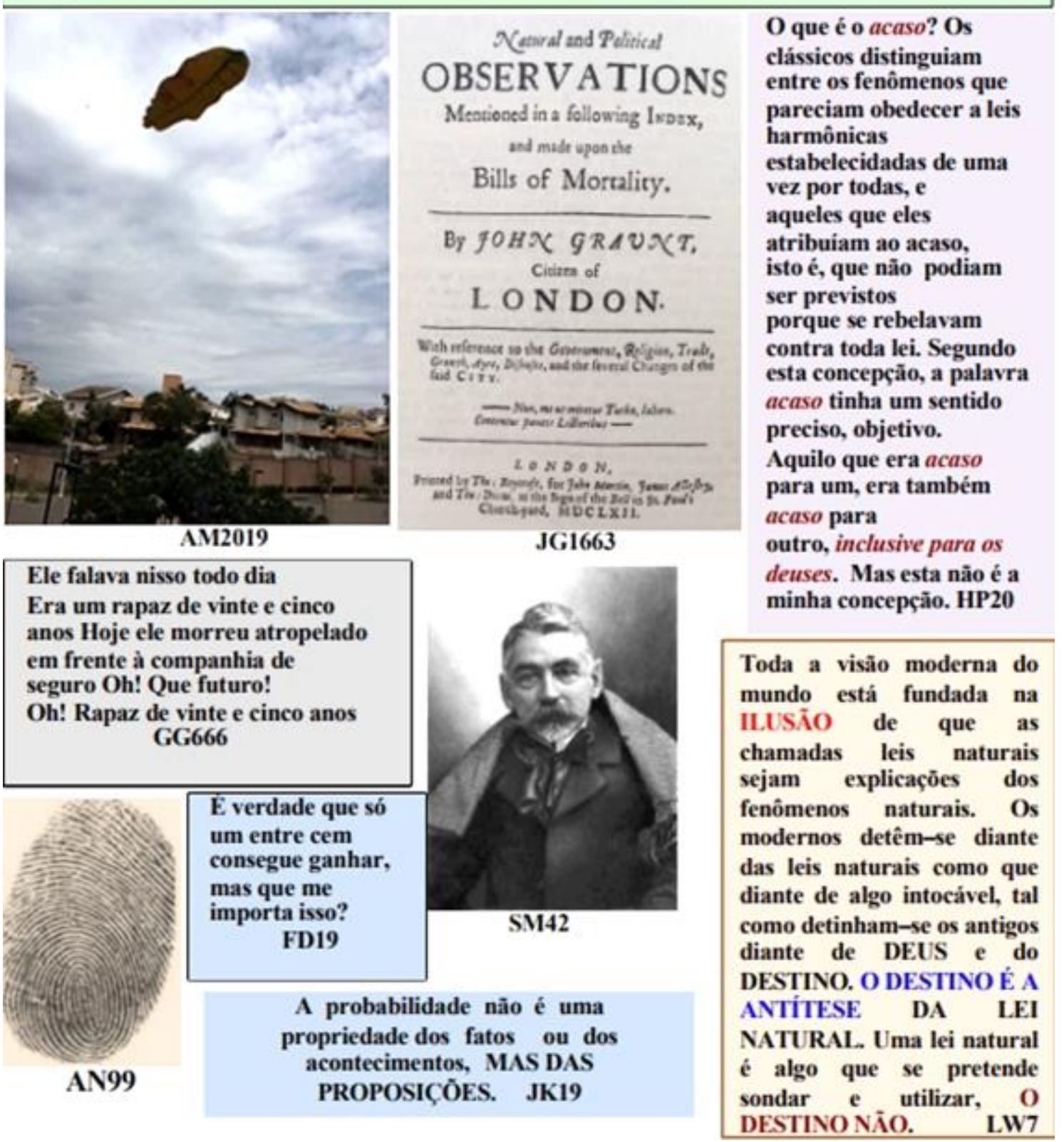


Não sou NEM a favor e NEM contra; $E$ NÃO EXPLICO, porque odeio o bom senso. DADA : eis uma palavra que leva as ideias à caça: cada burguês é um dramaturgozinho que procura as causas ou os fins (segundo o método psicanalítico que praticar) para cimentar a intriga, história que fala e que se define. Cada espectador é um intriguista logo que tenta explicar uma palavra (conhecer!).

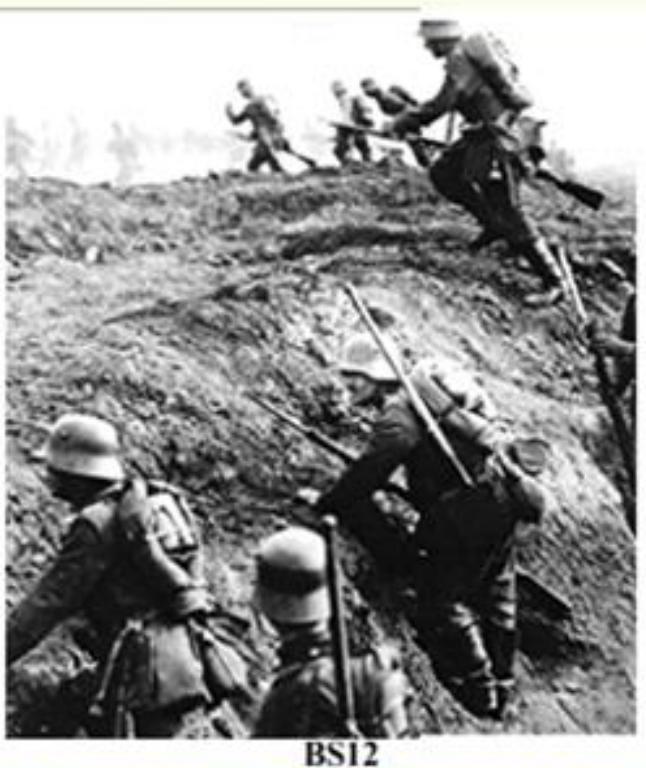

A REVOLUCAO DEVE OCORRER NOS HOMENS ANTES DE OCORRER NAS COISAS GW68

A teoria das probabilidades não é senão a ciência da lógica tratada quantitativamente CSP67
TTZ20

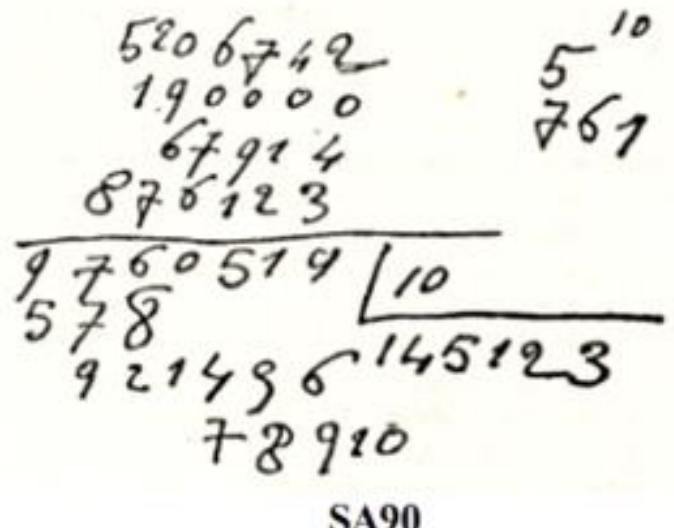

Só podemos atender ao mundo ORECULAR. Somos concretistas.

Nós consideramos as ideias, reagimos.

Queimamos gente nas praças públicas. Nunca admitimos o nascimento da lógica. Pelos roteiros. Acreditar nos sinais. Acreditar nos instrumentos e nas estrelas. A ALEGRIA É A PROVA DOS NOVE! OA822

\section{SILOGISMO COLONIAL}

TTZ943

Ninguém consegue escapar ao DESTINO.

Ninguém consegue escapar a DADA.

DADA thes pode fazer escapar ao DESTINO. Só

Você me deve 943,50 Francos

Perguntei a um homem o que era o Direito.

Ele me respondeu que era a GARANTIA DO

EXERCICIO DA POSSIBILIDADE.

Esse homem chamava-se Galli Mathias. COMI-O!

\section{A EXATIDĀO É UMA} FRAUDE! AW4

\section{MA77}

Arranquei esta tirana do bojo do violào.

A sorte é uma cigana que escreveu na minha mão.

No meio dos seus rabiscos, só duas coisa eu entendo: correr mundo correr risco e o resto é seguir vivendo.

Meu coração é um alazão passarinheiro, sem freio nem ferradura, riscando casco no vento. Só por paixão ele galopa assim ligeiro, pois empaca que nem mula diante do sofrimento. JGP442 
Greatest and Least Yearly Numbers of Burials and Christenings in Romsey

\begin{tabular}{|c|c|c|c|c|c|c|}
\hline \multirow[b]{2}{*}{ Dicant } & \multicolumn{3}{|c|}{ aurials } & \multicolumn{3}{|c|}{ CHEISTENINGS } \\
\hline & MAXMUM & MiNaMU/M & RATO & Maximts & MiNimus & eAtio \\
\hline $1569-1578$ & 66 & 34 & 19 & 70 & $s_{0}$ & 1.4 \\
\hline 15791588 & 87 & 39 & 22 & 90 & 45 & 20 \\
\hline $1589-1598$ & 117 & 38 & 3.1 & 71 & 52 & 1.4 \\
\hline $1599-1608$ & 53 & 30 & 18 & 93 & 60 & 1.6 \\
\hline $1609-1618$ & 116 & 51 & 2.3 & 87 & 61 & 1.4 \\
\hline $1619-1628$ & 89 & 50 & 1.8 & 85 & 63 & 1.4 \\
\hline $1629-1638$ & 156 & 35 & 4.5 & 103 & 66 & 1.6 \\
\hline $1639-1648$ & 137 & 46 & 3.0 & 87 & 62 & 1.4 \\
\hline $1649-1658$ & 80 & 28 & 2.9 & 86 & 52 & 1.7 \\
\hline
\end{tabular}

A ciência preditiva pode recolher estatísticas e fazer gráficos. Mas suas predições, como muito tem se tem dito, não são senão um retorno à história já passada. JD2001

Quem já ouviu uma mesma coisa relatada por 12000 testemunhos oculares tem apenas 12000 probabilidades, o que equivale a uma forte probabilidade que dista muito da certeza. FMA94

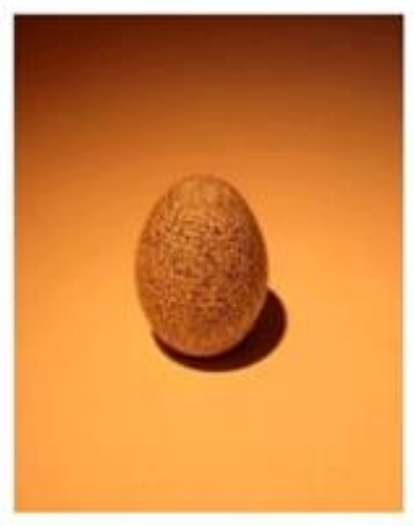

Não há progresso na arte, mais do que existe progresso em fazer amor. Existem simplesmente diferentes maneiras de fazê-los. MR65

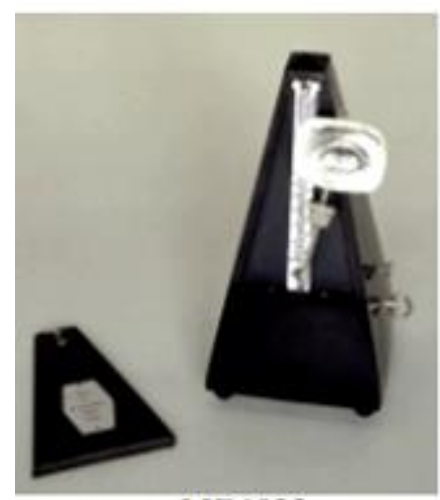

MR1923
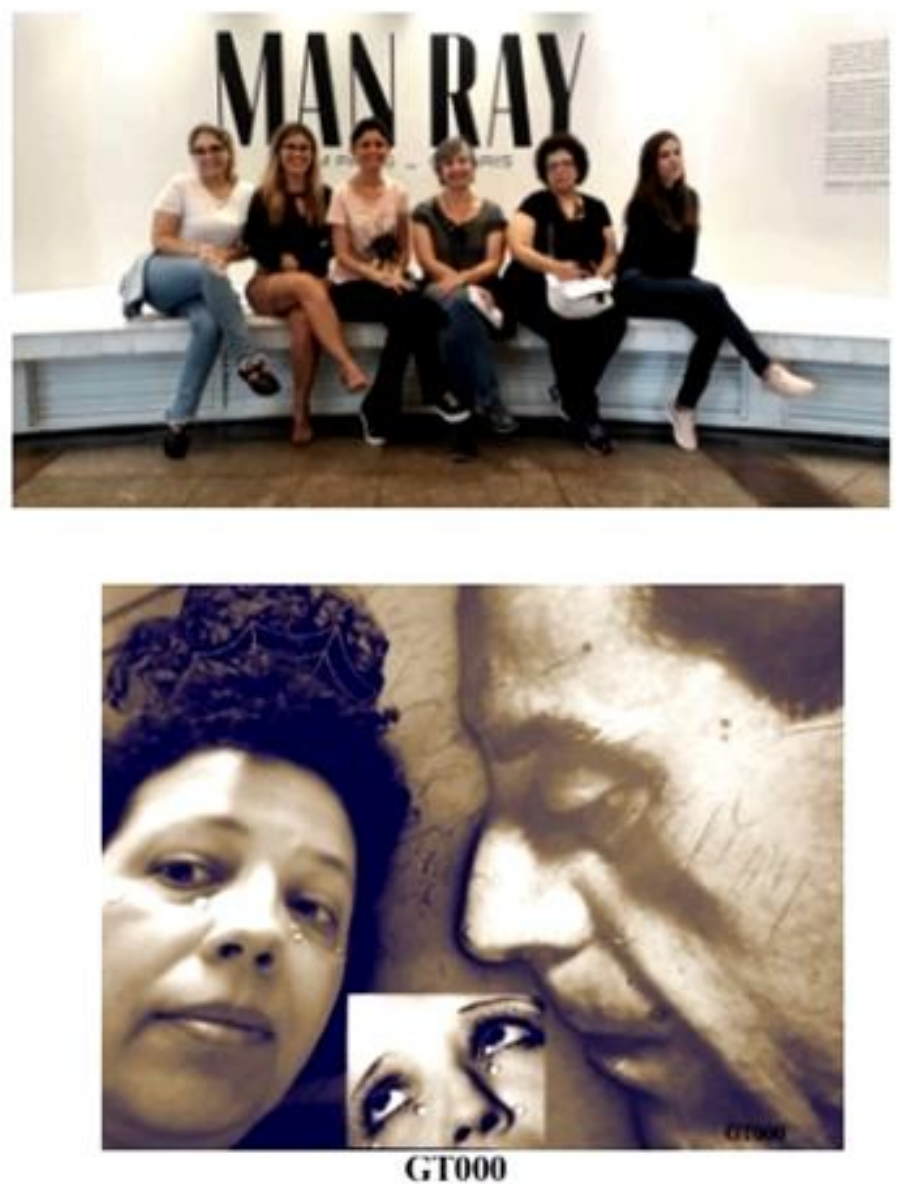

A obra de arte naio deve ser a beleza em si mesma, porque ela morreu; NEM alegre, NEM triste, NEM clara NEM obscura. Uma obra de arte nunca é bela, por decreto, objetivamente, para toda a gente. A critica é portanto inútil.

TTZ 3636 


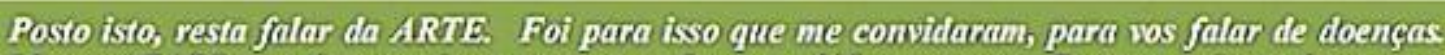
Mas o ACASO tem destas coisas: eston com fome e o bje me espera Portanto ñ̃o tenilo tempo. Tanbém näo teriho paciencia Hoje. TIT 28880
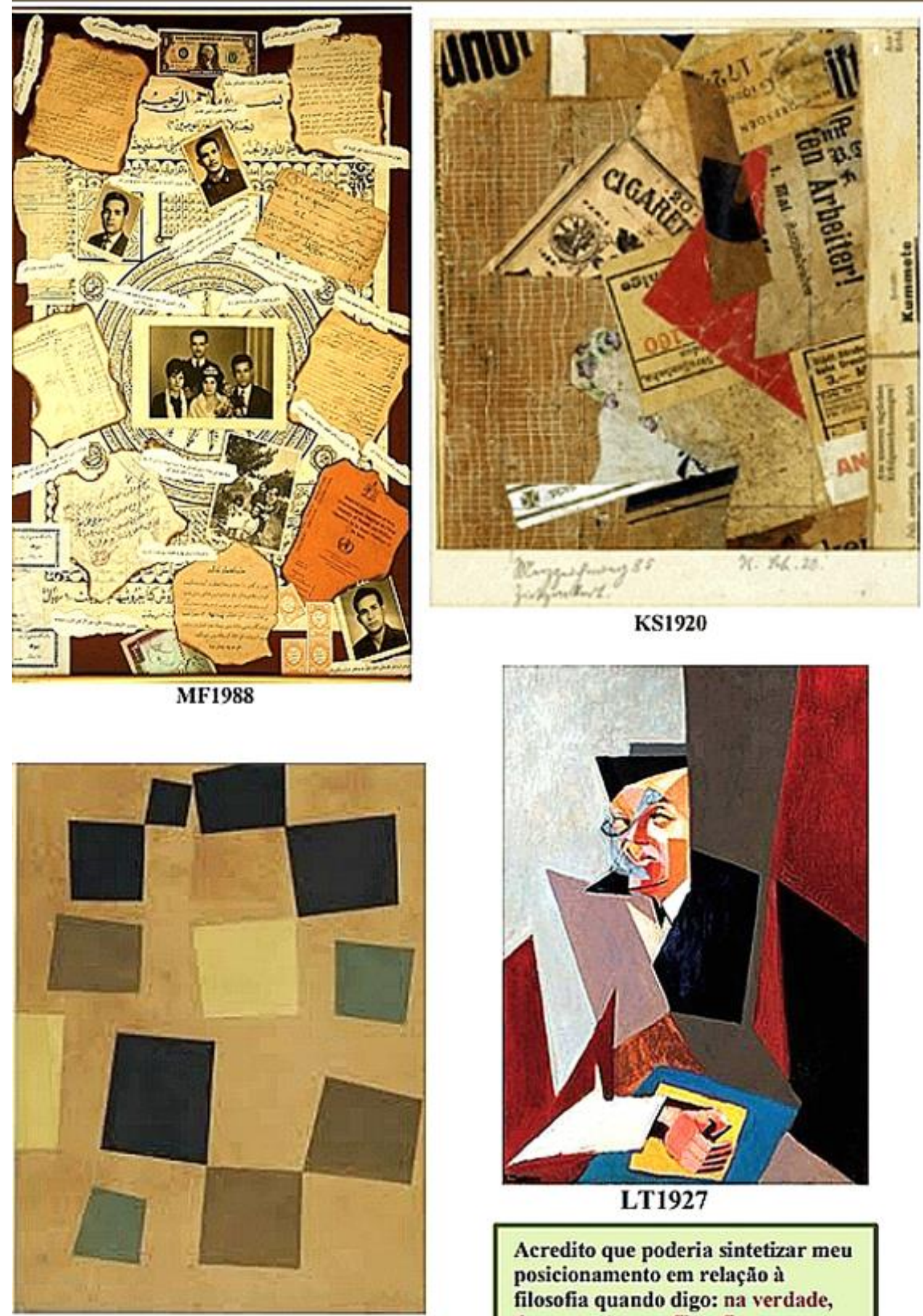

HA2001 posicionamento $\mathrm{em}$ relação ì

filosofia quando digo: na verdade, deve-se escrever filosofia apenas como se escreve um poema. LW09 


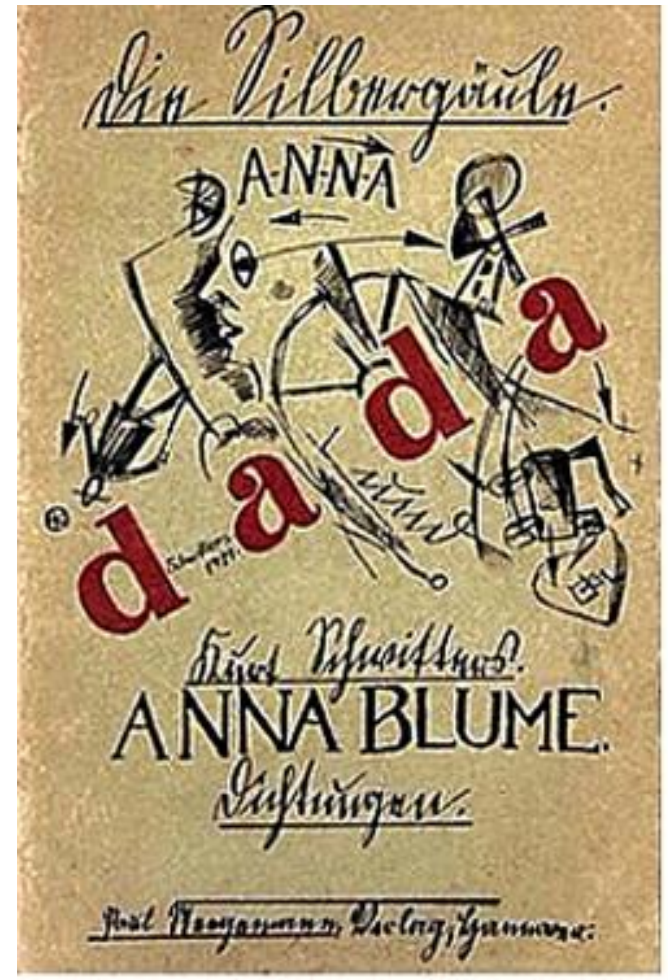

ABC1919
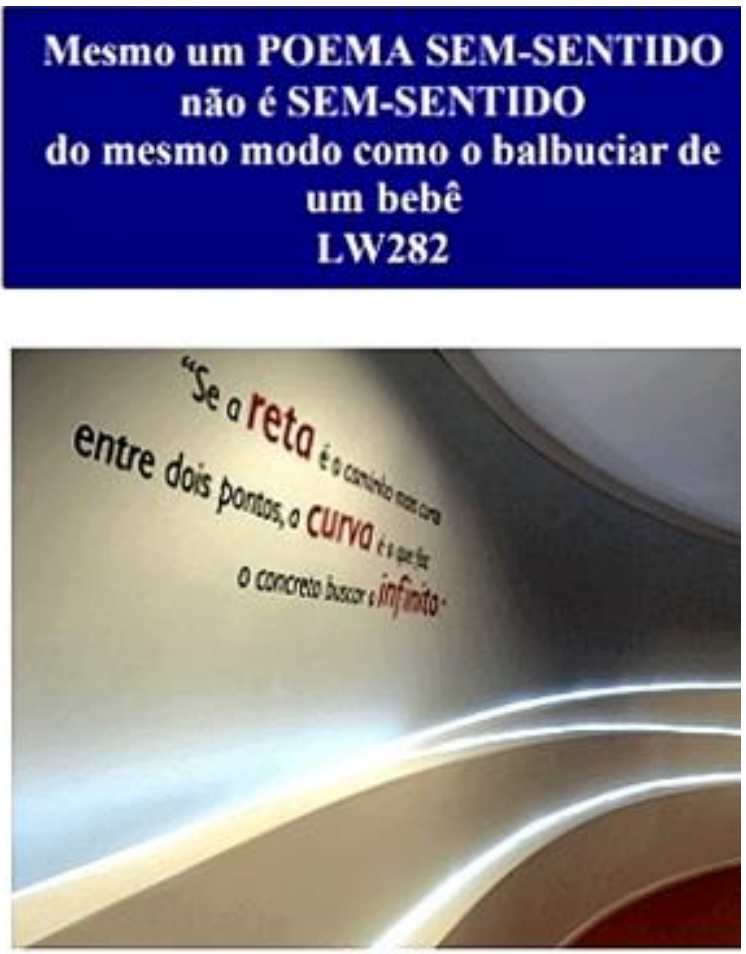

ON10

O tu, amada dos meus vinte e sete sentidos, eu the amo!

- Tu teu te a ti, eu a ti, tu a mim. -Nós?

Isto (aliás) não vem ao caso.

Quem és tu, dona inumerável? Tu és

- és? - Dizem que serias - deixa que digam,

eles nem sabem como a torre da igreja se sustém.

O chapéu sobre os pés, caminhas

sobre as mãos, com as mãos tu caminhas.

Olá, teus vestidos vermelhos, serrados em pregas brancas.

Eu amo Anna Flor vermelho, vermelho eu the amo!

- Tu teu te a ti, eu a ti, tu a mim. — Nós?

Isto (aliás) é coisa para a brasa fria.

Flor vermelha, vermelha Anna Flor, o que andam dizendo?

Responda e ganhe:

1. Anna Flor tem um macaco no sótão.

2. Anna Flor é vermelha.

3. Qual é a cor do macaco?

Azul é a cor do teu cabelo amarelo.

Vermelho é o chiado do teu macaco verde.

Tu, moça simples de vestido de chita, tu, doce

bicho verde, eu lhe amo! - Tu teu te a ti, eu

a ti, tu a mim, - Nós?

Isto (aliás) é coisa para o braseiro.

Anna Flor! Anna, a-n-n-a, gotejo o teu nome.

Teu nome pinga como tenra gordura bovina.

Sabes, Anna? Já o sabes?

Posso ler-te também de trás para frente, e tu,

a mais formosa de todas, serás sempre, de trás para frente e de frente

para trás: ma-n-n-auc.

Gordura bovina goteja acaricia minhas costas.

Anna Flor, tu, bicho gotejante, eu lhe amo!

AAB1920 

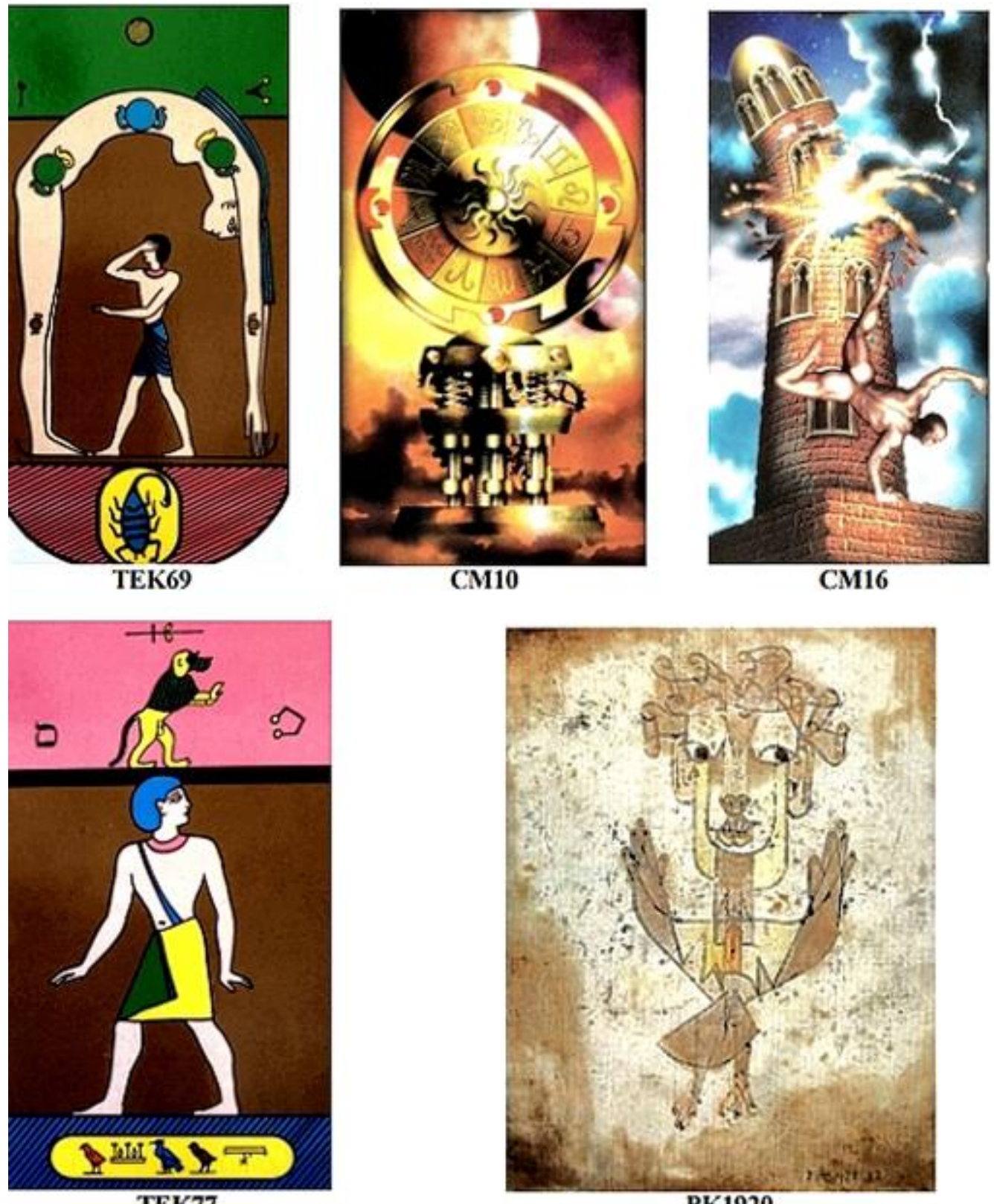

TEK77
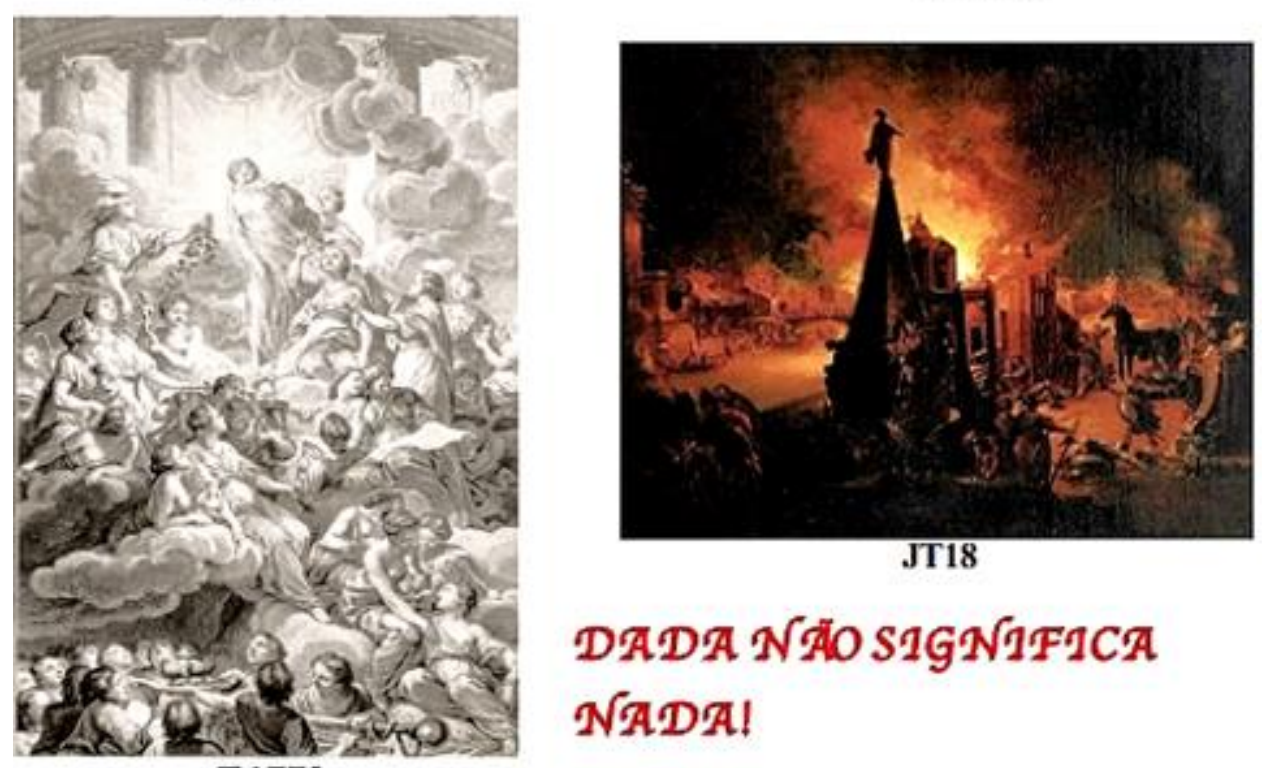

DADA ฟA゚ SIGNIFICA NADA! 


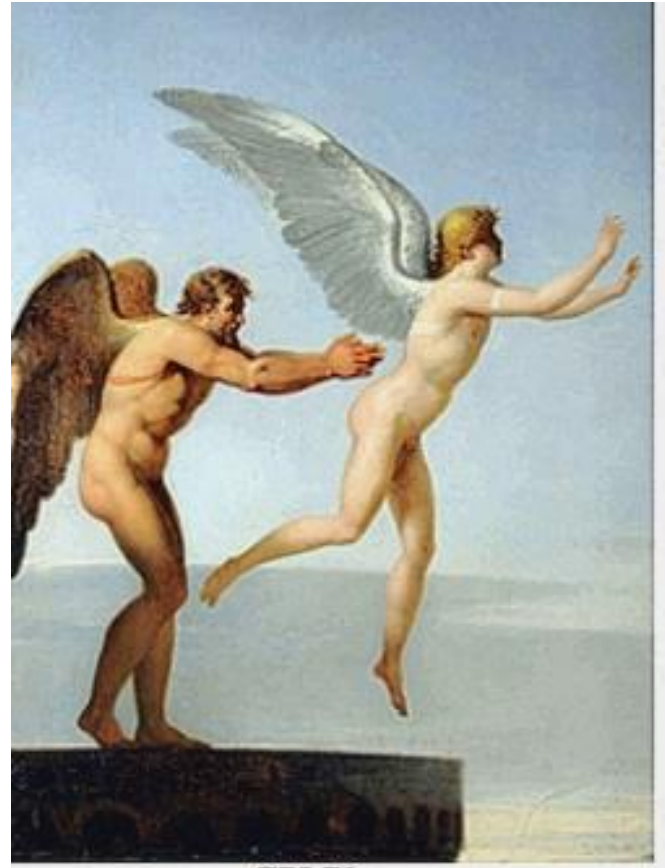

CPL71

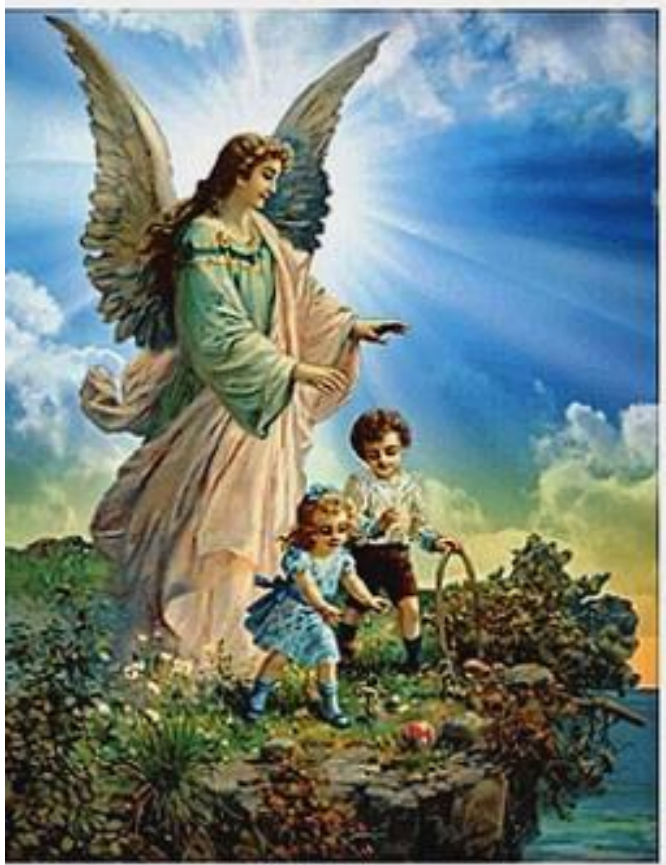

BP1825

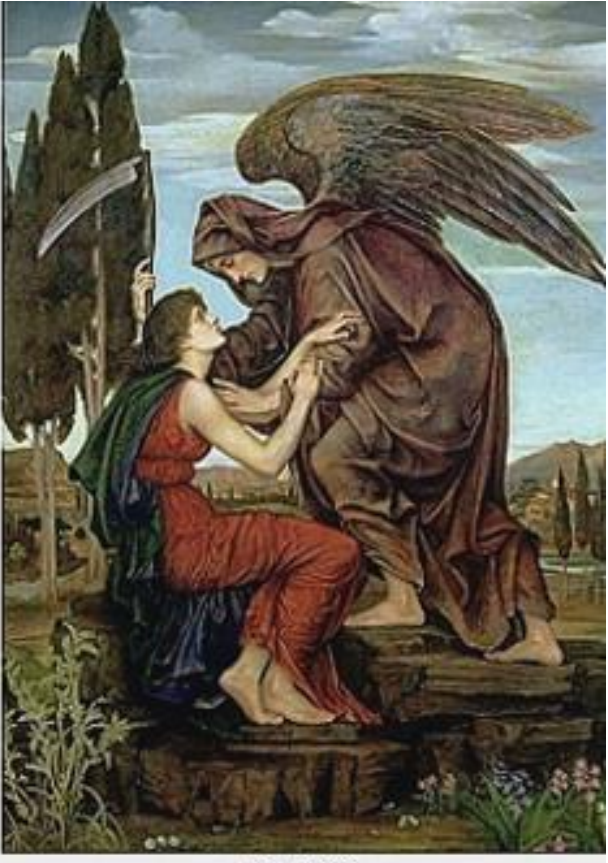

EM943

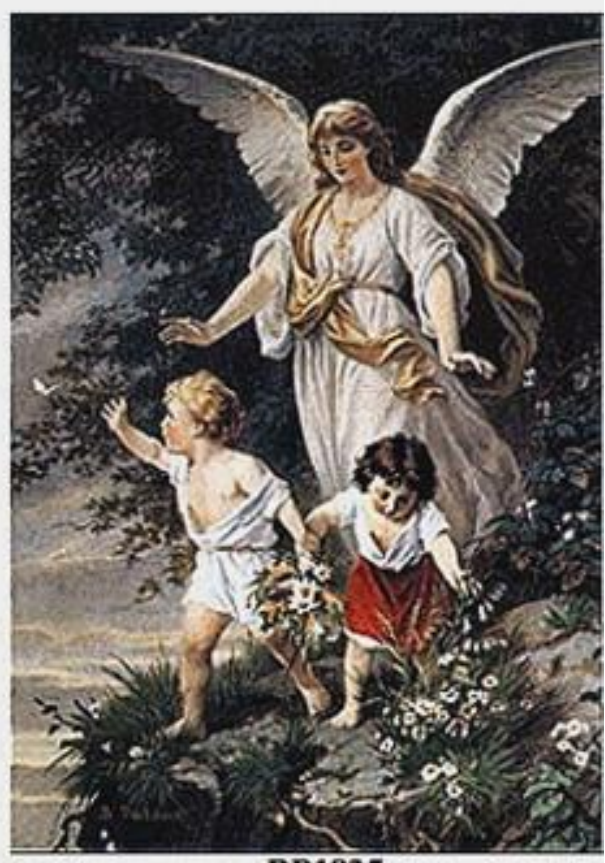

BP1825

Crianças no gabinete, há luzes encantadas, uma pistola carregada que inspira terror, uma fonte transparente, uma bacia de pedra que se espalha sobre uma cama de opalas, um caçador sem sapatos, uma menina sem cabelo, um barco no mar e um marinheiro canta, um cavalo adamascado, um teatro itinerante, um grilo, penas brancas caídas de um ninho de pombas, pequenas cestas cavadas em coração creme e rosa, uma guitarra que faz faíscas

e um vestido que será sempre novo. 


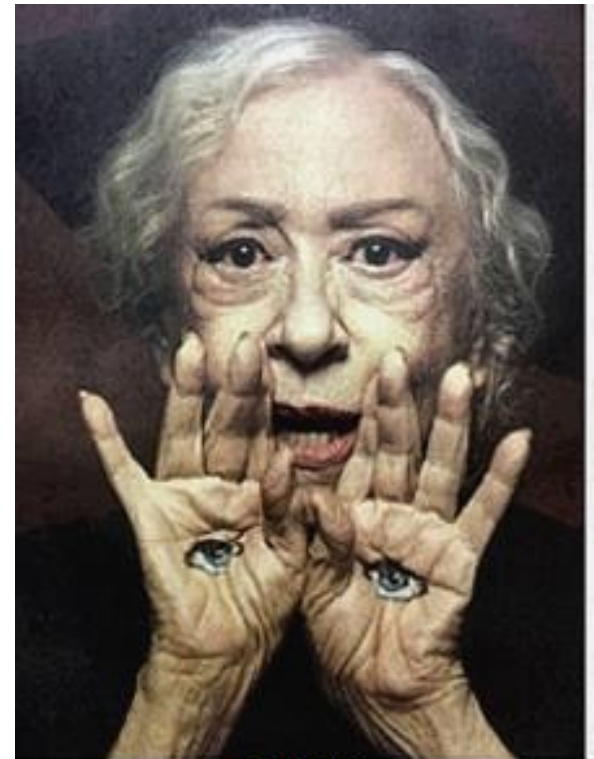

MM19

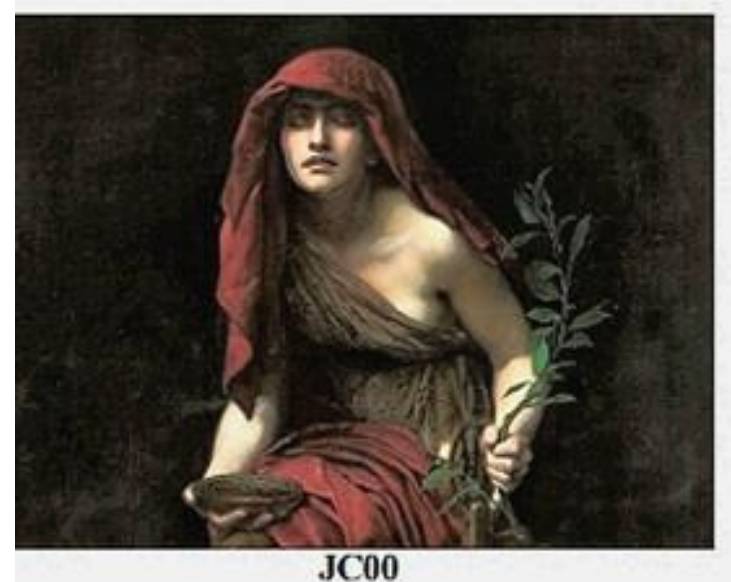

JC00

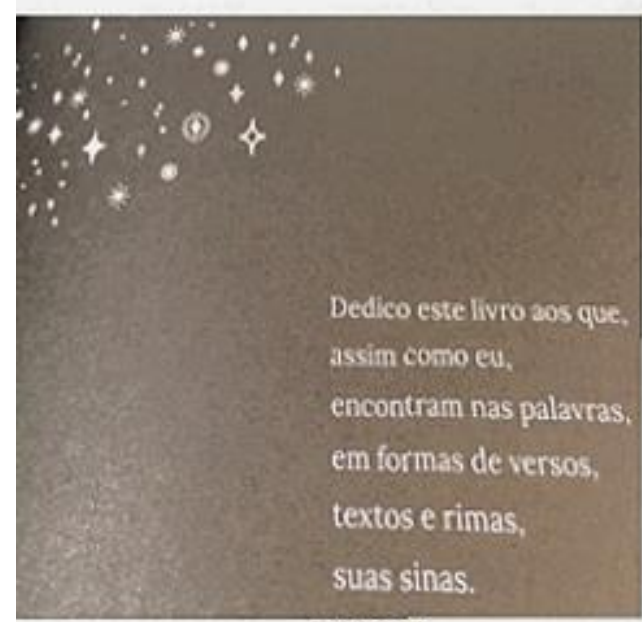

DMP18

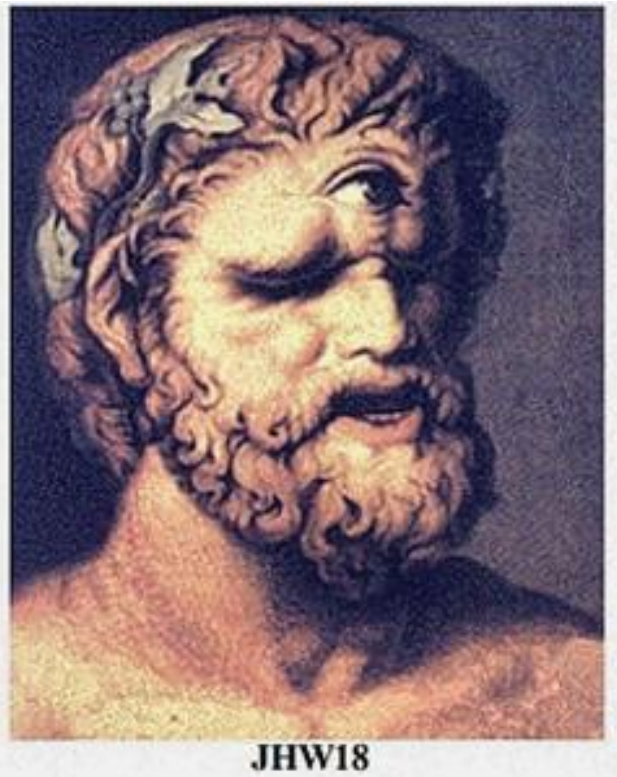

\begin{tabular}{|c|c|c|c|c|c|c|c|c|c|}
\hline$L, R$ & $L, R$ & \multicolumn{3}{|c|}{$L \in f t$. } & \multicolumn{4}{|c|}{ Right. } & \\
\hline 123,123 & $\mathrm{~T}_{4}, \mathrm{~T}_{4}$ & 4 & $3=1$ & $\mathbf{T}$ & $\mathrm{T}$ & 12 & 3 & 4 & \\
\hline 53,$355 ;$ & $35,3 s$ & $?$ & 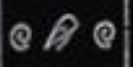 & e & @ & e e & & N & \\
\hline 53,335 & 35,35 & 7 & e 10 & (อ & (2) & e e & e) & $N$ & \\
\hline 59.558 & is, ss & D) & $@ \mathscr{A} \odot$ & a & a. & e १ & c & $\$$ & \\
\hline 953,658 & 35,35 & $?$ & (e) & @ & @ & & @ & v & \\
\hline 455,35s & 55,35 & $?$ & 200 & 7 & e & & Q) & Q & \\
\hline 155,455 & 55,35 & $?$ & 770 & 7 & e) & $9 \wedge$ & N & N & \\
\hline 55,355 & 55,55 & $?$ & 70 & e) & N. & & & $\mathbb{N}$ & 0.4 \\
\hline 15,555 & 35,55 & 7 & $\cap \wedge a$ & e & Q & A 1 & & & \\
\hline
\end{tabular}

FG4321

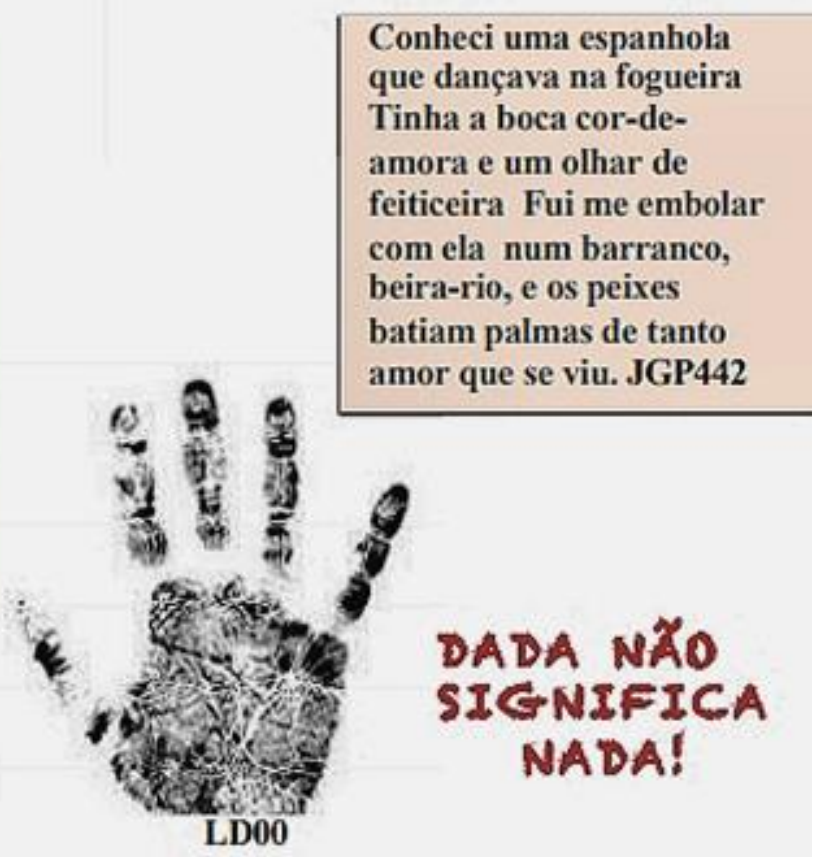




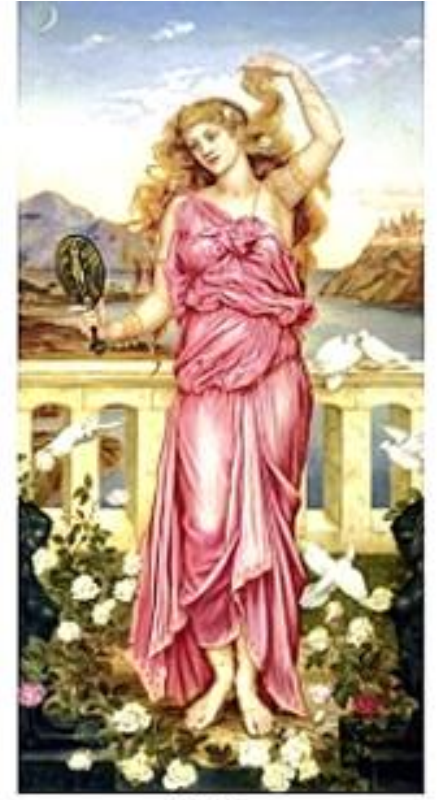

DADA

NAั0

SIGNIFICA NADA!

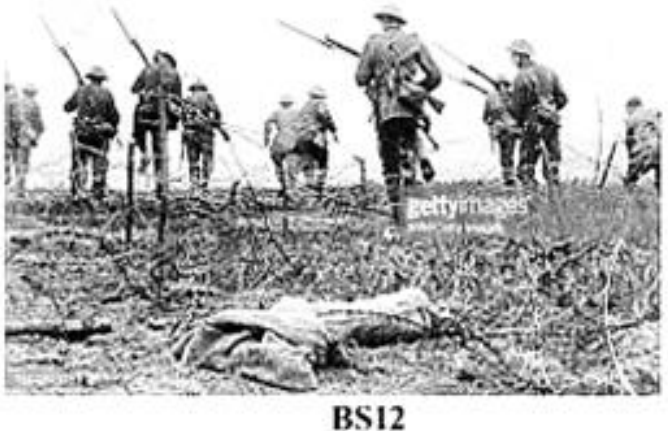

BS12

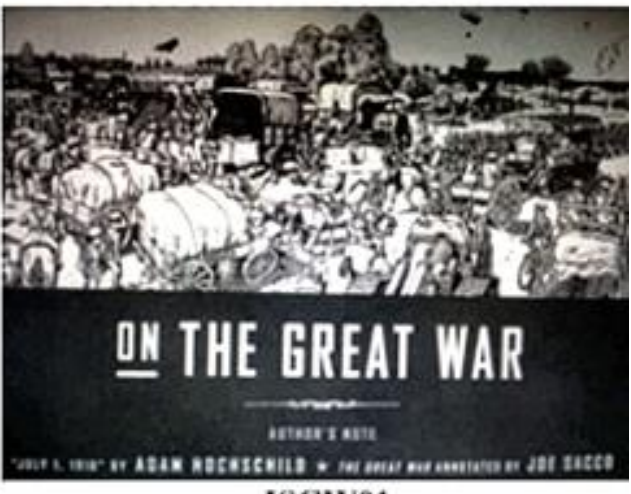

JSGW01

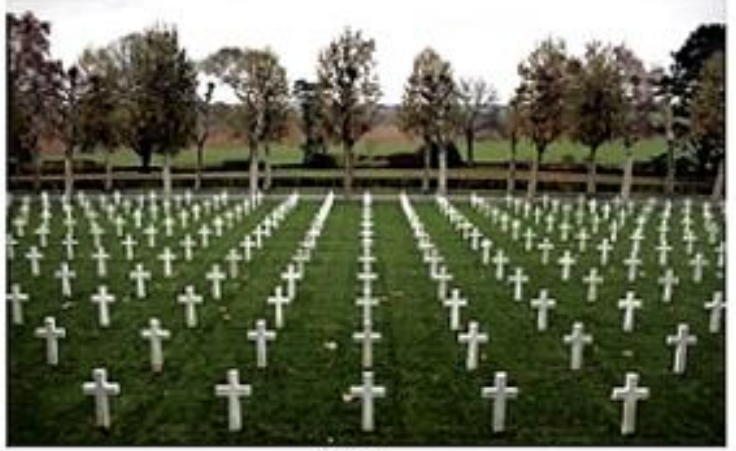

SA15

A paz fez um mar da revolução invadir meu destino.

A paz, como aquela grande explosão, uma bomba sobre o Japão fez nascer o Japũo da paz.

Eu pensei em mim.

Eu pensei em ti.

Eu chorei por nós.

Que contradição!

Só a guerra faz

nosso amor em paz.

Eu vim.

Vim parar na beira do cais, onde a estrada chegou ao fim, onde o fim da tarde é lilás, onde o mar arrebenta em mim o lamento de tantos "ais". GGJD

DADANKO SIGNIFICA NADA! 
Uma pressão barométrica mínima pairava sobre o Atlântico; dirigia-se para leste, rumo à pressão máxima instalada sobre a Rússia, e ainda não mostrava tendência de se desviar dela para o norte. As isotermas e isóteras cumpriam suas funções. A temperatura do ar estava numa relação correta com a temperatura média do ano, a do mês mais frio e a do mês mais quente e a oscilação aperiódica mensal. $O$ nascer e o pôr do Sol e da Lua, a variação do brilho da Lua, de Vênus, do anel de Saturno, e outros fenômenos importantes transcorriam segundo as previsões dos anuários de astronomia. $O$ vapor d'água no ar estava na fase de maior distensão, a umidade era baixa. Numa frase que, embora antiquada, descreve bem as condiçóes: era um belo dia de agosto de 1913.

$$
\text { RM76 }
$$

A lógica é uma complicação. A lógica é sempre falsa. Puxa pelos fios das noções, no seu exterior formal, em direção a extremidades e centros ilusórios. As cadeias da lógica matam, miriápode enorme asfixiando a independência. Casada com a lógica, a arte viveria em incesto, abocanhando, engolindo a sua própria cauda, parte do seu corpo, fornicando consigo mesma. TTZ 9090

As pessoas empregam palavras par a esconder seus pensamentos e utilizam pensamentos par a fundamentar seus erros. Se naquele tempo faziamos afirmações, elas tỉnham outro objetivo além de ser em corretas: simplesmente o de nos afirmarmos! RM77

\begin{tabular}{|c|c|}
\hline 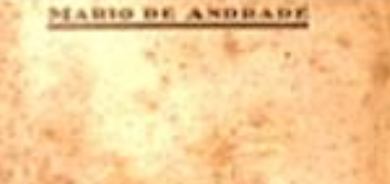 & $\begin{array}{l}\text { Observa-se. Olha-se de um ou de vários ângulos. } \\
\text { Escolhem-se os pontos de vista de entre os milhões que } \\
\text { há. A experiência também é um resultado do acaso e } \\
\text { das faculdades individuais. TTZ674 }\end{array}$ \\
\hline Maclinaina & $\begin{array}{l}\text { Foi a matemática que arruinou a alma. A matemática é } \\
\text { a fonte de uma inteligência perversa que faz o homem } \\
\text { senhor da terra, mas ESCRAVO DA MÁQUINA. } \\
\text { Ulrich ainda descobriu que também na ciência parecia } \\
\text { um homem que escalou uma montanha após outra } \\
\text { sem avistar seu objetivo. RM78 }\end{array}$ \\
\hline 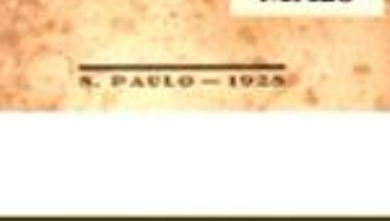 & $\begin{array}{l}\text { Mas se a vida é uma farsa de má qualidade, sem objetivo e } \\
\text { nem parto inicial, proclamamos a base única do } \\
\text { entendimento: a arte. A arte é coisa privada, o artista fala } \\
\text { para si próprio. Uma obra compreensivel é produto de } \\
\text { jornalista. TT214 }\end{array}$ \\
\hline
\end{tabular}

De toda essa embrulhada o pensamento dele sacou bem clarinha uma lua: OS HOMENS É QUE ERAM MÁQUINAS E AS MÁQUINAS É QUE ERAM HOMENS. MA5

Turing acredita que as máquinas pensam. Turing deita-se com homens. Portanto, as máquinas não podem pensar. AT42
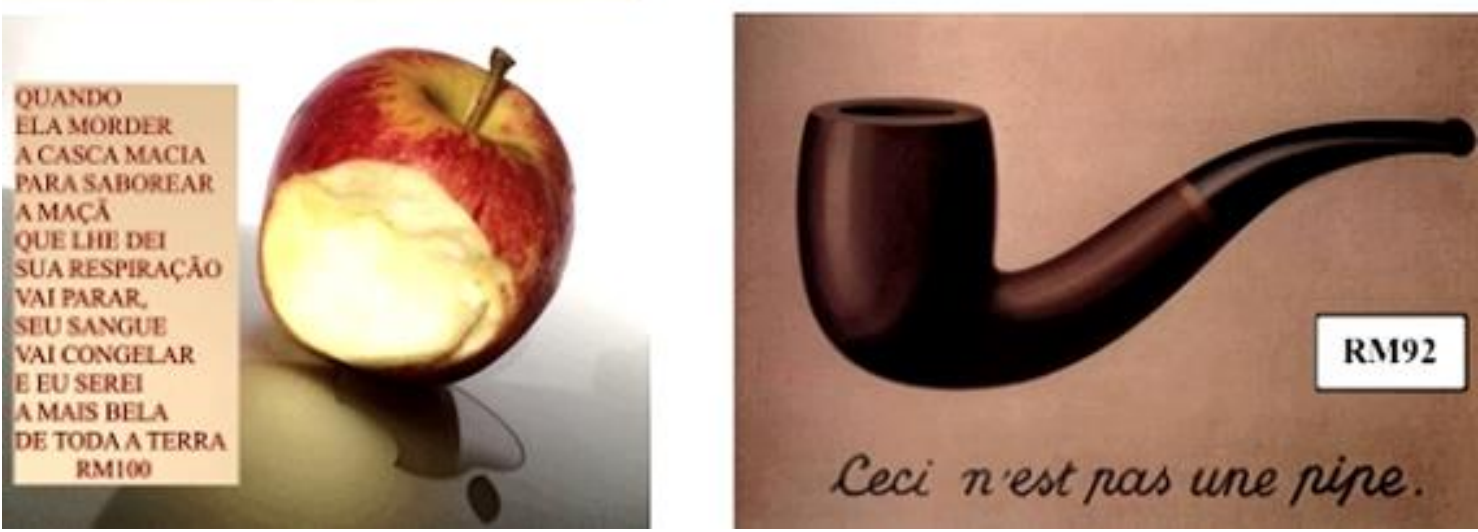


\section{Notas}

* Este texto foi originalmente publicado como artigo com base na referência seguinte e foi devidamente autorizado pelos editores da revista a ser republicado como capítulo desta obra. MIGUEL, A. (2020). Art Requiem: um anti-poema dada digital para o ocaso da arte casual. Revista Internacional de Pesquisa em Educação Matemática (RIPEM)/ International Journal for Research in Mathematics Education, v. 10 n. 2, p. 14-57, 2020. Dossier temático Literatura e Matemática: inter-relações possiveis. Organizadores: Andreia Dalcin e Rafael Montoito. Uma publicação da Sociedade Brasileira de Educação Matemática (SBEM). Links: (http://sbem.iuri0094.hospedagemdesites.ws/revista/index.php/ripem/issue/view/158) ;http://sbem.iuri0094.hospedagemdesites.ws/revista/index.php/ripem/article/view/216 7).

LB99 - Passagem do livro Les Caractères de Jean de La Bruyère (apud DIDEROT \& d'ALEMBERT, 2015, p. 310) citada por Jaucourt no verbete Vida (Fisiologia) que escreveu para a Enciclopédia de Diderot e d'Alembert (2015).

TTZ42 - Receita DADA para se fazer um poema. Esta receita se encontra no Dada Manifesto sobre o amor débil e o amor amargo (ZARA, 1987, p. 42).

TTZ78 - Capa da tradução portuguesa do livro originalmente publicado em francês sob o título Sept Manifestes Dada (TZARA, 1987).

HB44 - Segundo Taylor (2001, p. 1), 18 fotos de um manequim feminino em tamanho real, reunidas sob o título Poupée: variations sur le montage d'une mineure articulée (Boneca: variações sobre a montagem de uma menina articulada) marcaram o primeiro aparecimento público da boneca do artista plástico alemão Hans Bellmer (1902-1975), em 1934, no jornal surrealista Minotaure, e introduziram o público francês no universo de imaginação erótica desse artista.

SM100 - Versos do poema Um lance de dados jamais eliminará o acaso do poeta francês Stéphane Mallarmé (1842-1898). O poema foi originalmente publicado em francês, na revista Cosmopolis, em 1897, sob o título Un coup de dés jamais n'abolira le hasard (MALLARMÉ, 1897). A passagem do poema aqui destacada, em sua versão original em francês é a seguinte: UNE CONSTELLATION froide d'oubli et de désuétude / pas tant / qu'elle n'énumère / sur quelque surface vacante et supérieure / le beurt successif / sidéralement / d'un compte total en formation / veillant / doutant / roulant / brilliant et méditant / avant de s'arrêter / à quelque point dernier qui le sacre / Toute Pensée émet un Coup de Dés. Segundo Marie-Hélène Catherine Torres, Um Lance de dados é um longo poema de versos livres e com tipografia revolucionária. Como o diretor da revista Cosmopolis não entendia a intenção de Mallarmé, pediu ao autor que escrevesse um prefácio ao poema que se inicia com a seguinte advertência do poeta aos leitores: "Gostaria que esta nota não fosse lida ou, caso o seja, que seja logo esquecida, pois ela ensina pouca coisa ao leitor hábil'. Podemos nos perguntar como Mallarmé, poeta profundamente comprometido com a tradição versificada, teria chegado a compor 
um poema avant-garde como Um lance de dados. Graças à consciência que atingiu, no final de sua vida, acerca da crise da poesia, o que lhe permitiu elaborar uma nova forma de se fazer poesia. Assim, ele passa a dispor livremente os versos em páginas dobradas, bem como reorganiza a sintaxe por agrupamentos e períodos, transformando criticamente a alegoria e a fazer poesia como se compusesse música com palavras. [...] O poema se estende por onze páginas duplas, reproduz todas as variações tipográficas relativas ao tamanho das letras, opção por minúsculas ou maiúsculas, itálico, e espalha em torno da oração principal uma plêiade de proposições secundárias. [...] Muitos pensadores foram confrontados com o poema de Mallarmé, notadamente, Quentin Meillassoux, filósofo contemporâneo que tinha o desejo de descodificar os versos, as palavras, as sílabas e as letras. Na obra Le Nombre et la Sirène - Un déchiffrage du Coup de dés de Mallarmé, Meillassoux tenta decifrar a mensagem do poema de Mallarmé. Ele teria descoberto que o grande poema testamentário de Mallarmé, Jamais un coup de dés n'abolira le hasard, é poeticamente codificado. O código seria 707, correspondendo às 707 palavras do poema até o verbo "sagre", completado pelas sete últimas palavras da moral final do poema: todo pensamento emite um lance de dados, e 707 é o número único, o número perfeito para Mallarmé, ou seja, o número 7 , incluindo o zero, simbolizando o nada. O código só poderia ser descoberto por acaso, por alguém que contaria as palavras do poema para atingir o divino do acaso. Será por acaso a presença dos números 7 (imagem teológica) e 0 (imagem do nada)? Quem poderia conhecer a realidade poética do autor?” (TORRES, 2015, p. 304-305; p. 306-307, grifo nosso).

AE99 - Versos do astrofísico britânico Arthur Stanley Eddington (1882-1944) eleitos para epígrafe do Capítulo VII, intitulado Acaso e Probabilidade, do livro Matemática e Imaginação (KASNER; NEWMAN, 1968. p. 215).

LW4108 - Aforismo que sugere um modo fideísta de Wittgenstein (1998, p. 84) 'confiar na generosidade do acaso' para 'desconstruir pacificamente' a bistória, isto é, a oposição binária entre natureza e cultura.

TTZ2 - Foto e aforismo do poeta e ensaísta franco-romeno Samuel Rosenstock/Rosenstein (1896-1963), mais conhecido como Tristan Tzara, um dos fundadores do Movimento Dadaísta e mais conhecido por seus manifestos. Disponível em: < $\underline{\text { https://en.wikiquote.org/wiki/Tristan_Tzara> }}$. Acesso em: 16 de maio de 2020.

MF1842 - Pierre-Simon Laplace por Madame Feytaud. Óleo em tela de 1842. Disponível em: < https://pt.wikipedia.org/wiki/Pierre-Simon_Laplace> . Acesso em: 16 de maio de 2020.

FN5001 - Modo voluntarista como Nietzsche (2002, Section 203, p. 91) sugere tomar as rédeas dos acontecimentos e desconstruir agonicamente a história, isto é, a oposição binária entre natureza e cultura, normatizando, matematizando o acaso.

LA1414 - O paraíso / é exatamente como / onde você está agora / só que muito muito melhor. Primeiros versos da letra da música Linguagem é um vírus de Laurie Anderson. Laura Phillips Anderson é uma artista de vanguarda estadunidense, compositora, música e diretora de 
cinema, cujo trabalho abrange projetos de arte performática, música pop e multimídia. Disponível em: <https://en.wikipedia.org/wiki/Laurie_Anderson>. Acesso em: 16/05/2020.

EHL70 - Trecho da discussão sobre a etimologia da palavra ACASO realizada pelo grupo 'Etymology, History of languages, and Linguistics (EHL)', iniciada pelo membro de pseudônimo уәәzемеf, em 01 de janeiro de 2011. Disponível em: < http://forum.wordreference.com/threads/etymology-of-the-word-hazard.2021152/>. Acesso em: 16 de maio de 2020.

AM564 - Fotografia “Um falso lance de dado” por Antonio Miguel, 2019. Acervo Fotográfico Digital Pessoal.

JM09 - Aforismo do filósofo e historiador francês Jules Michelet (1798-1874) que expressa uma concep̧cão visionária e fatalista da história. Uma tal concepção parece ter orientado Michelet na escrita da sua obra monumental publicada em 1831 sob o título Introdução à História da Revolução Francesa (MICHELET, 1989), na qual o curso dos acontecimentos é historiograficamente explicado com base em uma suposta (teleo)lógica bélica visionária de uma batalha de longa duração que a liberdade travaria contra o acaso.

GM11 - Cena real da Primeira Guerra Mundial mobilizada no filme War Requiem (JARMAN, 1988) do artista, cineasta e roteirista britânico Derek Jarman (1942-1994). Foto de Antonio Miguel, 2019. JARMAN, Derek. War Requiem. 92 minutos. Reino Unido: Magnus Opus, 1988.

LW464 - Aforismo 464 da Parte I das "Investigações Filosóficas” de Wittgenstein (2009), em referência seu modo terapêutico de lidar com um problema filosófico e, portanto, de praticar a filosofia.

SM7050 - Versos do poema "Um lance de dados jamais abolirá o acaso" (MALLARMÉ, 1897) do poeta francês Stéphane Mallarmé (1842-1898). O poema foi originalmente publicado em francês, na revista Cosmopolis, em 1897, sob o título Un coup de dés jamais n'abolira le hasard. A passagem do poema que aqui destacamos, em sua versão original em francês, é a seguinte. LE HASARD: Choit la plume rytimique suspens du sinistre / s'ensevelir aux écumes originelles naguères / d'où sursauta son délire jusqu'à une cime / flétrie par la neutralité identique du gouffre. "Um Mestre cujo navio naufragou, antes de ser engolido pelas ondas, se prepara para lançar os dados num último desafio aos Céus desertos. Trata-se de uma alegoria transparente do colapso da era antiga e do surgimento do tempo da incerteza. [...] No título em francês Un coup de dés jamais n'abolira le hasard, que será traduzido por Haroldo de Campos por Um lance de dados jamais abolirá o acaso, está justamente presente o acaso. Mallarmé o explica ao leitor no prefácio: "Pegue um Mestre, coloque-o em um navio que está naufragando e imagine o lance de dados. Ele está nas mãos do destino. É o último desafio que lança ao céu. Mas será ele mais forte do que o acaso?” (TORRES, 2015, p. 305-306, grifo nosso). 
DJWR11 - O corpo do tenente e poeta inglês Wilfred Edward Salter Owen (1893-1918), morto em 04 de novembro de 1918, nos últimos dias da Primeira Guerra Mundial. Owen é o protagonista do filme $W$ ar Requiem (JARMAN, 1988) do artista, cineasta e roteirista britânico Derek Jarman. "Um corpo no sepulcro, uma luz de vela e uma mulher que vela: o filme de Jarman inicia-se com uma tênue luz de vela em um fundo de trevas total. Tênue luz que fornece apenas a visibilidade suficiente à vastidão noturna do vasto vazio da sala e à câmara funerária sobre a qual jaz o corpo do soldado-poeta morto" (MIGUEL, F.; MIGUEL, A., 2015, p. 198). Foto de Antonio Miguel, 2019.

HCW13 - Versos 636-639 do Canto XIII da Ilíada de Homero (c. séc. VIII a. C.). A Ilíada é o mais antigo poema épico grego e o mais antigo poema da história da literatura ocidental que chegou até nós. O título original que Homero deu ao seu poema pode ser traduzido como Ilio, que era o nome que os gregos antigos davam à cidade de Troia. O poema canta os acontecimentos de 51 dias do último ano dos dez anos ao longo dos quais se transcorreu a guerra de Troia, envolvendo gregos e troianos, provavelmente ocorrida por volta do século XII a. C. O conflito teria ocorrido como vingança dos gregos ao rapto de Helena, esposa de Menelau, o rei de Esparta e irmão de Agamemnon. Disponível no site seguinte, acessado em 28/04/2020: (https://pt.wikipedia.org/wiki/Il\%C3\%ADada).

CV1916 - Foto recente do prédio onde funcionou o cabaré artístico e político denominado Cabaret Voltaire, de fevereiro a julho de 1916. O prédio está localizado no número um da pequena Spiegelgasse, em Zurique, Suíça. O cabaré, fundado em 5 de fevereiro de 1916 por Hugo Ball (1886-1927), Emmy Hennings (1885-1948), Marcel Janco (1895-1984), Richard Huelsenbeck (1892-1974), Tristan Tzara (1896-1963), Sophie Tauber-Arp (18891943) e Jean Arp (1886-1966), é considerado o berço do movimento dadaísta, ainda que, nele, artistas de outros os movimento de vanguarda apresentassem os seus trabalhos experimentais. Foi nele que Ball leu o primeiro Manifesto Dada em 28 de julho de 1916. O nome do cabaré resultou de uma ironia intencional por parte de seus fundadores, evidenciada na manifesta discrepância entre o modo de vida diurno, supostamente austero, recolhido e discreto de um filósofo e a ruidosa vida noturna envolta aos vícios e prazeres de um cabaré. Já a atribuição do nome cabaré a um local de reuniões de artistas críticos da guerra e da burguesia justificava-se plenamente, uma vez que os eventos artísticos caóticos e anárquicos que lá ocorriam diariamente representavam, de certo modo, uma resposta agressivamente pacífica às atrocidades ruidosas efetivas de aviões, bombas e armas químicas da Primeira Guerra mundial. Nesse sentido, os eventos artísticos que lá ocorriam não eram apenas performances coreográficas, mas também formas inovadoras de performances cênicas envolvendo a literatura e recitais de poesia sonora e simultânea. Em decorrência disso, o Cabaret Voltaire foi atacado pelo público em algumas ocasiões. Disponível no site seguinte, acessado em 28/04/2020: (https://pt.wikipedia.org/wiki/Cabaret_Voltaire).

TTZ000 - "DADA não significa nada" é o que Tzara afirma logo no início do Manifesto de 1918 (TZARA, 1987, p. 12). Entretanto, no decorrer da leitura dos manifestos, é atribuído propositalmente à palavra DADA um número ilimitado de significações manifestas, o que sugere que a palavra DADA pode significar qualquer coisa, até mesmo 
o seu contrário, isto é, não-DADA. Ver, por exemplo, a seguinte passagem do Manifesto de 1918: "Fica-se a saber pelos jornais que os negros Kru chamam à cauda de uma vaca santa: DADA. O cubo e a mãe, numa certa região da Itália: DADA. Um cavalo de pau, a ama leite, a dupla afirmação em russo e em romeno: DADA. Há sapientes jornalistas que vêem nela uma arte para os bebês e há outros que jesuschamandoascriancinhas do dia vêem nela o retorno a um primitivismo seco e estrondoso, estrondoso e monótono" (TZARA, 1987, p. 12). Ver também a seguinte passagem do mesmo manifesto: "Liberdade: DADA DADA DADA, rugido das dores crispadas, abraço dos contrários e de todas as contradições, dos grotescos, das inconsequências: A VIDA. [...] Protesto de punhos cerrados de todo o ser em ação destrutiva: DADA; abolição da lógica, a dança dos impotentes da criação: DADA; abolição da memória: DADA; abolição da arqueologia: DADA; abolição dos profetas: DADA; abolição do futuro: DADA; crença absoluta e indiscutível em todo o deus que seja produto imediato da espontaneidade: DADA" (TZARA, 1987, p. 19). Ver ainda as seguintes passagens promotoras de um ceticismo radical presentes no $D A D A$ Manifesto sobre o Amor Débil e o Amor Amargo, sétimo e último manifesto que foi tornado público na Galeria Povolotzky de Paris no dia 12 de dezembro de 1920, e o seu Anexo, uma semana depois: "A priori, ou seja, de olhos fechados, DADA coloca antes da ação e acima de tudo: A Dúvida. $D A D A$ duvida de tudo. Dada é tatu. Tudo é Dada. Desconfiem de Dada" (TZARA, 1987, p. 41). "O anti-dadaismo é uma doença: a autocleptomania, o estado normal do homem é DADA. Mas os verdadeiros dadas são contra DADA. O autocleptomaníaco" (TZARA, 1987, p. 41). Mas não podemos também nos esquecer, finalmente, daquelas deliciosas passagens, carregadas de humor refinado e irônico, que são modos de significar a palavra DADA acionados no Anexo intitulado Como me tornei encantador, simpático e delicioso ao DADA Manifesto sobre o Amor Débil e o Amor Amargo: "Há pessoas (jornalistas, advogados, amadores, filósofos) que julgam que mesmo os negócios, os casamentos, as visitas, as guerras, os diversos congressos, as sociedades anônimas, a política, os acidentes, os dancings, as crises econômicas, as crises de nervos, são variações de dada. Como não sou imperialista, não partilho dessa opinião; prefiro acreditar que dada é apenas uma divindade de segunda ordem, que deve ser simplesmente colocada ao lado de outras formas do novo mecanismo das religiões de interregno. A simplicidade é simples ou dada? Acho-me bastante simpático" (TZARA, 1987, p. 50); "Durmo muito tarde. Suicido-me a 65\%. A vida fica-me muito barata, para mim não é mais que uns $30 \%$ da vida. A minha vida tem $30 \%$ da vida. Faltam-lhe os braços, umas guitas e alguns botões. 5\% são consagrados a um estado de estupor semi-lúcido acompanhado por crepitações anêmicas. Estes $5 \%$ chamam-se DADA. Portanto a vida é barata. A morte é um bocadinho mais cara. Mas a vida é encantadora e a morte também é encantadora (TZARA, 1987, p. 49).

PL12 - Página de rosto do livro "Ensaio filosófico sobre as probabilidades" do matemático, astrônomo e físico francês Pierre-Simon Laplace (1749-1827), publicado pela $\mathrm{M}^{\mathrm{ME}} \mathrm{V}^{\mathrm{X}}$ Courcier Imprimeur-Libraire pour les Mathématiques, Paris, quai des Augustins, n. 57, 1814.

PL76 - Primeiro parágrafo do livro "Ensaio filosófico sobre as probabilidades" (LAPLACE, 1814, p. 1) do matemático, astrônomo e físico francês Pierre-Simon Laplace (1749-1827). 
EM1893 - Uma das quatro pinturas expressionistas (1893) de uma série denominada " $O$ grito" do pintor norueguês Edvard Munch (1863-1944), Disponível em:

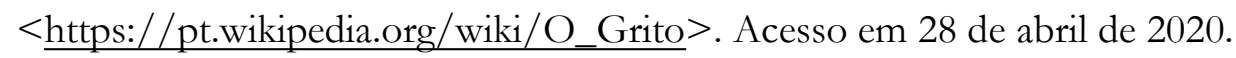

WO4433 - Tradução livre por (MIGUEL, F.; MIGUEL, A., 2015, p. 196) do seguinte poema intitulado Anthem for Dead Youth (Hino para a juventude morta) do poeta e tenente inglês Wilfred Edward Salter Owen (1893-1918), morto em 04 de novembro de 1918, na Batalha de Sambre da Primeira Guerra Mundial: "What passing bells for these who die as cattle? / Only the monstrous anger of the guns. / Only the stuttering rifles' rapid rattle / Can patter out their hasty orisons / No mockeries for them from prayers or bells, / Nor any voice of mourning save the choirs, / The shrill, demented choirs of wailing shells; / And bugles calling for them from sad shires. / What candles may be held to speed them at all? / Not in the hands of boys, but in their eyes / Shall shine the holy glimmers of good-byes./ The pallor of girls' brows shall be their pall; / Their flowers the tenderness of silent minds, / And each slow dusk a drawing-down of blinds". Alguns dos poemas de Owen, tal como o aqui se apresenta, inspiraram a produção da obra sinfônica pacifista intitulada War Requiem, Opus 66, do compositor inglês Benjamin Britten (1913-1976), concluída em 1962. Segundo Miguel F. \& Miguel A., "na liturgia cristã da igreja católica, o réquiem é uma espécie de prece ou missa especialmente composta para um funeral. $\mathrm{O}$ termo réquiem foi retirado da expressão latina requiem aeternam dona eis, que significa dai-lhes o repouso eterno. [...] Na música, por sua vez, o termo faz referência às composições feitas para coro de vozes e vozes isoladas que entoam os textos litúrgicos relatados na primeira acepção. Assim, o réquiem aparece como um gênero híbrido, tanto musical quanto literário. Uma primeira transgressão dessa tradição cometida por Britten foi a de romper com o caráter litúrgico dos réquiens ao produzir o seu $W$ ar Requiem não com o propósito de rogar a Deus pela libertação eterna de um defunto específico, no dia do julgamento final, mas sim com o propósito de, nesse dia, levar a julgamento e à condenação eterna às labaredas do inferno a própria guerra enquanto uma prática cultural, vista por Britten, em seu pacifismo radical, como monstruosa e degradadora da espécie humana. Como extensão dessa primeira transgressão, há uma segunda, que acaba por reforçar ainda mais o caráter profano ou secular do War Requiem de Britten, dado que ele mantém uma semelhança de família meramente formal com a estrutura composicional de um texto de réquiem. Tal transgressão se caracteriza pelo fato do Requiem de Britten enxertar intencionalmente no texto latino tradicional do réquiem poemas pacifistas de Owen, tal como o intitulado Hino para a Jwventude Morta" (MIGUEL F. \& MIGUEL, A., 2015, p. 195). A tradução do poema em foco tomou como base a sua versão inglesa, tal como aparece no encarte textual que acompanha o CD-Áudio do War Requiem de Britten (BRITTEN, 1996), escrito por Keith Anderson (ANDERSON, 1996).

DJWR54 - O desesperado grito mudo da enfermeira (a atriz Tilda Swinton) do filme $W$ ar Requiem (JARMAN, 1988) do artista, cineasta e roteirista britânico Derek Jarman (19421994) em sua vigília do corpo do tenente e poeta inglês Wilfred Owen (1893-1918), protagonista do filme de Jarman, tragicamente assassinado nos últimos dias da Primeira Guerra Mundial. Foto de Antonio Miguel, 2019. 
TTZ 2233 - Excerto do "Manifesto DADA de 1918” (TZARA, 1987, p. 11). Segundo Souza \& Silva (2007, p. 5), “à primeira vista, [a contradição intencional deste excerto] reside no fato de Tzara não creditar valor ao manifesto, mas de apresentar-se, porém, com todas as suas conotações e anseios, através de um manifesto. Mas, em uma leitura mais aprofundada deste excerto, se poderia dizer que o seu objetivo é mostrar o caráter desagregador do manifesto, [...] e nos faz repensar a seguinte passagem do Manifesto de 1918: o futurismo lançou-se contra o passado e sonbou uma superliteratura no século da "velocidade"; o expressionismo via a destruição do mundo, mas sabendo que do caos se organizaria uma estrutura superior, que era a verdadeira beleza. Para os dadaístas, entretanto, não havia passado, nem futuro: o que havia era a guerra, o nada; e a única coisa que restava era produzir uma antiarte [...]".

GW68 - Grafite nos muros de Paris em 1968 (FEENBERG; KELLNER, 2001, p. 7).

MG1916 - "O Carrossel (1916) é a obra prima do pintor britânico Mark Gertler (18911939). Considerada por muitos críticos a expressão artística inglesa mais importante da Primeira Guerra Mundial, esta pintura mostra homens e mulheres, militares e civis numa representação rígida, de modo a parecerem coloridos bonecos mecânicos. Às voltas no carrossel, eles transportam consigo uma condição sinistra: as figuras boquiabertas parecem aprisionadas no brinquedo, num choro silencioso. Esta obra é considerada uma sátira aos horrores da Guerra - nesta época, as pessoas começavam a tomar consciência das atrocidades do período. Esta obra integra a coleção da Tate Gallery, em Londres. Os soldados alemães que lutaram na Primeira Guerra Mundial recebiam cartões postais em branco para serem enviados a suas famílias ansiosas por notícias. Alguns escreviam cartas detalhadas, mas o jovem Otto Schubert criou neles pequenas obras de arte; ele tinha 23 anos na época de sua convocação. Durante o tempo em que ficou na batalha, fez dezenas de cartões postais para sua noiva e para sua irmã, com desenhos que contavam os detalhes do dia a dia nas trincheiras. Cem anos depois, cerca de 70 desses cartões estão sendo expostos na galeria Pepco Edison Place, na capital americana, Washington". Passagem do texto "Arte na Primeira Guerra Mundial" de Gabriella do Nascimento (NASCIMENTO, 2017).

PL60 - Esta afirmação de Laplace, expressa no seu Ensaio filosófico sobre as probabilidades (LAPLACE, 1814), manifesta o seu ponto de vista determinista radical acerca da possibilidade de normatização/matematização do acaso por parte dos seres humanos. Tal afirmação foi apresentada como uma hipótese ficcional determinista acerca do modus operandi da natureza, assemelhando-a e assimilando-a a uma máquina.

CFP33 - Definição de instituições de previdência social, companbias de seguro etc. presentes no livro Aritmética Comercial (PAULA, 1943, p. 191) do engenheiro civil e professor brasileiro Carlos Francisco de Paula (1884-1963). Paula foi um respeitado autor de livros destinados ao ensino escolar de matemática, no período de 1910 a 1944, que atuou como professor no renomado Colégio Culto à Ciência, na cidade de Campinas, Estado de São Paulo. Disponível em: $<$ http://cultoaciencia.net/autor.htm>. Acesso em 15 de maio de 2020. 
OI31 - Imagem do orixá Orunmilá-Ifá esculpida em madeira por Carybé, nome artístico de Hector Julio Páride Bernabó (1911-1997), que foi um pintor, gravador, desenhista, ilustrador, ceramista, escultor, muralista, pesquisador, historiador e jornalista argentino, naturalizado brasileiro. A escultura encontra-se em exposição no Museu Afro-Brasileiro, na cidade de Salvador, Estado da Bahia, Brasil. Na mitologia e religião africanas Iorubá, Orunmilá é um orixá, isto é, um deus que pratica a adivinhação e realiza profecias. Por sua vez, Ifá é uma palavra africana que nomeia o oráculo utilizado por Orunmilá, o qual só transmite as suas instruções através de um sacerdote denominado babalaô. Este, dispõe de três métodos diferentes de consultar o oráculo, os quais lhe permitem interpretar os desejos e determinações dos orixás. Disponível em: $<$ https://pt.wikipedia.org/wiki/Ifá $>$; $<\underline{\text { https://pt.wikipedia.org/wiki/Carybé> }} ; \quad<\underline{\text { https://pt.wikipedia.org/wiki/Orunmila }>}$. Acesso em 15 de maio de 2020.

PT097 - Previsão do tempo em Campinas às 20h38min de uma sexta-feira qualquer: um passado que já foi futuro e que clama por se tornar presente neste texto sem contexto definido.

BZ256 - Tipos variados de "búzios", "dados" ou "contas" do jogo de búzios - cocos do dendezeiro, conchas marinhas ou réplicas desses objetos - utilizados na prática da buziomancia, um tipo de prática divinatória entretecida em religiões tradicionais de matriz africana, praticada com frequência em países latino-americanos, dentre eles, o Brasil. Quatro lançamentos consecutivos dos búzios por parte do adivinho formam um dos dezesseis padrões básicos do jogo. Na língua iorubá, cada um desses padrões é denominado um odu. A prática da buziomancia é consagrada a Orunmila-Ifá, um orixá da profecia, e a Exu que, como o mensageiro dos orixás, confere autoridade ao oráculo, uma vez que, os praticantes do jogo acreditam que esses orixás influenciam os 256 arranjos posicionais possíveis dos búzios que se espalham sobre a mesa. Como todos os búzios participam dos quatro lançamentos consecutivos, deduzimos, pela fórmula de arranjo com repetição da Análise Combinatória - $\operatorname{Ar}(\mathrm{m}, \mathrm{p})=\mathrm{mp}$-, que os 16 padrões básicos do jogo, quando arranjados 2 a 2 , produzem $\operatorname{Ar}(16,2)=162=256$ arranjos possíveis dos 16 odus. Sob um olhar Wittgensteiniano, a prática africana da buziomancia, a prática árabe da geomancia e a prática chinesa do I Ching mantêm entre si semelhanças de família. Disponível em : <https:/ /pt.wikipedia.org/wiki/Jogo_de_búzios >. Acesso em 15 de maio de 2020.

GC660 - Chuvas que virão. Foto Antonio Miguel, em um dia sem chuva de setembro de 2019.

PL55 - Passagem do livro “Ensaio filosófico sobre as probabilidades” (LAPLACE, 1814, p. 4) em que Laplace apresenta a sua definição de probabilidade, isto é, o seu modo de normatizar o acaso.

MD1918 - Epígrafe do Segundo Manifesto Dada, intitulado "Manifesto Dada 1918" (TZARA, 1987, p. 11), cuja leitura pública ocorreu em 23 de março de 1918 na cidade de Zurique. 
OA77 - Combinação aleatória de passagens do "Manifesto Antropófago" (ANDRADE, 1928) do escritor, ensaísta e dramaturgo brasileiro Oswald de Andrade (1890-1954).

HP40 - Passagem do texto intitulado “O acaso”(POINCARÉ, 1968, p. 69), do matemático francês Henri Poincaré (1854-1912). O que Poincaré está dizendo com isso é análogo a se dizer que após o lance de um dado cúbico, uma única vez, é absolutamente imprevisivel que, após a sua queda, a face voltada para cima mostre o número 1 ou 2 ou 3 ou 4 ou 5 ou 6 . Porém, ele parece estar supondo que a experiencia prova (o que equivaleria, talvez, a dizer que o acaso prova?) que repetindo-se $n$ vežes o lançamento desse dado - $n$ tendendo ao infinito -, a ocorrência do fato 'a face do dado que se volta para cima é 1 ou 2 ou 3 ou 4 ou 5 ou 6' tende a estabilizar-se em torno de 1/6 (um sexto), independentemente de realizarmos ou não essa experiência. Em outras palavras, Poincaré está significando a palavra probabilidade como a frequência-limite da repetição ad infinitum de um evento, como usualmente se faz no campo de ciências ditas experimentais como a Estatística, a Física, a Economia etc. Em um texto intitulado Significado de probabilidade (NAGEL, 1968), o filósofo das ciências e da matemática Ernest Nagel (1901-1985) se propõe analisar criticamente cinco usos contextuais diferentes - por ele vistos como limitados ou mesmo inadequados - da palavra probabilidade quando tais usos são contrastados com o uso que dela se faz no contexto da matemática pura: 1) na conversação cotidiana; 2) no campo da estatística aplicada e das medidas; 3) no contexto das teorias físicas e biológicas; 4) na comparação de teorias por seus respectivos graus de probabilidade; 5) no ramo das matemáticas conhecido como cálculo de probabilidades. $\mathrm{Na}$ perspectiva de Nagel, tanto a significação de probabilidade como a frequência-limite da repetição ad infinitum de um evento defendida por Poincaré, quanto a significação de probabilidade baseada na oposição binária entre acaso e certez̧a, que o próprio Poincaré critica, se mostram insuficientes ou inadequadas. De acordo com Nagel (1968, p. 91), a última destas duas significações, que ele considera ter sido exposta com com vigor pelo lógico e matemático indiano Augustus De Morgan (1806-1871), “[...] a palavra provável se refere ao estado de ânimo referente a uma afirmação da qual não existe completa certeza ou conhecimento. Disso resulta que o grau de certeza de uma proposição, sua "probabilidade", é o grau de crença que com ela se mantém. Pois a certeza tem graus, e todos os graus de conbecimento, segundo se pretende, são suscetíveis de serem concebidos quantitativamente. Portanto, é possível aplicar o cálculo de probabilidades aos graus de crença, se definimos a probabilidade algebricamente como a razão do número total de alternativas favoráveis de um acontecimento ao número total de alternativas equiprováveis. A transição desta definição para a anterior se baseia no princípio da razão suficiente ou da indiferença, de acordo com o qual duas proposições são igualmente prováveis se a força de nossa crença se divide igualmente entre ambas" (NAGEL, 1968, p. 91). Porém, quando aplicado ao exemplo particular do lançamento do dado cúbico que estamos considerando nesta nota, a força deste contra-argumento genérico de Nagel à significação de probabilidade baseada na oposição binária entre acaso e certeza deveria ser vista como tão igualmente forte quanto a força de nossa crença de que ao lançarmos este dado para cima uma única vez, após a sua queda, é igualmente crivel que a face voltada para cima mostre o número 1 ou 2 ou 3 ou 4 ou 5 ou 6. $\mathrm{Ou}$ ainda - caso esses dados cúbicos possuíssem cores diversas, por exemplo: verde, vermelho, amarelo, azul, preto e branco -, acreditar tão fortemente que, após o lançamento 
do dado vermelho, a face voltada para cima seria 2, quanto acreditar que, após retirar um desses dados de dentro de uma urna na qual todos foram previamente colocados, o dado retirado seria azul. Em resumo, o contra-argumento de Nagel - que se assenta numa oposição binária ou distinção radical entre conbecimento e crença-, ainda que suponha enfraquecer a significação determinista de probabilidade baseada na oposição binária entre acaso e certeza a é tão igualmente fraco quanto a própria crença determinista nessa oposição. Ele nada mais faz do que substituir a crença na oposição binária entre acaso versus certez̧a pela crença na oposição binária crença versus conbecimento. Por sua vez, Nagel (1968, p. 95, grifo do autor) pondera do seguinte modo a significação da palavra probabilidade como a frequência-limite da repetição ad infinitum de um evento: "Esta definição de probabilidade acrescenta um aspecto que outras omitem, qual seja, o da frequência relativa. Consequentemente, a probabilidade passa a ser vista como uma relação entre proposições, mas uma relação analisável; em segundo lugar, toda explicação que predique probabilidades é uma proposição material para a qual se necessita a evidência empírica; em terceiro lugar, a probabilidade denota uma relação entre as classes de proposições, de modo que uma explicação sobre a probabilidade de uma única proposição é um modo elíptico de afirmar uma relação entre classes de proposições com uma daquelas às quais pertence a proposição dada. [...] Isto posto, não podemos definir a probabilidade como limite de uma razão no sentido matemático. Posto que se a probabilidade de uma proposição fosse tal limite, teria que haver um termo na série estudada, para o qual a diferença entre o limite e a frequência relativa determinada empiricamente seria menor que qualquer magnitude pré-fixada. Mas, se houvesse um tal termo para uma magnitude previamente dada, necessariamente se derivaria que as frequências empíricas não poderiam desviar-se do limite mais do que a sua magnitude. Não obstante, isso contradiz os teoremas estabelecidos no cálculo de probabilidade”. Ocorre, porém, que a validação das proposições tidas como teoremas estabelecidos no cálculo de probabilidade no contexto da matemática dita pura, se assenta exclusivamente nas definições, axiomas e regras de inferência do sistema dedutivo no qual tais proposições adquirem o estatuto de teoremas, isto é, de proposições verdadeiras. Além disso, as regras de inferência de todos esses sistemas dedutivos não são senão regras de uma lógica ou de um jogo de linguagem que funcionam como um sistema de auto-validação do próprio jogo e, portanto, de auto-validação ou de correção daquilo que poderia ser considerado uma proposição verdadeira (um teorema) ou uma proposição falsa. Portanto, o contra-argumento de Nagel aqui utilizado para criticar a significação de probabilidade como a frequência-limite da repetição ad infinitum de um evento se assenta na crença de que as regras que orientam os jogos de linguagem que usam ou significam a palavra probabilidade no contexto da matemática dita pura poderiam funcionar como regras de correção de todos os jogos de linguagem que usam ou significam diferentemente a palavra probabilidade em outros contextos de atividade humana que se orientam por outras regras para lidarem com problemas que se constituem em função de propósitos sociais distintos que se apresentam nesses diferentes contextos.

CFP89 - Definição de tabela de mortalidade presente no livro “Aritmética Comercial' (PAULA, 1943, p. 190) do engenheiro civil e professor brasileiro Carlos Francisco de Paula (18841963). Paula foi um respeitado autor de livros destinados ao ensino escolar de matemática, no período de 1910 a 1944, que atuou como professor no renomado Colégio Culto à Ciência, na cidade de Campinas, Estado de São Paulo. Disponível em: 


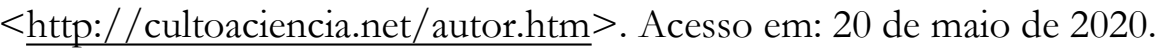

JLRD77 - Passagem do verbete leis da natureza escrito por d'Alembert para a "Enciclopédia" (DIDEROT; d'ALEMBERT, 2015, II, 41, p. 124-125).

JG1662 - Passagem do livro de John Graunt Natural and Political Observations made upon the Bills of Mortality (GRAUNT, 1665).

AM2019 - Um caso de falso acaso. Fotografia de Antonio Miguel, outubro de 2019.

JG1663 - Capa do livro escrito pelo comerciante londrino John Graunt (NEWMAN, 1968, p. 27), intitulado Natural and Political Observations Mentioned in a following Index, and made upon the Bills of Mortality (Observações naturais e politicas mencionadas em um indice a seguir, e feitas sobre Tábuas de Mortalidade). Newman (1968, p. 104) considera Graunt o fundador da estatística, uma vez que "[...] este livreto escrito por ele teria sido o primeiro esforço de interpretação dos fenômenos biológicos de massa e da conduta social, a partir de dados numéricos, no caso, o esforço de se pôr a limpo os números brutos de nascimentos e mortes em Londres, no período de 1604 a 1661”. Segundo Newman, este livreto de 1662, juntamente com um outro escrito pelo eminente astrônomo Edmund Halley (1656-1742), constituem “[...] a base de todo o trabalho posterior sobre esperança de vida, indispensável para a solvência das companias de seguros de vida" (NEWMAN, 1968, p. 104).

HP20 - Passagem do texto intitulado O acaso (POINCARÉ, 1968, p. 68), do matemático francês Henri Poincaré (1854-1912). Nesse texto, Poincaré questiona a perspectiva determinista radical sob a qual filósofos e matemáticos, a partir de Pierre Simon Laplace, passaram a significar o acaso como incerteza ou não-certeza, opondo-o, portanto, binariamente, à certeza, para defender uma perspectiva determinista restrita que desdobra o acaso em acaso fortuito e acaso não-fortuito: "Podemos falar em leis do acaso? Não é o acaso a antítese de toda lei? Deste modo se expressa Bertrand na primeira parte do seu Calcul des probabilités. Nele, a probabilidade se opõe à certeza; e, pois, àquilo que se ignora e, por conseguinte, àquilo que não poderia ser calculado. $\mathrm{O}$ acaso não seria senão a medida de nossa ignorância e os fenômenos fortuitos não seriam senão aqueles cujas leis, por definição, ignoramos. E assim, nós nos tornamos deterministas absolutos, e aqueles que querem preservar os direitos humanos de livre arbítrio deixam o determinismo sem divisão dentro do mundo inorgânico. [Para o determinismo absoluto], todo fenômeno, por menor que seja, tem uma causa, e um espírito infinitamente poderoso e bem informado acerca das leis da natureza poderia prevê-la desde o princípio dos séculos. Mas, se um espírito semelhante existisse, não poderíamos jogar com ele qualquer jogo de azar, pois perderíamos sempre, de modo que a palavra acaso não teria sentido, ou então, não haveria acaso. Existe, pois, uma contradição nesse modo de se conceber o acaso. Quando os primeiros pastores caldeus seguiam com os olhos os movimentos dos astros e não conheciam ainda as leis da Astronomia, teriam eles podido insinuar que os astros se moviam ao acaso? Se um físico moderno estuda um fenômeno novo e descobre, numa terça-feira, a lei que o rege, teria ele dito, na segunda-feira, que este fenômeno era fortuito? [...] É preciso, pois, que o acaso seja outra coisa que o nome que damos à nossa ignorância. 
É preciso que, entre os fenômenos cujas causas ignoramos, distingamos os fenômenos fortuitos, sobre os quais o cálculo de probabilidades nos informará provisoriamente, e os que não são fortuitos, sobre os quais não podemos dizer nada até que tenhamos determinado as leis que os regem. $\mathrm{E}$ mesmo para os fenômenos fortuitos é evidente que o que nos ensina o cálculo de probabilidades não perderá validade no dia em que estes fenômenos forem melhor conhecidos" (POINCARÉ, 1968, p. 68-69, grifo nosso).

AN99 - Navegando na Internet em busca de informações sobre o surgimento das identificações digitais na história, fui conduzido pelo acaso a esta imagem de uma impressão digital anônima.

FD19 - Atitude de resignação indiferente diante do infortúnio que lhe impôs o acaso manifestada pelo compulsivamente persistente jogador Aleksei Ivánovitch - narrador do romance Um Jogador (DOSTOIEVSKY, 2004) do escritor russo Fiodor Dostoievsky (1821-1881) -, que, após perder quase toda a fortuna que havia ganho na roleta de um cassino parisiense, ficando com uma insignificante quantia que lhe permitiria ou comer ou jogar, não hesita e decide: - Vou apostar!

SM42 - O poeta francês Stéphane Mallarmé (1842-1898) retratado pelo fotógrafo francês Félix Nadar (1820-1910). A foto é de 1896. (https://pt.wikipedia.org/wiki/Stéphane_Mallarmé). Segundo Torres, "Mallarmé desempenhou um papel fundamental na evolução da literatura no século XX e esteve especialmente voltado para as tendências futuristas e dadaístas, colocando-se entre um dos precursores da poesia concreta. Sua poesia e prosa caracterizam-se pela musicalidade e experimentação gramatical" (TORRES, 2015, p. 303). Poesia concreta, no sentido literal da palavra, mas também poesia como ação, movimento, performance da palavra: "Mallarmé reflete sobre o volume e sua estrutura; vê o livro como uma forma tridimensional, com profundidade, espessura e solidez; sente a necessidade de compor o espaço. Constrói jogos de relações entre opostos: o branco e o negro, o jornal e o livro, a eternidade e o instantâneo, a vida e a morte, o aberto e o fechado, o fixo e o móvel, a irrealidade e a realidade, sempre relacionando-os com uma estrutura - a deste objeto absoluto que pudesse fazer com que o mundo terminasse em um Livro. Assim, fica claro, o processo de Mallarmé se funda fortemente sobre uma análise visual. [...] A introdução da ação era importante, não por meio de artifícios externos, mas, sim, com seus próprios elementos a página, a frase, o verso, a palavra, a letra -, uma vez que Mallarmé via o livro como expansão total da letra e considerava que, dela, dever-se-ia explorar o movimento. Tal objeto não seguiria uma paginação mas, sim, leis de permutação; as páginas poderiam mudar de lugar segundo ordens distintas - seriam folhas móveis que de alguma maneira possibilitariam um sentido (PANEK, 2006, p. 104-105, grifo nosso).

JK19 - Talvez (pois nunca podemos dizer com certeza) possamos acrescentar ao ponto de vista que este aforismo expressa concisamente, que a evidência das proposições que mobilizam palavras que participam do campo semântico da palavra probabilidade não deveria ser buscada nem no discurso metafísico e nem mesmo no discurso da Física, mas tão somente no discurso da Lógica. Isso porque, foi este o ponto de vista que o economista 
britânico John Maynard Keynes (1843-1946) defendeu no seu livro intitulado "Treatise on Probability", escrito no período de 1906 a 1912, sob a influência dos "Principia Etbica" (1903) de George Eward Moore (1873-1958) e dos "Principia Mathematica” (1910, 1912 e 1913) de Bertrand Russell e Alfred North Whitehead. Na introdução (NEWMAN, 1968, p. 41- 46) que o matemático e historiador da matemática norte-americano James R. Newman (19071966) faz ao texto intitulado "A aplicaşão da probabilidade ao comportamento" (NEWMAN, 1968, p. 47-60) que ele selecionou do "Treatise on Probability" de Keynes, ele diz que a dura crítica que faz Keynes, nesta obra, à teoria clássica da probabilidade teria sido também influenciado pelo ceticismo do filósofo britânico David Hume (1711-1776) em relação ao princípio de causalidade. O ceticismo de Hume em relação a este princípio se expressa em sua crença de que se dois acontecimentos A e B ocorrem simultaneamente, é impossível provar a existência de uma conexão causal entre eles. Nessa perspectiva, em sua crítica à concepção determinista de probabilidade, Keynes partiu da hipótese da variável independente limitada, segundo a qual as propriedades das coisas reveladas em nossa experiência com elas decorreriam de um número finito de propriedades geradoras, havendo, portanto, uma probabilidade finita, embora pequena, em favor de uma conexão causal entre duas quaisquer dessas propriedades. Segundo Keynes, a evidência dessa hipótese se basearia na experiência. E, talvez, devêssemos acrescentar, baseia-se na experiência e familiaridade de Keynes com todos os tipos de jogos de risco, uma vez que ele foi um inveterado jogador que, durante toda a sua vida, jogou com êxito na Bolsa de Valores, bem como jogou outros jogos mais amigáveis. Talvez. (pois nunca podemos dizer com certeza) tenha sido devido a esta crença na evidência da experiência postulada por Keynes que Newman (NEWMAN, 1968, p. 47) acrescenta as três seguintes epígrafes ao texto seleto de Keynes: 1) A probabilidade é a verdadeira guia da vida (Obispo Butler); 2) É uma verdade certa que, quando não está em nossas mãos determinar o que é a verdade, devemos seguir o que é mais provável (René Descartes); 3) A vida é a escola da probabilidade (Walter Bagehot). A composição desta nota baseia-se em (NEWMAN, 1968, p. 41- 46).

LW7 - Composição de três aforismos (WITTGENSTEIN, 1998, p. 70); (WITTGENSTEIN, 2010, TLP 6.371- 6.372) do filósofo austríaco Ludwig Wittgenstein (1889-1951).

GG666 - Versos escolhidos da canção intitulada "Ele Falava Nisso Todo Dia” (GIL, 1968) do cantor e compositor brasileiro Gilberto Gil.

TTZ20 - Nesta passagem do Manifesto de 2018, Tzara (1987, p. 12) chama de burguês dramaturgo todos aqueles que se deixam orientar pelos princípios da lógica e da racionalidade, tentando reduzir a pluralidade de significados de uma palavra - no caso, a palavra DADA - a uma definição única e inequívoca. E, por extensão, ele ironiza o burguês dramaturgo que tenta racionalizar as narrativas, recorrendo a qualquer método psicanalítico que procura dar um sentido aos eventos, conectando-os mediante o princípio determinista da causalidade, segundo o qual todo acontecimento é necessariamente produzido por uma causa e toda causa produz necessariamente um efeito.

BS12 - Cena da Batalha de Somme ocorrida entre 01 de julho e 18 de novembro de 1916, nas margens do rio Somme, no nordeste da França, travada entre a França e o Império 
Britânico contra o Império Alemão, na Primeira Guerra Mundial. Disponível em: <http://omhso.blogspot.com/2014/08/a-batalha-do-somme.html\#>. Acesso em 20/05/2020.

SA90 - O primeiro Manifesto Dada - denominado "Manifesto do Senhor Antipyrina" - se conclui desta forma: com uma pseudo-adição, uma pseudo-divisão e uma pseudo-aplicação da prova dos nove. A sua leitura pública se deu em 14 de julho de 1916, na cidade de Zurique. Uma tentativa de significar, não porém de explicar - pois isto, certamente, nos levaria a assumir involuntariamente o rótulo de burguês dramaturgo, que nos seria atribuído por Tzara (ver a nota T'TZ20) - este aparente contrassenso proposital na maneira de realizar operações aritméticas elementares e de verificar a sua correção nos remete a estabelecer uma conexão entre o modo como Tzara termina o Manifesto de 2016 e o modo como inicia o Manifesto de 2018. A primeira frase do primeiro parágrafo do Manifesto de 2018 é a seguinte: "Para lançar um manifesto é preciso querer: A. B. \& C. disparar contra 1, 2 \& 3, __. Como se nota, a primeira frase não é concluída na segunda linha, uma vez que, após o número 3 , Tzara coloca uma vírgula e deixa propositalmente em branco o resto do espaço da segunda linha, e continua a primeira frase não exatamente no início da terceira linha, mas após ter deixado um pequeno espaço em branco. E a continua do seguinte modo: “[...] enervar-se e aguçar as asas para conquistar e espalhar pequenos e grandes a, b, c, assinar, gritar, jurar, arranjar a prosa segundo uma forma de evidência absoluta, irrefutável, [...]. Souza \& Silva (2009, p. 5) significam o espaçamento proposital como um procedimento ao qual teria recorrido Tzara, que consiste em representar os objetivos do manifesto por letras maiúsculas (A. B. C.) e a situação atual pela sequência infinita dos números naturais $(1,2$, 3, ...): "O fato de querer "A.B.C.," para "conquistar e espalhar pequenos e grandes a, b, c" nos dá viés para a interpretação de que os resultados pretendidos são diferentes daqueles alcançados, como se fosse necessária uma representação maior para acessar objetivos relativamente menores. Toda esta sugestão e violência requerem um preço que logo é representado pelos números, dos quais podemos tecer referências equiparando-os às estéticas e aos conceitos vigentes, naquele dado momento. O que não podemos deixar de evidenciar é que após a disposição daquilo que deverá ser exterminado, há, graficamente, um espaço - "fulminar 1,2,3,___ ” -, o que nos induz a interpretar que, talvez, poderão ser fulminados muito mais do que um, dois ou três, pois os numerais não possuem uma demarcação final após sua apresentação. Sutilezas gráficas que permearam grande parte da literatura vanguardista europeia e modernista brasileira". Porém, no caso aqui em pauta o do contrassenso proposital no modo de se realizar e verificar a correção de operações aritméticas - tais "sutilezas gráficas" nos parecem menos sutis do que poderíamos supor à primeira vista, uma vez que propõem, manifestamente, fulminar, desconcertar ou enlouquecer a própria lógica, racionalidade ou normatividade inequívoca dos jogos matemáticos de linguagem. Assim, ao fazer a antilógica casual dos manifestos contracenar com o contrassenso intencional no modo de se realizar as operações aritméticas, Tzara deseja afetar performaticamente o leitor alertando-o para a tragédia da mercantilização e do engessamento normativo-formal da arte e, em particular da poesia. De fato, é para a denúncia dessa mercantilização da arte que parece apontar o seguinte excerto do Manifesto de 1918: "Assim nasceu DADA: duma necessidade de independência, de desconfiança em relação à comunidade. Quem é dos nossos conserva a sua liberdade. Não reconhecemos 
teoria nenhuma. Estamos fartos das academias cubistas e futuristas: laboratórios de ideias formais. Ou será que se faz arte para ganhar dinheiro e para fazer festas aos simpáticos burgueses?" (TZARA, 1987, p. 13). Nessa mesma direção vai este outro aforismo irônico do Manifesto de 1918: "DADA é o letreiro da abstração. O anúncio e os negócios também são elementos poéticos" (TZARA, 1987, p. 15). Por sua vez, nos seguintes excertos do Manifesto de 1918, o ataque à lógica, ao pensamento racional e à explicação racional são manifestamente literais e vistos como características do discurso psicanalítico e da forma de vida burguesa: “Acredita-se ser possível explicar racionalmente, pelo pensamento, o que se escreve. Mas é muito relativo. [...] A dialética é uma máquina divertida que nos conduz - de modo banal - às opiniões que teríamos de qualquer forma”. (TZARA, 1987, p. 16). "Haverá alguém que acredite ter demonstrado a verdade e estabelecido a exatidão de suas opiniões pelo refinamento da lógica? (TZARA, 1987, p. 16). "A psicanálise é uma doença perigosa. Adormece os pendores anti-reais do homem e sistematiza a burguesia. Não existe Verdade última" (TZARA, 1987, p. 16).

CSP67 - Com esta afirmação, o filósofo, lógico, matemático e linguista norte-americano Charles Sanders Peirce (1839-1914) inicia o seu texto intitulado As vermelhas e as pretas (PEIRCE, in NEWMAN, 1968, p. 20-26). E a continua assim: "Há duas certezas concebíveis em relação a qualquer hipótese: a certeza de sua verdade e a certeza de sua falsidade". [...] A probabilidade é uma variável contínua, e daí decorre as grandes vantagens que traz para a teoria das probabilidades o estudo da lógica. [...] O grande problema da lógica, qual seja, o problema de como a observação de um fato pode dar-nos o conhecimento de outro fato independente, se reduz a uma mera questão de aritmética. Talvez tenha sido por essa razão, qual seja, a de defender um modo de significar o estudo das probabilidades reduzindo-o ao estudo da Lógica, que Peirce, em uma nota de rodapé do texto aqui referido, atribui, nos seguintes termos, a autoria original dessa concepção ao matemático inglês John Venn (1834-1923): “O conceito de probabilidade aqui exposto é, em essência, o que Venn formulou pela primeira vez em seu Logic of Chance. Até então, havia uma vaga concepção da ideia, mas o problema era esclarecê-la completamente, e a ele pertence o mérito de ter sido o primeiro a fazê-lo" (PEIRCE, in NEWMAN, 1968, p. 20 e p. 22).

OA822 - Combinação aleatória de passagens do "Manifesto Antropófago" (ANDRADE, 1928) do escritor, ensaísta e dramaturgo brasileiro Oswald de Andrade (1890-1954). De acordo com Leonardo Davino de Oliveira, "ao amalgamar auricular - que se refere a ouvido - e oracular - que se refere a oráculo - para produzir o neologismo orecular, Oswald investe no sentido da audição, da escuta como meio de acesso às sabedorias oferecidas pela gaia ciência" (OLIVEIRA, 2014).

AW4 - A exatidão é uma fraude: frase proferida pelo filósofo, lógico e matemático inglês britânico Alfred North Whitehead (1861-1947) na última conferência que proferiu em 1941. Segundo Alexander Roob, com tal aforismo, Whitehead expressa de forma concisa a sua oposição radical à concepção mecanicista da naturę̧a desenvolvida pela física moderna, a qual teve expressão máxima nos Princípios Matemáticos da Filosofia Natural de Isaac Newton (1643-1727), e que ramificou a natureza em dois mundos: o dos fatos objetivos e o da 
percepção subjetiva dos fatos objetivos. Alternativamente, após a sua ruptura com o logicismo, Whitehead, criticando também a teoria da relatividade de Albert Einstein, desenvolveu uma filosofia organicista de inspiração platônica que propõe superar essa dicotomia entre fatos objetivos e percepção subjetiva dos fatos com base numa concepção mercurial da natureza que teria sido atestada pela mecânica quântica do século XX, através da detecção de um princípio oscilante por detrás da cortina rígida das leis fundamentais de Newton. Segundo tal princípio as formas exteriores das partículas subatômicas dependem do próprio ato de observação. Segundo Roob (2006, p. 28), tal concep̧̧ão organicista mercurial da natureza desenvolvida por Whitehead, e que ficou conhecida como filosofia do processo, devido ao caráter dinâmico e mutacional que ela atribui aos fenômenos naturais que escapariam, assim, a quaisquer tentativas de controle e determinação, apresentaria semelhanças de família com o discurso alquímico, para o qual o princípio mercurial feminino simbolizava o proteísmo ou plasticidade dos fenômenos da natureza, a sua inconstância fluida e transformacional. Diferentemente de toda a tradição filosófica ocidental, a filosofia do processo de Whitehead defende uma concepção não-determinista da natureza, dado que concebe os processos interdependentes que envolvem todos os seres naturais, dentre eles também os seres humanos, como uma rede inconsútil e não causal de fenômenos consequentes, isto é, que afetam, que se afetam e produzem efeitos sobre o mundo em que vivemos.

TTZ943 - (TZARA, 1987, p. 51). É claro que este desconcertante silogismo conduz a uma falácia lógica, isto é, a um sofisma ou conclusão logicamente falsa. É claro também que Tzara aciona intencionalmente este silogismo ilusionista com o propósito de ironizar as práticas de formalização, normatização e mercantilização da arte; em outras palavras, aciona-o para denunciar o processo então em curso de colonização da arte pelo rigor formal da lógica e da matemática. Por sua vez, essa estratégia discursiva (ana)lógica - pelo fato de manter uma analogia com um silogismo lógico - que Tzara elege para manifestar esta denúncia é a ridicularização do próprio discurso normativo da lógica e da matemática, tornando-os auto-contraditórios. De fato, é fácil perceber a analogia entre esse silogismo acionado

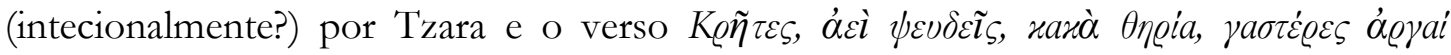
(Cretenses, sempre mentirosos, bestas más, ventres ociosos), dito em um tom não intencionalmente paradoxal pelo filósofo-poeta cretense Epimênides (século VI a.C), num poema em que o rei Minos de Creta se dirige a Zeus, extraído da obra Kontıxá (Crética) (HARRIS, 1907, p. 336). Tal verso, destacado do seu contexto, foi posteriormente mobilizado inúmeras vezes, sempre para se evidenciar o seu tom logicamente paradoxal. Seguem-se algumas dessas formulações: "Todos os cretenses são mentirosos, como um poeta cretense me contou"; "Estou mentindo"; "Todas as afirmações escritas nesta página são falsas", afirmação esta escrita numa página de papel em branco. O paradoxo envolvido em afirmações desse tipo se torna aparente quando explicitamos as duas premissas do silogismo que o produz. Premissa maior: "Epimênides afirmou que todos os cretenses são mentirosos". Premissa menor: "Epimênides é cretense". A conclusão paradoxal consiste no fato de que se admitirmos serem ambas as premissas verdadeiras, aceitando, portanto, que Epimênides diz a verdade, a conclusão que se segue é que Epimênides é mentiroso. Por outro lado, se admitirmos serem ambas as premissas falsas, aceitando, portanto, que Epimênides diz uma mentira, a conclusão que se segue é que Epimênides diz uma verdade. Note-se que, nesse silogismo, a regra de inferência acionada para se chegar a essa conclusão paradoxal é a 
seguinte: "se minto, então, não minto; portanto, minto; portanto, não minto...", e assim indefinidamente. Essa é a razão pela qual o denominado Paradoxo de Epimênides é mais conhecido como o Paradoxo do mentiroso. Tal paradoxo expõe uma contradição insolúvel instalada no coração do próprio discurso da Lógica e que voltou à cena, na virada do século 19 para o 20, por ter mostrado o seu poder desestabilizador na discussão relativa à fundamentação da matemática, na qual se envolveram matemáticos, filósofos e matemáticos filósofos, tais como: Friedrich L. Gotlob Frege (1848-1925), David Hilbert (1862-1943), Bertrand A. W. Russell (1872-1970), Kurt Gödel (1906-1978), Ludwig Wittgenstein (1889-1951), entre outros.

MA77 - Passagem do "Manifesto Antropófago" (ANDRADE, 1928) do escritor, ensaísta e dramaturgo brasileiro Oswald de Andrade (1890-1954). O Manifesto foi lido para amigos, em 1928, na casa do poeta, escritor, musicólogo e crítico literário brasileiro Mário de Andrade (1893-1945). Prosa poética carregada de humor político irônico e desconstrucionista, o propósito do Manifesto, segundo o próprio autor, era o de reivindicar o uso de uma língua literária não catequisada. Convertendo a alternativa binária Hamletiana do to be or not be that is the question na alternativa binária indígena do tupi or not tupi that is the question, o Manifesto, enfatizando o mote de que "só a antropofagia nos une", propunha "deglutir" o legado cultural do colonizador europeu e "digeri-lo" sob a forma de uma arte tipicamente brasileira.

JG45876 - Tabela de Enterros e Batizados (1662) na cidade de Romsay, na Inglaterra, feita por Jonh Graunt (HALD, 2003, p. 94).

JD2001 - Aforismo do filósofo e pedagogo norte-americano John Dewey (1859-1952) citado por Newman (1968, p. 123) como epígrafe ao texto As primeiras tábuas de seguros de vida, escrito em 1693 pelo astrônomo e matemático britânico Edmund Halley (1656-1742).

FMA94 - Esta é uma das epígrafes que Newman (1968, p. 27) acresce ao texto intitulado "A probabilidade da indução" do filósofo, lógico, matemático e linguista norte-americano Charles Sanders Peirce (1839-1914). O autor do aforismo é o filósofo iluminista francês François-Marie Arouet (1694-1778), mais conhecido pelo pseudônimo Voltaire.

MR65 - Aforismo e obra do artista e fotógrafo modernista vanguardista norteamericando Emmanuel Radnitzky - (1890-1976), mais conhecido como Man Ray que contribuiu de maneira expressiva com os movimentos dadaísta e surrealista. Disponível em: < https://en.wikiquote.org/wiki/Man_Ray $>$. Acesso 15 mar 2020.

MR2019 - Integrantes do Grupo de Pesquisa HIFEM - da esquerda para a direita: Renata Caterine Gambaro Cleto da Silva, Adriana de Bortoli, Elmha Coelho M. Moura, Arlete Brito, Virgínia Cardia Cardoso e Raquel Gomes Fernandes - em visita à Mostra Man Ray em Paris ocorrida no Centro Cultural Banco do Brasil (CCBB), na cidade de São Paulo, Brasil, no período de 21 de Agosto a 28 de Outubro. Fotografia tirada em 05 de outubro de 2019 por ocasião da realização do $4^{\circ}$ Encontro Nacional do Grupo de Pesquisa em História, Filosofia e Educação Matemática (HIFEM), ocorrido na Universidade Federal do ABC, na cidade de Santo André, Estado de São Paulo, Brasil. Disponível em: 


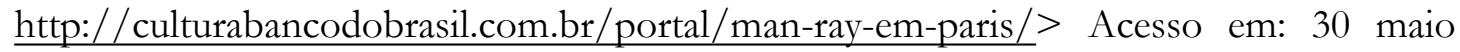
2020.

GT000 - Fotografia compósita com manipulação e efeitos digitais produzida por Antonio Miguel em 22 de Outubro de 2019. A menor delas é a famosa fotografia (1932) da fase dadaísta do fotógrafo, pintor e cineasta norte-americano Emanuel Radnitzky (1890-1976), mais conhecido como Man Ray, originalmente intitulada Les larmes (Lágrimas) e, posteriormente, Glass tears (Lágrimas de vidro). No site da WikiArt (https://www.wikiart.org/en/man-ray/larmes-tears), de onde a foto foi reproduzida, lêse: "Como se fosse um filme, [a foto Lágrimas de vidro] demonstra o interesse de Man Ray na narrativa cinematográfica. Os olhos e as pestanas cobertas de rímel da modelo estão olhando para cima, convidando os espectadores a se perguntarem para onde ela está olhando e qual é a fonte de sua angústia. A foto foi criada logo após o rompimento do artista com a sua assistente e amante, Lee Miller. Ray criou vários trabalhos na tentativa de "acabar com ela" como uma vingança contra uma amante que o abandonou (semelhante ao Objeto Indestrutive). A modelo é uma dançarina de can-can anônima". Na foto de fundo tirada por uma fotógrafa casual anônima, as falsas lágrimas de vidro da professora Virgínia Cardia Cardoso - pesquisadora do Grupo de Pesquisa História, Filosofia e Educação Matemática (HIFEM) - tentam reproduzir mimeticamente com as falsas lágrimas de vidro da dançarina de cabaré anônima fotografada por Man Ray em 1932.

MR1923 - Escultura DADA (1923) do fotógrafo, pintor e cineasta norte-americano Emanuel Radnitzky (1890-1976), mais conhecido como Man Ray, originalmente intitulada Objet à détruire (Objeto a ser destruido) e, posteriormente, Objet Indestructible (Objeto indestrutivel). No site de onde a reproduzimos (https://www.tate.org.uk/art/artworks/man-rayindestructible-object-t07614), Sophie Howarth descreve a escultura como uma "célebre combinação de um metrônomo [mecânico] com uma fotografia de um olho afixada com um clipe de papel no braço oscilante" desse instrumento do século XIX que, através de pulsos sonoros de duração previamente regulada pela distância de um peso que se desloca na haste de um pêndulo, normatiza, define e controla o tempo de um andamento musical. Por sua vez, o texto de Howarth, no site aqui referido, chama o próprio Man Ray para esclarecer o contexto de produção da sua escultura: "Eu tinha um metrônomo no lugar em que eu comecei pintar - assim como um pianista o faz quando começa a tocar - e o ruído de seu tique-taque regulava a frequência e o número das minhas pinceladas. Quanto mais rápido, mais rápido eu pintava; e se o metrônomo parasse, eu sabia que havia pintado por muito tempo, que estava me repetindo, que minha pintura não era boa e que eu a destruiria. Um pintor precisa de uma audiência; então, eu também prendi uma foto no braço giratório do metrônomo para criar a ilusão de estar sendo observado enquanto eu pintava. Um dia, não aceitei o veredito do metrônomo, o silêncio era insuportável e, como eu o havia chamado, com certa premonição, de objeto a ser destruido, eu o esmaguei em pedaços". Penso que podemos inferir desse relato que o Objeto indestrutivel de Ray teria sido uma arte casual, produzida pelo acaso, dado que ela poderia ser vista com um imprevisto pré-visto, como um imprevisto previsto que transformou um objeto a ser destruido em um objeto indestrutivel. 
TTZ 3636 - Aforismo de Tristan Tzara (1987, p. 12) no Manifesto DADA de 1918.

TTZ8880 - Com esta declaração irônica de Tzara (1987, p. 57) - que identifica a arte com uma doença da qual, por obra do acaso, não lhe será permitido falar - termina a seção denominada Pastiche do Anexo do sétimo e último Manifesto Dada intitulado $D A D A$ Manifesto sobre o Amor Débil e o Amor Amargo, que foi tornado público na Galeria Povolotzky de Paris no dia 12 de dezembro de 1920, e o seu Anexo, uma semana depois.

MF1988 - Obra intitulada "Nostalgia" do fotógrafo documental e artista gráfico iraniano contemporâneo Majid Farahani, nascido em 1988 em Teerã. Sua obra artística focaliza questões como mudanças políticas, identidade e formação de uma nova geração no Irã após a Revolução. Segundo o próprio autor, "esta colagem é feita inteiramente de peças do meu álbum de família e com objetos que encontro em minha vida cotidiana. É claro que fico de olho nas coisas: pedaços de tipografia incomum, um ticket entregue a você em alguma cidade estrangeira, um cartaz descascando da parede". Embora Nostalgia possa ser vista como uma obra artística do gênero colagem, a própria prática da colagem artística, atualmente, pode ser vista como uma prática particular dentre outras que se realizam no contexto de um movimento artístico mais amplo denominado Apropropriacionismo. Tal movimento - que perpassa, atualmente, o campo das artes visuais em geral, bem como os da literatura e poesia - se caracteriza pela apropriação ou citação intencionais de obras ou elementos de obras (formas, imagens ou estilos) de autores consagrados diversos para a produção de suas próprias obras. Fontes: (https://pt.wikipedia .org/wiki/Colagem); (https://es.wikipedia.org/wiki/Apropiacionismo); (https://commons.wikimedia.org/wiki/File:Nostalgia_110X70CM.jpg); (https://www.lensculture.com/majid-farahani). Acessos em 30 maio 2020.

KS1920 - Obra de 1920 do artista alemão Kurt Schwitters (1887-1948) denoninada Colagem. (https://en.wikiquote.org/wiki/Kurt_Schwitters). Fabiana Macchi (2009), explica do seguinte modo o nome Merz atribuído por Schwitters - artista que desempenhou um importante papel no Dadaísmo, mas que acabou criando um estilo próprio de expressão à sua produção artístico-literária: "Merz surgiu, em tese, como mais um movimento de vanguarda que preconizava uma ruptura com valores estéticos, sociais e políticos vigentes. Era, de certa forma, uma extensão do dadaísmo, do qual Schwitters, porém, fazia questão de se distanciar teoricamente. Merz nasceu da necessidade do próprio Schwitters de dar um nome para o tipo de trabalho artístico que ele fazia, e que não se encaixava nas denominações existentes. O nome Merz, que não significa nada, foi tirado de um quadro seu, uma colagem na qual a palavra Merz aparecia ao acaso, pedaço do recorte de um anúncio do Banco do Comércio (Kommerzbank). A partir de seus experimentos, sempre buscando novas formas de expressão, Schwitters chega ao primado da forma estética, não importando os materiais a serem utilizados para atingi-la. Sob o pano de fundo da destruição causada pela primeira guerra mundial e de uma sociedade necessitando de reestruturação, sua arte passa a se utilizar de dejetos, restos, pedaços de objetos — o lixo da sociedade industrial — para reestruturá-los esteticamente. Lá estão, em suas colagens e sobreposições, recortes de jornais, passagens de bonde, nacos de madeira, restos de objetos de metal etc. Ele explica: "O material utilizado é irrelevante; o essencial é a forma. Por isso utilizo qualquer material, contanto que 
a obra exija". E é precisamente neste detalhe: "contanto que a obra exija", que jaz uma das principais diferenças entre o dadaísmo e a arte Merz. O irracionalismo e a aleatoriedade, apregoados pelo dadaísmo, não eram compartilhados pela arte Meř, cujo objetivo era de produzir, sempre, um resultado estético. Segundo Ernst Schwitters, filho de Kurt, “Merz era arte, enquanto o dadaísmo era antiarte". Uma segunda diferença importante era a questão política. A arte Merr, não era engajada, no sentido restrito do termo. Kurt Schwitters distanciava-se da reivindicação DADA de estabelecer o comunismo radical como sistema político. Mas continuava ligado a Arp e Tzara, que estavam mais voltados ao abstracionismo. Sua arte era politizada em sentido amplo: Schwitters defendia que a arte deveria ser a cura do seu tempo, deveria relativizar as idéias dominantes, colocá-las em cheque, desestabilizar a estrutura vigente. Em suas soirées $M E R Z$, ao contrário das soirées $D A D A$, não havia protesto político, senão o protesto contra o comodismo e a tacanhice burguesa. Era política como crítica social e estética, crítica através da blasfêmia de usar lixo para fazer arte, através da profanação da arte burguesa” (MACCHI, 2019).

HA2001 - Obra do pintor, escultor e poeta franco-alemão Hans Peter Wilhem Arp (18861966) - um dos grandes representantes do movimento artístico dadaísta - intitulada Colagem com quadrados dispostos segundo as leis do acaso. A tela de 48,6 cm x 34,6 cm foi produzida em 1917 e encontra-se no The Museum of Modern Art de Nova Iorque. Antes de adentrarem o campo de atividade das artes visuais plásticas e escultóricas ocidentais, na passagem do século XIX para o XX, as práticas de colagem realizadas com outros propósitos sociais parecem ser tão antigas quanto a invenção do papel na China antiga. Um uso propriamente literário da colagem passou a ser feito no Japão do século XIX por parte poetas-calígrafos que passaram a escrever os seus poemas colando papéis com textos impressos sobre as superfícies de outros suportes. Fontes: (https://vanguardadadaismo.webnode.com/obras/); (https://pt.wikipedia.org/wiki/Colagem).

LT1927 - Retrato de 1927 do poeta romeno Tristan Tzara ou Samuel Rosenstock (18961963) pelo pintor e litógrafo húngaro Lajos Tihanyi (1885-1938). Tzara foi o principal articulador do movimento estético-revolucionário do Dadaísmo, que tinha por objetivo desconstruir os valores artísticos burgueses.

(https://pt.wikipedia.org/wiki/Tristan_Tzara).

LW09 - Aforismo do livro Cultura e Valor (WITTGENSTEIN, 1998, p. 29) do filósofo austríaco Ludwig Wittgenstein (1889-1951), em referência ao seu modo aforístico de se escrever filosofia.

ABC1919 - Capa do livro intitulado An Anna Blume (Para Anna Flor) do multi-artista alemão (poeta, prosador, dramaturgo, crítico, ensaísta, pintor, escultor, arquiteto, editor, publicitário, agitador cultural) Kurt Schwitters (1887-1948), originalmente publicado em 1919. (https://en.wikipedia.org/wiki/An_Anna_Blume). Para outros informes sobre o poema, ver a nota AAB1920.

AAB1920 - Poema (1919) intitulado An Anna Blume (Para Anna Flor) do multi-artista alemão (poeta, prosador, dramaturgo, crítico, ensaísta, pintor, escultor, arquiteto, editor, 
publicitário, agitador cultural) Kurt Schwitters (1887-1948). Segundo Fabiana Macchi (2009), "Kurt Schwitters aplicou o princípio da arte Merz também para a sua literatura, criando a Poesia Merv, apresentada em vários manifestos. Em analogia a seus quadros, montagens e colagens, Kurt Schwitters utilizava na literatura restos e cacos da linguagem cotidiana, da linguagem da propaganda, de slogans, ditos populares, banalidades e clichês. No posfácio da primeira edição de seu polêmico livro Anna Blume (1919), Schwitters esclarece: "A poesia Merz é abstrata. Da mesma forma que na pintura Merz, utilizo pedaços de coisas já existentes, no caso, pedaços de frases retiradas de jornais, de outdoors, de catálogos, de conversas etc., com ou sem modificações. (Isto é terrivel.) Estes pedaços não precisam ter relação com o sentido, pois o sentido não existe mais. (Isto também é terrivel.) Também não existem mais elefantes, existem apenas pedaços de poema. (Isto é horrivel). E vocês? (Levantem recursos para a guerra!). Decidam soz̨inhos o que é poesia e o que é acessório". A publicação do poema Para Anna Flor, com o subtítulo de Poema Merz I, causou um grande impacto na época. O poema foi impresso em cartazes de um metro de altura e espalhado pela cidade de Hannover. Kurt Schwitters foi severamente atacado pela crítica e tachado de demente pela burguesia letrada. Choveram cartas de protesto nos jornais, artistas saíram em defesa do autor, e o próprio Schwitters escreveu várias crônicas e cartas abertas defendendo a si próprio e atacando os críticos. Graças à polêmica, o poema tornou-se extremamente popular e arrebatou os leitores mais afeitos a novidades, que passaram a recitar o novo "poema de amor" de cor e salteado. "An Anna Blume" tornouse um mito e entrou para a história da literatura de língua alemã como um dos mais polêmicos textos de todos os tempos. Sua recepção inclui um sem-fim de paródias e citações ao longo das décadas (recentemente, inclusive por um famoso grupo de hip-hop alemão). A polêmica continuou. O poema é realmente uma grande colagem, seguindo o programa da poesia Meř, e causa, ainda hoje, estranhamento. As deformações gramaticais, falsas regências e ortografia, bem como as sequências de pronomes são elementos da poesia expressionista. Os resquícios da fala dialetal e as frases feitas tiradas de concursos de charadas ou de ditados populares são elementos Meræ. A introdução de frases que quebram a lógica semântica ou elementos que rompem com a lógica gramatical também são recursos frequentes encontrados na poesia expressionista, sem falar que tudo o que rompe com a lógica é também típico dos dadaístas. Quem é esta Anna Flor, musa de cabelos amarelos e "vestido de chita", louca e irreal, que caminha com as mãos e usa vestidos que se podem serrar? Um delírio capaz de ser apreendido apenas por 27 sentidos? Um mero deboche — os elementos grotescos, irônicos e infantis o comprovariam - do sentimentalismo romântico pequeno-burguês? Há quem diga que o amor seria sério, o pathos expressionista ainda presente no poema, para ser — é claro! — imediatamente "dadaizado" em versos" (MACCHI, 2009). A tradução do poema para o português é de Fabiana Macchi. A versão original em alemão do poema pode ser acessada em (GARBARINO, 2016, p. 31). Por sua vez, a tradução de An Anna Blume feita pelo próprio Kurt Schwitters está disponível no site seguinte, acessado em 30/04/2020: (http://www.costis.org/x/schwitters/eve.htm). "Deve-se notar que Schwitters traduziu o poema para o inglês sob o título Anna Blossom tem rodas em 1942, o que possivelmente contraria a tradução original do poema. Schwitters também traduz Anna Blume por Anna Blossom. A palavra alemã Blume se traduz por Blossom em vez de Flower. A curiosa escolha de palavras sugeriria que Anna não floresceu completamente" (GARBARINO, 2016, p. 65). Para compreendermos esta última observação de Garbarino, é preciso notar que, no 
inglês, flower é uma única planta verde, ou então, a grande copa colorida de uma planta ou árvore. Já blossom é uma coleção de flores pequenas com caule, sendo, portanto, um conjunto contável de objetos, ou então, o nome genérico para muitas flores pequenas de uma árvore qualquer.

LW282 - Conclusão do seguinte diálogo que se estabelece entre o filósofo austríaco Ludwig Wittgenstein (1889-1951) e seu interlocutor imaginário, na Passagem 282 da Parte I das Investigações filosóficas (WITTGENSTEIN, 2009): "Nos contos de fada, porém, uma panela também pode ver e ouvir!" (Com certeza; mas ela pode também falar). "Mas os contos de fada só inventam o que não é o caso; eles não são narrativas sem sentido, ou são?" - Não é tão simples assim. Seria uma inverdade ou sem-sentido dizer que uma panela fala? Temos uma idéia clara das circunstâncias em que diríamos de uma panela que ela fala?

ON10 - "Se a reta é o caminho mais curto entre dois pontos, a curva é o que faz o concreto buscar o infinito". Aforismo concretista do arquiteto modernista brasileiro Oscar Ribeiro de Almeida Niemeyer Soares Filho (1907-2012). No início dos anos de 1950, quando os poetas concretistas brasileiros começam a se agrupar em torno da revista Noigrandes, os países da Europa começavam a se recuperar dos horrores da Segunda Guerra Mundial. [...] No Brasil, na década de 1950, a emergência da poesia associou-se intimamente ao Plano Piloto para a Construção de Brasilia, elaborado pelos arquitetos brasileiros Oscar Niemeyer e Lúcio da Costa, cidade matematicamente situada no centro geográfico do país, concretizando a metáfora de ela ter sido pensada para alojar o centro do poder politico. Não foi, portanto, mera coincidência que o principal texto de poesia concreta, publicado em 1958, intitula-se Plano Piloto para a Poesia Concreta, assinado pelos poetas concretistas brasileiros Augusto de Campos (1931 - ), Haroldo de Campos (1929-2003) e Décio Pignatari (1927-2012). Foto (2019) por Antonio Miguel feita no ambiente Praça das Curvas da exposição Niemeyer em curvas, ocorrida no Shopping Iguatemi Campinas (São Paulo, Brasil) em setembro de 209, sob a produção de Thiago Carvalho e Karina Israel, promovida pelo Governo do Estado de São Paulo, por meio da Secretaria de Cultura e Economia Criativa, Iguatemi Campinas e Comgás. Fonte acessada em 30 abr. 2020: (https://pt.wikipedia.org/wiki/Concretismo).

TEK69 - Carta Arcano 69 denominada O Acaso do Tarô Egípcio Kier. Para Bibiana Rovira - praticante de Reiki e promotora de cursos sobre tarô egípcio, astrologia, xamanismo, metafísica e ioga -, a simbologia geral dessa carta nos remeteria ao "imprevisivel, à mudança de rumo do destino". Essa carta está divida em três planos simbólicos: o superior, o médio e o inferior. No plano superior, vemos, da esquerda para a direita: a letra zain do alfabeto hebraico (que simboliza o triunfo misterioso, o Eleito); o hieróglico da placenta (que simboliza o nascimento, o fruto, a matriz universal, o alimento); e o número 3, segundo o alfabeto mágico babilônio. No plano médio, vemos o corpo nú arqueado da deusa egípcia Auet (que simboliza o ventre cósmico originário do mundo) envolvendo o corpo de um jovem que caminha com os olhos cobertos por sua mão direita (que simboliza a casualidade que impera no universo, do microcosmo ao macrocosmo) sob o arco formado pelo corpo da deusa (que simboliza a separação entre o céu e a terra e seu vislumbre de eternidade). Por sua vez, no plano inferior, vemos um escorpião afastando-se do jovem, simbolizando situações ou acontecimentos fortuitos benéficos, caso a carta seja interpretada em sua posição 
normal. Se interpretada em sua posição invertida, ela simbolizaria "[...] aventura e vício desmedidos, risco nos negócios, perdas, algo que deve ser adiado para ser recebido posteriormente (ROVIRA, 2013, 163-164).

CM10 - A décima carta, denomina $A$ roda da fortuna, dentre as 21 cartas dos Arcanos Maiores do Tarô das Associações, inspirado no Tarô de Rider-Waite. O desenho da carta é do designer gráfico inglês Ciro Marchetti. Segundo, Barbara Moore - escritora norte-americana especializada em tarô - a retirada desta carta de baralho no contexto do Tarô das Associações, sugeriria que mesmo que a vida de um consultor do oráculo da vidente, no ato da consulta, esteja se transcorrendo num plano de equilíbrio e estabilidade, alguma coisa fora do controle ou da capacidade de previsão de ambos se anuncia para pôr à prova o equilíbrio e determinação do consultor (MOORE, 2014, p. 26).

CM16 - A décima sexta carta, denomina $A$ torre, dentre as 21 cartas dos Arcanos Maiores do Tarô das Associações, inspirado no Tarô de Rider-Waite. O desenho da carta é do designer gráfico inglês Ciro Marchetti. Segundo, Barbara Moore - escritora norte-americana especializada em tarô - a retirada desta carta de baralho no contexto do Tarô das Associações, sugeriria que mesmo que um consultor do oráculo da vidente sinta possuir um controle razoável de sua vida, no ato da consulta "[...] o universo o estaria relembrando de que ele não pode controlar tudo, pois a torre é como um raio que cai de repente e abala as nossas próprias estruturas". A diferença entre as cartas da Torre e da Roda da Fortuna (ver nota CM10) é que, "em vez de interferir nas circunstâncias externas de nossa vida, a Torre abalaria as estruturas de nossos sistemas de crenças” (MOORE, 2014, p. 27).

TEK77 - Carta Arcano 77 denominada A desorientação do Tarô Egípcio Kier. Segundo Bibiana Rovira - praticante de Reiki e promotora de cursos sobre tarô egípcio, astrologia, xamanismo, metafísica e ioga -, a simbologia geral dessa carta, no contexto desse tipo de tarô, nos remeteria a "bloqueios e confusões, à perda de rumo". Essa carta está divida em três planos simbólicos: o superior, o médio e o inferior. No plano superior, vemos, da esquerda para a direita: a letra Samech do alfabeto hebraico, (simbolizando o destino, o perigo); o hieróglifo do nó (simbolizando as amarras a imagens fixas e dogmáticas, "indecisão, confusão de ideias") associada à figura do babuíno que aparece no julgamento final dos mortos no tribunal de Osíris, caminhando sobre uma linha preta grossa (simbolizando "[...] a prevenção e o alerta por falta de discernimento e por bloqueio mental'); a representação do número 11 no alfabeto mágico babilônio. No plano médio, vemos "a figura de um jovem com o corpo voltado para o futuro, mas olhando para trás, indicando demora e confusão". No plano inferior, vemos vários hieróglifos "que indicam os recursos disponiveis, os mecanismos necessários para prosseguir". Quando interpretada em sua posição normal, a carta poderia indicar "a virtude bumana de reconhecer $e$ refletir, o prenúncio de obstáculos imprevistos, a confusão de ideias, a desorientação, a necessidade de ajuda". Se interpretada em sua posição invertida, ela poderia simbolizar "[...] mente perturbada, esgotamento, amnésia, obstáculos imprevistos, noticias ruins”. (ROVIRA, 2013, p. 179-180).

PK1920 - O Angelus Novus (Anjo Novo), um desenho de 1920 feito com nanquim, giz pastel e aquarela sobre papel, pelo pintor e poeta suíço-alemão Paul Klee (1879-1940) que foi adquirido pelo filósofo e crítico literário judeu-alemão Walter Benjamin, em 1921, e dele 
não mais se separou até o seu exílio na França. Atualmente, a aquarela se encontra no Museu de Israel, em Jerusalém. Na nona tese do seu ensaio Sobre o Conceito de História, Benjamin se manifesta acerca desse Angelus de Klee dizendo ser ele "um anjo que parece querer afastar-se de algo que ele encara fixamente. Seus olhos estão escancarados, sua boca dilatada, suas asas abertas. O anjo da história deve ter esse aspecto. Seu rosto está dirigido para o passado. Onde nós vemos uma cadeia de acontecimentos, ele vê uma catástrofe única, que acumula incansavelmente ruina sobre ruina $e$ as dispersa a nossos pés. Ele gostaria de deter-se para acordar os mortos e juntar os fragmentos. Mas uma tempestade sopra do paraíso e prende-se em suas asas com tanta força que ele não pode mais fechálas. Essa tempestade o impele irresistivelmente para o futuro, ao qual ele vira as costas, enquanto o amontoado de ruinas cresce até o céu. Essa tempestade é o que chamamos progresso". Segundo o filósofo e historiador judeu-alemão Gershom Scholem (1897-1982), "Benjamin tinha uma espécie de identificação mistica com o Angelus Novus e incorporou isso em seus escritos sobre o "anjo da bistória", numa melancólica visão do processo histórico como um incessante ciclo de desespero". Por sua vez, segundo o historiador francês François Hartog, "com este anjo, passa-se do gênio conquistador com olhos de águia ao anjo impotente, que contempla a acumulação das ruínas. Não se está mais no regime da historia magistra, mas tampouco no regime moderno, o da história que marcha incessantemente adiante. Precisamente, veem-se seus efeitos destruidores. [...] Lá onde queremos perceber uma cadeia de acontecimentos, um tempo linear de causas e efeitos, o anjo tem essa visão sinóptica, distante, que lhe permite perceber uma catástrofe única. Levado pelo vento do progresso, ele não pode realizar os ritos funerários apropriados e abrir a era messiânica da futura sociedade sem classes" (HARTOG, 2017, p. 121-122). De minha parte assinalo que qualquer semelhança entre essa interpretação que faz Benjamin do Angelus de Klee e a interpretação da Carta Arcano 77, denominada $A$ desorientação, do Tarô Egípcio Kier, à qual nos referimos na nota TEK77, poderia talvez (pois nunca se pode dizer com certeza) ser vista como uma brincadeira do acaso. Disponível no site seguinte,: (https://pt.wikipedia.org/wiki/Angelus_Novus). Acesso em: 30 maio 2020.

E1772 - O frontispício da Encyclopédie é uma composição alegórica na qual figuras femininas que representam a Razão e a Filosofia revelam a figura da Verdade, posicionada no centro superior da composição. Uma luz radiante emana dela, enquanto, à esquerda, a Imaginação se prepara para adorná-la com uma guirlanda de flores. Outras figuras alegóricas que representam as Artes, as Ciências e os Ofícios olham ou exibem instrumentos ou textos específicos para seus campos (MIT Libraries Exhibits, Introdução à Enciclopédia).

(http://libraries.mit.edu/exhibits/maihaugen/diderots-encyclopedie/introduction); (http://322ides.com/work/reading/DESN200-WorkSheet2.pdf). Acesso em 30 maio 2020.

JT18 - A queda de Troia do pintor alemão Johann Georg Trautmann (1713-1769) da coleção dos grão-duques de Baden, Karlsruhe. Acessível no site seguinte: (https://pt.wikipedia.org/wiki/Guerra_de_Troia). Acesso em 30 maio 2020.

CPL71 - Ícaro e Dédalo, óleo sobre tela (1879) do pintor francês Charles Paul Landon (17601826). (https://pt.wikipedia.org/wiki/Charles_Paul_Landon). Dédalo e Ícaro em cena, 
momentos antes da tragédia prevista por Dédalo e da transgressão das leis da natureza por Ícaro em seu desenfreado desejo tecnológico de voar com as asas dos pássaros ou, talvez. (pois nunca podemos dizer com certeza), com as asas dos anjos.

EM943 - O anjo da morte de Evlyn de Morgan (1855-1919). Óleo sobre tela de 1881. Disponível em:

(https://pt.wikipedia.org/wiki/Ficheiro:Evelyn_De_Morgan_-_Angel_of_Death.jpg).

Acesso em 30 maio 2020.

BP1825 - Um anjo da guarda do pintor e artista gráfico alemão Bernhard Plockhorst (18251907). "Plockhorst era membro do movimento Nazareno, uma escola de arte romântica alemã que recorria a tópicos de arte medieval e religiosa". [...] "Um anjo da guarda é um anjo designado para proteger e guiar uma pessoa, grupo, reino ou país em particular. A crença nos anjos da guarda pode ser rastreada por toda a antiguidade. O conceito de anjo da guarda está presente nos livros da Bíblia Hebraica e do Antigo Testamento, e seu desenvolvimento é bem marcado. Esses livros descreviam os anjos como ministros de Deus que cumpriam suas ordens e, às vezes, eram enviados ao mundo por Deus para cumprir tarefas especiais em relação aos seres humanos e a assuntos mundanos: "Enviarei um anjo para protegê-lo no caminho e para te confuzir ao lugar em que te preparei" (Êxodo 23:20); em Gênesis 1819, os anjos não apenas agiram como executores da ira de Deus contra as cidades, como também libertaram Ló do perigo; em Êxodo 32:34, Deus disse a Moisés: "Meu anjo irá adiante de ti’. Fontes: (https://en.wikipedia.org/wiki/Guardian_angel);

(https://jigarodrigues.files.wordpress.com/2013/10/anjodaguarda.jpg); (https://en.wikipedia.org/wiki/Bernhard_Plockhorst), acessadas em 30 maio 2020.

PE400 - Trata-se do segundo de um conjunto de 14 poemas intitulados Jeux vagues de la poupée (ÉLUARD, 1968, p. 1007-1010). Em 1938, o poeta francês Paul Éluard selecionou 14 fotografias da boneca do artista plástico alemão Hans Bellmer ilustrando-as com curtos poemas reunidos e publicados em 1968, em seu Ouvres Completes. Só em 1949 o trabalho colaborativo completo entre Éluard e Bellmer, intitulado Les Jeux de la poupée (Os jogos da boneca), veio a ser publicado (TAYLOR, 2000, p. 98 e p. 251).

MM19 - A atriz brasileira Fernanda Montenegro em uma foto de 2019 de Mariana Maltoni. A foto aparece na capa da Revista dos Livros Quatro cinco um, ano 3, n. 27, 2019. Sob a foto da capa, aparece o enunciado "Sobre livros e bruxas", em referência ao conjunto de quatro matérias sobre essa temática, respectivamente intituladas: Aprendizes de feiticeira, por Paula Carvalho; Vocação inarredável, por Gregorio Duvivier; A menina que roubava a cena, por Sérgio Augusto; As bruxas estão soltas, por Rui Luis Rodrigues.

JHW18 - O ciclope Polifemo, óleo sobre tela do pintor alemão Johann Heinrich Wilhelm Tischbein (1751-1829), conhecido como Goethe Tischbein. Polifemo é uma entidade mitológica com a qual, segundo a Ilíada de Homero, Ulisses e seus companheiros teriam se defrontado no retorno de Troia à Grécia. Gigante imortal com um só olho no meio da testa, Polifemo trabalhava como ferreiro com Hefesto, o deus grego da tecnologia. Segundo o canto IX da Odisseia de Homero, a vida de Polifemo é interrompida quando o 
Odisseu (Ulisses, na mitologia romana) e seus companheiros, em viagem de volta de Tróia para Ítaca, entraram na caverna na qual Polifemo vivia com suas ovelhas buscando por comida. Mas quando o gigante regressa e percebe que sua morada havia sido invadida, ele fecha a caverna com uma rocha enorme, aprisiona os marinheiros e começa a comer dois deles de cada vez. Odisseu maquina um plano para os demais escaparem e oferece vinho a Polifemo, tentando embebedá-lo. Este lhe pergunta por quem lhe oferece a bebida e Odisseu lhe responde: "foi Ninguém". Quando o gigante adormece, os marinheiros afiam uma vara e a espetam no olho do ciclope, cegando-o. No dia seguinte, Polifemo abre a caverna para deixar sair as ovelhas, verificando com o tato se eram realmente ovelhas ou os prisioneiros. Porém estes escondem-se, agarrando-se por baixo das ovelhas e conseguindo escapar. Ao dar-se conta da fuga, Polifemo grita aos seus companheiros ciclopes dizendo-lhes que "Ninguém o tinha cegado", mas estes o ignoram. De volta a seu navio, Odisseu zomba de Polifemo, gritando-lhe que não tinha sido Ninguém que o havia cegado, mas sim Odisseu. Furioso, Polifemo atira grandes rochas ao acaso para o mar. Disponível em: < https://pt.wikipedia.org/wiki/Ciclope>. Acesso em 30 maio 2020.

JC00 - A pítia de Delfos (1891), óleo sobre tela do pintor inglês John Maler Collier (18501934). Pítia ou pitonisa era o nome que recebiam as supremas sacerdotisas do oráculo da cidade de Delfos, no mundo grego antigo. Ao longo de mais de mil anos, elas foram eleitas como porta-vozes dos conselhos e desejos do Deus-Sol Apolo, o qual, por sua vez, supostamente, transmitia as vontades de Zeus, seu pai. Às pitonisas era atribuído o poder e o papel de estabelecerem ligação entre os deuses e a humanidade, uma vez que elas eram eleitas por suas supostas habilidades especiais de entrarem em transe e preverem o futuro. Essas mulheres, que passavam os seus dias reclusas no templo de Delfos cultuando o deus Apolo, exerceram uma enorme influência indireta na elaboração de políticas governamentais, desde a construção de cidades até a deflagração de guerras. Fontes acessadas em: 30 maio 2020:

$<$ https://en.wikipedia.org/wiki/John_Collier_(painter); ki/Oracle_of_Delphi ); (https://www.sermujerayeryhoy.com/2018/09/29/la-pitia-dedelfos/ ).

FG4321 - A imagem mostra estudos realizados pelo antropólogo, meteorologista, matemático e estatístico inglês Francis Galton (1822-1911), inventor da impressão digital e criador da palavra engenia (GALTON, 2005), para classificar, ordenar e indexar marcas características dos dedos das mãos, segundo a maior ou menor variação que apresentam em relação às de outros dedos tomados como padrões (MIGUEL, 2014). Fonte da imagem, acessada em 30/05/2020:

(http://www.eugenicsarchive.org/html/eugenics/static/images/2191.html).

DMP18 - Versos do poeta bloguista internáutico brasileiro Davi Melo da Penha (PENHA, 2018).

JGP442 - Versos da canção Passarinheiro (GARFUNKEL, 1984).

LD00 - As linhas do destino em uma mão esquerda que perdeu seu corpo. 
HT12 - Helena de Troia. Óleo sobre tela de Evlyn de Morgan (1855-1919). Obra de1898, disponível em:

(https://pt.wikipedia.org/wiki/Il\%C3\%ADada\#A_guerra_de_Troia). Acesso em: 30 maio 2020.

JSGW01 - Capa do livro A Grande Guerra (SACCO, 2013) do jornalista e artista de quadrinhos Joe Sacco, nascido na República de Malta em 1960. Imagem extraída de (ESLAVA, s/d, p. 6).

JS1926 - Desenho do jornalista e artista de quadrinhos Joe Sacco, nascido na República de Malta em 1960, que retrata os preparativos nas trincheiras antes do início da Batalha de Somme - ocorrida entre 01 de julho e 18 de novembro de 1916, nas margens do rio Somme, no nordeste da França - travada entre a França e o Império Britânico contra o Império Alemão, na Primeira Guerra Mundial. Desenho extraído de (ESLAVA, s/d, p. 22). Em seu livro $A$ ética de Wittgenstein e a guerra moderna, Nil Santiáñez, professor de Espanhol e de Estudos Internacionais junto à Saint Louis University, defende o ponto de vista de que a noção de inefabilidade que caracteriza as reflexões éticas do Wittgenstein do "Tractatus" constitui uma ferramenta central para a investigação e interpretação dos silêncios éticos subjacentes a relevantes representações culturais da Primeira Guerra Mundial, dentre os quais se destaca a narrativa gráfico-imagética The Great War (SACCO, 2013) do jornalista e artista de quadrinhos Joe Sacco. Pois, para Santiáñez (2018, p. X), “[...] esses silêncios não são apenas o resultado de um problema epistemológico - um problema derivado da dificuldade em expressar a experiência de uma guerra que muitos consideraram praticamente indizível. Além disso, esses silêncios estão carregados de valor ético”. Acerca da obra imagética de Sacco, Santiáñez (2018, p. 13) diz que "para alguns escritores, artistas e pensadores [que participaram direta ou indiretamente da guerra], o colapso ético tornouse inexprimível. Expressando silenciosamente esse colapso ético, ou seja, empregando uma linguagem do silêncio para comunicar verdades éticas, Sacco segue uma noção de ética apresentada por Ludwig Wittgenstein - uma noção que nasceu precisamente dessa mesma guerra representada por Sacco. Ele apresenta a guerra conectando o dilema epistemológico ao silêncio ético de Wittgenstein, ou, para colocar em termos mais gerais, ao silêncio ético filosófico - filosófico, porque esse silêncio específico relacionado à ética surge da reflexão filosófica sobre os limites da linguagem. Do mesmo modo que a Grande Guerra produziu um dilema epistemológico, criou também a condição de possibilidade de deslocar a reflexão ética da palavra falada ou escrita para o silêncio”. Por sua vez, acerca do livro de Santiáñez, Vincent Sherry - professor da Washington University e autor do livro A Grande Guerra a Linguagem do Modernismo - afirma ser ele "uma análise eloquente e incisiva do impacto da guerra no pensamento ético e linguístico de Wittgenstein. Mais importante, este estudo localiza em Wittgenstein um ponto de referência central para uma ampla gama de ficções literárias da guerra, para as quais revela uma nova e poderosa coerência" (SANTIÁÑEZ, 2018).

SA15 - Túmulos de soldados mortos na Primeira Guerra Mundial (1914-1918) no cemitério americano Aisne-Marne em Belleau, França. O cemitério está localizado no sopé 
da colina onde foi travada a batalha de Belleau Wood, na qual muitos soldados americanos morreram. Neste cemitério também estão enterrados muitos soldados mortos na batalha de Château-Thierry. Fontes acessadas em 30 maio 2020:

(https://en.wikipedia.org/wiki/Aisne-Marne_American_Cemetery_and_Memorial); (https://ultimosegundo.ig.com.br/mundo/sacrificios-da-primeira-guerra-ressoamnovamente-em-campos-franceses/n1597365785876.html).

TP13 - Capa do DVD do documentário produzido pelo diretor cinematográfico britânico Tony Palmer (PAMER, 2013) em comemoração ao centésimo aniversário do nascimento do compositor britânico Benjamin Britten (1913-1976). Na capa, que evoca visualmente o Noturno de Britten, pode-se ler também a seguinte adevertência pacifista do compositor: "Meu tema é a guerra e o lamento da guerra. A poesia está no lamento. Tudo o que um poeta pode fazer é alertar". Um noturno é uma composição musical inspirada pela noite. O Noturno (Opus 60) de Britten é uma canção para tenor e sete instrumentos musicais. A canção evoca o sono e a escuridão tanto em sentido literal quanto figurado. Fontes acessadas em 30/05/2020:

[https://en.wikipedia.org/wiki/Nocturne_(Britten)]. (https://www.youtube.com/watch?v=tomfSyXNcDc).

LW88 - Com esta declaração aforística - confiante e sincera -, o filósofo austríaco Ludwig Wittgenstein (1889-1951) termina o seu Tractatus Logico-Philosophicus (WITTGENSTEIN, 2010, aforismo 7).

GGJD - Versos da canção $A$ paそ (GIL; DONATO, 1986) dos compositores e cantores brasileiros Gilberto Gil e João Donato, composta em 1986. Segundo Gil, teria sido a calma e pacífica imagem de João Donato dormindo em plena luz do dia que teria chamado a sua atenção para o sentido da paz e o teria remetido à lembrança da contradição entre guerra e paz manifesta já no título do livro "Guerra e Paz" (1869) do escritor russo Leon Tolstói (1828-1910), mote que perpassa metaforicamente a letra de toda a canção. Fontes (https://pt.wikipedia.org/wiki/A_Paz_(canção_de_Gilberto_Gil); (http://www.gilbertogil.com.br/sec_disco_info.php?id=383\&letra). Acesso em 30 maio 2020.

TTZ 9090 - Passagem do “Manifesto DADA de 1918” (TZARA, 1987, p. 17).

TTZ674 - Passagem do "Manifesto DADA de 1918” (TZARA, 1987, p. 16).

TT214 - Passagem do “Manifesto DADA de 1918” (TZARA, 1987, p. 17).

RM76 - Primeiro parágrafo do livro "Um homem sem qualidades” (MUSIL, 2015) do escritor austríaco Robert Musil (1880-1942). O que se segue é uma colagem de fragmentos justapostos de impressões pessoais interativas dos internautas J: Júlio (19/02/2019), C: Carlos (09/09/2017), JR: José Ricardo (29/12/2016), GB: Gabi (03/11/2016), G: Gininha (09/04/2010) e AM: Alan Mello (08/09/2014) acerca dessa obra literária. (https://www.skoob.com.br/livro/resenhas/10046/recentes/). 
JR - O romance se desenvolve em Viena, fim do Império Austro-Húngaro, nos anos que antecederam a Primeira Guerra. Ele foi escrito e reescrito durante mais de 20 anos por Musil, e ainda assim permaneceu inacabado diante da morte repentina do autor. O enredo traz como protagonista Ulrich, cujo sobrenome não é revelado para preservar a privacidade da família. Ulrich tem 32 anos de idade e já tentou seguir 3 profissões - militar, engenheiro e matemático - para se tornar um homem, como ele mesmo diz, extraordinário. Contudo, não obteve sucesso em nenhuma delas. Em razão disso, decide tirar um ano de férias de sua vida a fim de se reencontrar.

G - No início, pensei tratar-se de um registro romanceado da decadência do império austro-húngaro, mas logo se percebe tratar-se de um estilo literário denso, transcendendo uma mera narrativa, até mesmo um romance.

AM - Romance-Ensaio ou Bildungsroman (Romance de Formação) são termos que cabem bem para descrever o que é esse espetáculo literário, mas concordo com o Thomas Mann que, com base na seguinte citação de Goethe, diz de tal livro não poder mais ser ele visto como um romance: "O espécime perfeito supera necessariamente sua espécie, para vir a ser algo novo e incomparável!”.

J - Logo no início somos introduzidos a Ulrich, o próprio homem sem qualidades, que obtém tal apelido dos amigos por não estar apegado as virtudes e normas sociais que regem a vida de seus pares. Ele é descrito como sendo indiferente a todos ao seu redor, vivendo a vida em um limbo analítico. É nas interações de Ulrich com os demais personagens que encontramos a medula da obra.

GB - O escritor e tradutor gaúcho Marcelo Backes sintetizou muito bem o seu conteúdo: “A ação transcorre na Áustria imperial, dissimulada sob o nome de Kakânia. O romance constitui um vigoroso painel da existência burguesa no início do século XX e antecipa, de certa forma, as crises que a Europa viveria apenas na segunda metade daquele mesmo século. A obra é o retrato ficcional apurado de um mundo em decadência. Elaborado com fortes doses de sátira e humor, o livro é uma bola de neve de ações paralelas que engendra um romance inteiriço, ainda que multiabrangente, pluritemático e panorâmico. Ulrich - o homem sem qualidades - faz três grandes tentativas de se tornar um homem importante. A primeira delas é na condição de oficial, a segunda no papel de engenheiro (vide a carreira do próprio Musil) e a terceira como matemático, exatamente as três profissões dominantes - e mais características - do século XX. Os três ofícios são essencialmente masculinos e revelam o semblante de uma época regida pelo militarismo, pela técnica e pelo cálculo que, juntos, acabaram desmascarando o imenso potencial autodestrutivo da humanidade".

G - Depois de muito viajar pelo mundo, Ulrich retorna à Viena, convive nas altas rodas de Viena e, aí, surgem personagens cônscios de um poder com enorme influência no mundo das economias, das políticas, porém um poder que começa a escapar daquilo que um dia constituiu o grande Império Austro-Húngaro. Esses personagens, caquéticas figuras em declínio, face a novas forças mundiais que reivindicam um novo status na ordem das coisas, aparecem, com seus conceitos rigidamente estabelecidos, suas ilusões de poder e que Musil retrata com aguda ironia.

J - Para mim a genialidade da obra está no desenvolvimento psicológico e filosófico de cada personagem, feita de maneira singular e criando indivíduos que são intelectualmente complexos. São nas interações, nos diálogos socráticos que Musil mostra sua habilidade como criador. Um dos grandes veículos na trama é a Ação Paralela, uma organização feita 
para mostrar a superioridade moral e intelectual do povo Austríaco sobre o resto da Europa. Nesse meio transitam diplomatas, escritores, militares, condes e todo tipo de personagem da aristocracia austríaca, com o objetivo de se unirem para criar um grande evento - ou uma grande ideia - que irá honrar os 70 anos de reinado do imperador Franz Joseph. Mas obviamente a motivação é sobrepujar as demais nações, principalmente a Alemanha. A ironia fica pelo conhecimento que temos dos eventos que irão se seguir (mas que na obra nunca chegam a acontecer) na Europa. É triste que a obra não tenha uma conclusão. Mas $O$ Homem sem qualidades é o maior exemplo possível de que a jornada tem mais importância que o destino.

C - O autor vai costurando fatos em torno de um mundo em seu caminho inexorável para o conflito e a guerra, a desconstrução de uma tradição monárquica, a modernidade com toda o seu frenesi e desconforto e uma pouco definida nova ordem social. Personagens intensos e densos caminhando para uma tensão incestuosa, atores sociais desfilando vaidades e inseguranças, pensadores mergulhados em conflituosas reflexões e debates (pacifismo x armamentismo, modernidade x tradição, fé x lógica, pensamento x ação, sensualidade $\mathrm{x}$ renuncia) vai rascunhando o perfil do ser de uma época de transição, fim e começo, mas sobretudo de perplexidade (ou antes, o seu contrário, a indiferença).

J - Além disso temas como infidelidade, racismo, antissemitismo, religião, pátria e cultura podem ser amplamente explorados.

JR - O homem sem qualidades não é somente Ulrich. Ele representa o ser humano que, não obstante tenha as condições para ser um cidadão de bem, acaba por não alcançar aquilo que, no fundo, pode-se nominar como paz de espírito - ataraxia para os gregos ou, se preferir, felicidade interior. O livro mostra como a sociedade costuma esconder a sujeira debaixo do tapete. Seu autor, contudo, não se contenta apenas com isto. Ele localiza esses tapetes e mostra tudo o que está ali embaixo e que muitos se recusam a ver. Mostra, ainda, a emergência de uma sociedade dominada pela técnica e que esta mesma técnica mais afasta do que aproxima o ser humano de si próprio. O homem sem qualidades evidencia os limites da razão para lidar com os sentimentos mais íntimos que permeiam o ser humano.

JR - O homem sem qualidade é aquele que busca sentido em sua vida, mas não encontra um modelo seguro, satisfatório e suficiente para trilhar seus passos; para se preencher como pessoa. É o ser humano em crise, sem certezas e, sobretudo, sem referenciais com os quais se identifique. Não por acaso, Ulrich, embora contasse com os requisitos para seguir as profissões que tentou, não obteve êxito em quaisquer delas. Dito de outro modo, Ulrich não se ajustou ao modelo social existente, o que o levou a sair à procura de algo que ele nem sabe o que é e tampouco onde pode encontrá-lo.

MA28 - Capa da 1a. Edição do livro Macunaíma: o herói sem nenhum carácter (ANDRADE, 1985) do poeta, escritor e crítico literário brasileiro Mário Raul Morais de Andrade (1893-1945), publicado em 1928, acessível no site seguinte visitado em 30/05/2020: (https://pt.wikipedia.org/wiki/Macuna\%C3\%ADma). Deste site extraímos o seguinte comentário sobre essa obra: "O livro hoje é largamente conhecido no Brasil, e seu protagonista saiu das suas páginas para ir viver no imaginário coletivo da nação, tornando-se um ícone popular. Na mídia e na cultura popular formou-se uma persistente imagem de Macunaíma como um retrato do "brasileiro médio" e seu modo de viver e 
entender o mundo, geralmente enfatizando traços negativos de preguiça, inconstância, libertinagem, covardia e pouca confiabilidade, mas para a maioria dos críticos recentes essa visão é um estereótipo pouco fiel à realidade. É verdade que a acidentada e excitante carreira do herói acaba em uma grande derrota: ele perde tudo ao que dava valor e tudo que dava sabor à sua existência, perde seus amores, sua família, seu império, e toda sua tribo se extingue; no final, solitário e desiludido, deixa o mundo e vai para o céu, transformando-se numa constelação. Porém, reivindicando a diversidade e miscigenação que marcaram a formação do país, normalizando o imprevisto, e incorporando a liberdade, a imaginação, a poesia e o maravilhoso ao cotidiano, ele tem sido entendido pelos pesquisadores muitas vezes como um anti-herói, um símbolo da resistência ao colonialismo, à massificação, à homogeneização e à higienização étnica e cultural, aos preconceitos e hegemônicos; um contraponto ao racionalismo frio e desumanizante, ao mundo das convenções, das regras fixas, dos horários rígidos e dos valores supostamente eternos e universais, cuja mensagem permanece viva e pertinente para o presente. A controvérsia, de fato, cercou a obra desde seu lançamento em 1928, surgindo em um momento em que os intelectuais modernistas procuravam tanto descobrir como redesenhar a "verdadeira" identidade nacional, trabalhando num contexto conservador, enfrentando a herança ainda muito viva do passado monárquico e colonial, e lutando para abrir um caminho legítimo e novo para um futuro que não discerniam com clareza".

RM77 - Fragmento do livro O homem sem qualidades (MUSIL, 2015) do escritor austríaco Robert Musil (1880-1942).

RM78 - Fragmento do livro O homem sem qualidades (MUSIL, 2015) do escritor austríaco Robert Musil (1880-1942).

MA5 - Passagem do livro "Macunaíma" (ANDRADE, 1985, capítulo V) em que o herói sem nenhum caráter inventado por Mário de Andrade manifesta uma atitude de suspeição irônica em relação às máquinas e à colonização de humanos por máquinas semelhante àquela que Ulrich, o homem sem qualidades do romance de Robert Musil, na passagem que destacamos na nota RM78, demonstra em relação às máquinas, à matemática e à ciência. É interessante comparar também essas atitudes com a crítica explícita e irônica que Tristan Tzara remete, nos Manifestos DADA, à lógica, à matemática e à ciência, sobretudo em seus usos normalizadores da arte. Segundo Remo Bodei (2018, p. 181), professor de história da filosofia na Universidade de Pisa, na Antiguidade ocidental, o termo mekhané - do qual derivou a palavra latina machina e a portuguesa máquina, e, por extensão, os adjetivos mecânico ou maquinal e o substantivo mecânica, para designar o estudo das técnicas e dos mecanismos - significava astúcia, engano, artifício. É com tal significado que, na passagem 173-184 do Canto VIII da "Ilíada", Homero mobiliza o verbo maquinar, no trecho em que Heitor - o grande herói troiano que garante a segurança da cidade exorta troianos e outros povos aliados a resistirem destemidamente aos invasores gregos (aqueus): “Troianos, lícios e dardânios, guerreiros mano a mano: sede varões, amigos, e mentalizai bravura impetuosa. Reconheço que o Zeus Cronida, benevolente, me assinala vitória e grande glória; para os dâneos, desgraça. Tolos, eles que maquinaram essa muralha 
delicada, malograda. Ela não conterá o nosso ímpeto: os cavalos fácil pularão sobre o fosso cavado. Mas quando eu estiver nas côncavas naus, que então se mentalize o fogo abrasivo para que eu queime as naus e mate os argivos junto a elas, aterrorizados pela fumaça". Foi acionando tal máquina ou astúcia artiticial e, portanto, tal arte ou técnica, que Ulisses engana o gigante Polifemo para salvar a sua vida e a de seus companheiros, no comentário que fizemos na nota JHW18. Mais geralmente, é sempre acionando tais maquinarias artísticas ou artificiais que Ulisses se safa de todas as armadilhas que lhe preparam os deuses e o destino em sua aventura tortuosa de retorno à Ítaca, tal como o descreve poeticamente - isto é, maquinalmente - Homero em sua Odisséia. Isto poderia nos remeter, é claro, à máquina dadaísta de fazer poemas de Tzara e às engenhosas maquinarias acionadas pelo (anti)herói sem caráter Macunaima para livrar-se das armadilhas que lhe preparam os seres fantásticos com os quais se confronta em sua saga descolonialista que lhe garanta o direito ao não-trabalho, à preguiça, aos prazeres de suas brincadeiras amorosas e a outras deliciosas traquinagens descapitalizadoras. Devemos também nos lembrar de que as três grandes tentativas frustradas que faz Ulrich, o homem sem qualidades de Musil, para se tornar um homem de qualidade são: tornar-se um militar, tornar-se um engenheiro e tornar-se um matemático.

AT42 - Silogismo sarcástico que o matemático britânico Alan Turing (1912-1954) inventor de uma máquina precursora do computador moderno que quebrou o código da Enigma, a máquina de encriptação utilizada pelos alemães na Segunda Guerra Mundial para codificar e decodificar mensagens - incluiu em uma carta ao seu amigo Norman Routledge, em 1952, dois anos antes de cometer suicídio "[...] mordendo uma maşã embebida em cianeto, em aparente reverência a um dos seus filmes favoritos, a versão de Branca de Neve e os Sete Anões feita pelos estúdios Disney". Devido à sua homossexualidade, "Turing havia sido condenado pela Emenda Labouchere (1885) que considerava crime "atos de grande indecência não especificados entre homens adultos, em público ou privadamente, e que continuaria em vigor, na Inglaterra, até 1967. Como alternativa a uma condenação à prisão, ele foi forçado a submeter-se a uma bumilhante série de injeções de estrogênio com o objetivo de curá-lo (LEAVITT, 2007, p. 1-5). É interessante comparar o uso irônico feito por Tzara, na nota TTZ943, de seu silogismo colonial para denunciar o formalismo e o comércio no campo das artes, com o uso sarcástico e igualmente falacioso feito por Turing do seu silogismo, no caso, para expressar o seu "temor de que a sua homossexualidade fosse utilizada não apenas contra ele, mas também contra as suas ideias". Isso porque, após ter publicado, em 1936, o artigo "On computable numbers, with an Application to the Entscheidungsproblem" ("Sobre números computáveis, com uma aplicação ao Problema da Decisão") - no qual ele provava ser possível construir uma máquina, bem como descrevia o seu processo de construção, que realizasse qualquer tarefa que também pudesse ser realizada por humanos, desde que fossem dadas à máquina instruções explícitas, isto é, um algoritmo , para realizar a tarefa -, Turing também escreveu, em 1951, um contundente artigo não técnico intitulado "Pode uma máquina pensar ?" (TURING , 1969), no qual ele enunciava e desconstruía , um a um, diferentes tipos de argumentos questionadores da tese de que uma máquina computacional, tal como ele havia proposto, também podia pensar, tal como humanos. Desde a década de 1940, essa tese vinha recebendo inúmeras críticas de setores conservadores da sociedade britânica, talvez porque, destaca Leavitt $(2007$, p. 3) a defesa 
que fazia Turing de um “[...] tratamento justo em relação às máquinas contivesse uma sutil crítica às normas sociais que negavam a uma outra população - a dos homens e mulheres homossexuais - o direito a uma existência legal e legítima".

RM100 - Fotografia por Antonio Miguel. O texto sobreposto à foto são palavras da Rainha Malvada no filme "Branca de Neve e os sete anões" de Walt Disney, cuja primeira exibição ocorreu no ano de 1938.

RM92 - A traição das imagens, tela de 1929 do pintor belga Rene Magritte (1898-1967). A proposição Isto não é um cachimbo abaixo da imagem de um cachimbo nessa pintura de Magritte compõe um silogismo que pode ser visto como uma versão plástico-visual do paradoxo do mentiroso. Ver Nota TTZ943. (https://www.renemagritte.org/images/ paintings/the-treachery-of- images.jpg). Acesso em 30 maio 2020.

\section{Referências}

ANDERSON, Keith. Encarte textual. CD-Áudio Britten War Requiem. Germany: HNH International Ltd., 1996.

ANDRADE, Mário de. Macunaíma: o herói sem nenhum caráter. 2. ed. Belo Horizonte: Itatiaia, 1985.

ANDRADE, Oswald. Manifesto Antropófago. Revista de Antropofagia, Ano 1, N. I, maio de 1928. Disponível em: <http://www.ufrgs.br/cdrom/oandrade/oandrade.pdf>. Acesso em: 15 abr. 2020.

BODEI, Remo. Língua italiana: uma filosofia inclusive para os não filósofos. In: CASSIN, B. (Coord.); SANTORO, F.; BUARQUE, L. (Orgs.). Dicionário dos Intraduzíveis. v 1. Belo Horizonte: Autêntica, 2018. p. 161-185.

BRITTEN, Benjamin. War Requiem. CD-Áudio, 2 discos. Nigel Boddice, Conductor of Chamber Orchestra; Martyn Brabbins, Conductor of BBC Scottish Symphony Orchestra. Germany: HNH International Ltd, 1996.

DIDEROT, Denis.; d'ALEMBERT, Jean Le Rond. Enciclopédia, ou Dicionário razoado das ciências, das artes e dos ofícios. v. 3: Ciências da Natureza. 1. ed. Organização e tradução Pedro Paulo Pimenta, Maria das Graças de Souza. São Paulo: Editora Unesp, 2015.

DOSTOIEVSKY, Fyodor. Um jogador: apontamentos de um homem moço. Tradução, posfácio e notas de Boris Schnaiderman; xilogravuras de Axel Leskoschek. São Paulo: Editora 34, 2004. 
ÉLUARD, Paul. Oeuvres completes. v. 1. Paris: Gallimard, 1968.

FEENBERG, Andrew; FREEDMAN, Jim. When poetry ruled the streets: the French May events of 1968. Foreword by D. KELLNER. New York: State University of New York Press, 2001.

ESLAVA, Luis. Joe Sacco's The Great War: Violence and the Artefactuality of International Legal History. s/d. Disponível em:

$<$ https://core.ac.uk/download/pdf/46521268.pdf>. Acesso em: 30 maio 2020

GALTON, Francis. Finger Prints: The Classic 1892 Treatise. New York: Dover Publications, 2005.

GARBARINO, Kaitlyn. M. L. Kurt Schwitters' An Anna Blume and the Gendered Politics of Printmaking in Weimar Germany. 2016. Master of Arts, 106p. Department of Art History \& Archeology, Faculty of the Graduate School, University of Missouri-Columbia, Missouri, 2016. Disponível em:

< https://mospace.umsystem.edu/xmlui/bitstream/handle/10355/56059/research.pdf?s equence $=2 \&$ is Allowed $=\mathrm{y}>$, Acesso em 30 maio 2020 .

GARFUNKEL, J. Passarinheiro. Faixa 3 do CD-R Tarancon em Amazona Vingadora. São Paulo: Tarinã Promoções Culturais Editora e Gravadora Ltda. 1984. Fonte: < http://trem-de-minas.blogspot.com/2008/02/tarancon-amazona-vingadora1984.html>, Acesso em: 30 maio 2020.

GIL, Gilberto. Ele falava nisso todo dia. Faixa 6 do Álbum de Vinil intitulado Gilberto Gil ou Frevo rasgado. Gravadoras: Philips Records, Water Music e Universal Music. 1968. Disponível em:

(https://pt.wikipedia.org/wiki/Gilberto_Gil_(álbum_de_1968)\#Ficha_técnica). Acesso em: 30 maio 2020.

GIL, Gilberto.; DONATO, João. A paz. Rio de Janeiro: Gege Edições / Preta Music (EUA \& Canada) / C Acre Editora Musical LTDA, 1986.

GRAUNT, John. Natural and Political Observations made upon the Bills of Mortality. London: Printed by John Martyn, Printer to the Royal Society, at the Sign of the Bell in St. Paul's Church-yard, 1665.

HALD, Anders. A History of Probability and Statistics and Their Applications before 1750. New Jersey: John Wiley \& Sons, Inc, 2003.

HARRIS, J. Rendel. A further note on the Cretans. The Expositor, Vol. 3, Seventh series. p. 332-337, 1907. London: Edited by Robertson Nicoll, M.A, LL.D. Disponível em: < https://archive.org/details/expositor190703coxs/page/336/mode/2up> Acesso em 30 maio 2020. 
HARTOG, François. Crer em História. Belo Horizonte: Autêntica Editora, 2017.

HOMERO. Ilíada. Tradução de Christian Werner. São Paulo: Ubu Editora/SESI-SP Editora, 2018.

JARMAN, Derek. War Requiem. 92 minutos. Reino Unido: Magnus Opus, 1988.

KASNER, Edward.; NEWMAN, James. Matemática e Imaginação. Tradução de Jorge Fortes. Rio de Janeiro: Zahar Editores, 1968.

LA BRUYÈRE, Jean de. Les Caractères. Paris: In Livro Veritas. Disponível em: $<$ http://bibliotecadigital.puc-campinas.edu.br/services/ebooks/Jean\%20de\%20la\%20Bruyere-1.pdf), acessado em 30/05/2020.

LAPLACE, Pierre-Simon. Essai Philosophique sur les probabilités. Paris: $\mathrm{M}^{\mathrm{ME}} \mathrm{V}^{\mathrm{X}}$ Courcier Imprimeur-Libraire pour les Mathématiques, quai des Augustins, n. 57, 1814.

LEAVITT, David. O homem que sabia demais: Alan Turing e a invenção do computador. Tradução Samuel Dirceu. São Paulo: Novo Conceito Editora, 2007.

MACCHI, Fabiana. Kurt Schwitters, o dadaista que era Merz. Sibila: Revista de poesia e crítica literária. São Paulo, ano 19, abril de 2009. Disponível em:

$<$ http://sibila.com.br/poemas/kurt-schwitters-o-dadaista-que-era-merz/2790>, Acesso em: 30 maio 2020.

MALLARMÉ, Stéphane. Un coup de dés jamais n'abolira le hasard Source gallicalabs.bnf.fr / Bibliothèque nationale de France. Gallica Bibliothèque Numérique, s/d. Disponível no site seguinte:

<https://upload.wikimedia.org/wikipedia/commons/e/e1/Un_coup_de_dés.pdf $>$. Acesso em: 30 maio 2020:

MICHELET, Jules. História da Revolução Francesa: da queda da Bastilha à Festa da Federação. São Paulo: Companhia das Letras, 1989.

MIGUEL, Antonio. Infâncias e Pós-colonialismo. Educação \& Sociedade, Campinas (SP), v. 35, n. 128, p. 857-879, jul-set. 2014.

MIGUEL, Fernanda V.C. \& MIGUEL, Antonio. Uma terapia do noturno a partir do War Requiem de Derek Jarman. Aletria, Belo Horizonte, v. 25, n. 1, p. 189-207, jan-abr 2015.

MOORE, Barbara. O tarô das associações: um guia de leitura e interpretação inspirado no Rider-Waite. Arte de Ciro Marchetti. Tradução de Marta Rosas. São Paulo: Pensamento, 2014. 
MUSIL, Robert. O homem sem qualidades. Tradução Lya Luft e Carlos Abbenseth. Rio de Janeiro: Nova Fronteira, 2015.

NAGEL, Ernest. O Significado de probabilidade. In: NEWMAN R. J. E1 mundo de las matematicas. v. 3. Traduccion: César Villazón. Barcelona: Ediciones Grijalbo, 1968. p. 86-101.

NASCIMENTO, Gabriella. Arte na Primeira Guerra Mundial. Postado no blog do grupodehistoria3012017 no dia 28 de março de 2017 e no link:

<https://memoprimeiraguerramundial.wordpress.com/2017/03/28/arte-na-primeiraguerra-mundial/>. Acesso em: 15 maio 2020

NEWMAN R. James. El mundo de las matematicas. v. 3. Traduccion: César Villazón. Barcelona: Ediciones Grijalbo, 1968.

NIETSZCHE, Friedrich. Beyond Good and Evil: prelude to the philosophy of the future. Translated by Judith Norman. New York: Cambridge University Press, 2002.

OLIVEIRA, Leonardo D. Na canção popular, presença da Antropofagia? Texto postado no Blog “OUTRASPALAVRAS” em 16/11/2014. Disponível em: $<\underline{\text { https://outraspalavras.net/poeticas/na-cancao-popular-presenca-da-antropofagia/). }}$ Acesso em: 30 maio 2020

PALMER, Tony. Tony Palmer's 100 ${ }^{\text {th }}$ Anniversary film about Britten Nocturne. DVD package design: Sharon Smart. Isolde Films \& Firefly Entertainment Ltd, 2013.

PANEK, Bernadette. Mallarmé, Magritte, Broodthaers: jogos entre palavra, imagem e objeto. ARS, São Paulo, v. 4, n. 8, 2006, p. 102-111. Disponível no site seguinte: (http://www.scielo.br/pdf/ars/v4n8/10.pdf). Acesso em: 30 maio 2020

PAULA, Carlos F. Aritmética Comercial. São Paulo: Companhia Editora Nacional, 1943.

PENHA, Davi M. @ Inverno em Saturno: a gravidade que é a poesia. Fortaleza: CeNe Editora, 2018.

POINCARÉ, Henri. El azar. In: NEWMAN R. J. El mundo de las matematicas. v. 3. Traduccion: César Villazón. Barcelona: Ediciones Grijalbo, 1968. p. 68-82.

ROOB, Alexander. Alquimia \& Misticismo. Tradução Tersa Curvelo. Portugal: Publicações e Artes Gráficas Lda, 2006. 
ROVIRA, Bibiana. Tarô egípcio kier: conhecimento iniciático do livro de Thoth: baseado no simbolismo, na mitologia e nas lendas do Egito. Tradução Euclides Luiz Calloni, Cleusa Margô Wosgrau. São Paulo: Pensamento, 2013.

SACCO, Joe. The Great War. July I, 1916. The First Day of the Battle of the Somme; An Illustrated Panorama. New York: W.W. Norton, 2013.

SANTIÁÑEZ-TIÓ, Nil. Wittgenstein's Ethics and Modern Warfare. Canadá: Wilfrid Laurier University Press, 2018.

SOUZA, Adalberto. O.; SILVA, Ogmar. L. O manifesto literário: algumas peculiaridades do manifesto dada e do manifesto antropófago. In: CELLI: $3^{\circ}$ COLÓQUIO DE ESTUDOS LINGUÍSTICOS E LITERÁRIO, 2007, p. 1-10. Maringá, Anais... Maringá, 2009.

TAYLOR, Sue. Hans Bellmer: the anatomy of anxiety. London: The MIT Press, 2000. . Hans Bellmer in The Art Institute of Chicago: The Wandering Libido and the Hysterical Body. Chicago: The Art Institute of Chicago / Ryerson and Burnham Libraries, 2001, p. 1-25. Disponível no site seguinte:

(https://archive.artic.edu/reynolds/essays/taylor.php). Acesso em: 30 maio 2020.

TORRES, Marie-Hélène. C. Resenha da tradução de Lance de Dados de Stéphane Mallarmé por Álvaro Faleiros. TradTerm, São Paulo, v. 25, p. 303-309, jun. 2015. Disponível em: < http://www.revistas.usp.br/tradterm/index >. Acesso em: 30 maio 2020.

TURING, Alan. ¿Puede pensar una máquina? In: NEWMAN; R. J. E1 mundo de las matematicas. v. 6. Traduccion: Miguel Muntaner. Barcelona: Ediciones Grijalbo, 1969. p. 36-60.

TZARA, Tristan. Sete manifestos Dada. Tradução de José Miranda Justo. Lisboa: Hiena Editora, 1987.

WITTGENSTEIN, Ludwig. Culture and value: a selection from the posthumous remains. Edited by Georg Henrik von Wright in collaboration with Heikki Nyman. Revised edition of the text by Alois Pichler. Translated by Peter Winch. Rev. 2. ed. with English translation. UK: Blackwell Publishers Ltd, 1998.

. Philosophische Untersuchungen/Philosophical Investigations (PI).

Translated by Gertrude E.M. Anscombe, Peter M.S. Hacker, and Joachim Schulte. Rev. 4th ed./by P.M.S. Hacker and Joachim Schulte.UK: Wiley-Blackwell Publishing Ltd, 2009.

Tractatus Logico-Philosophicus. Tradução, apresentação e estudo introdutório de Luiz Henrique Lopes dos Santos. São Paulo: Editora da Universidade de São Paulo, 2010. 